INSTITUTO DE GEOCIÊNCIAS

\title{
Metamorfismo e Tectônica da Região de Alfenas- Areado-Alterosa, MG: Contribuições Da Termobarometria e Datação da Unidade Granito-Migmatito Areado
}

\section{EDUARDO LOPES JULIÃO}

Dissertação apresentada ao Programa Mineralogia e Petrologia do IGC-USP para a obtenção do título de Mestre em Ciências

\author{
Área de Concentração: Petrologia Ígnea e \\ Metamórfica
}

Orientador: Porf. Dr. Renato de Moraes

SÃO PAULO 



\title{
UNIVERSIDADE DE SÃO PAULO \\ INSTITUTO DE GEOCIÊNCIAS
}

"Metamorfismo e Tectônica da Região de Alfenas-AreadoAlterosa, MG: Contribuições Da Termobarometria e Datação da Unidade Granito-Migmatito Areado"

\section{EDUARDO LOPES JULIÃO}

Orientador: Prof. Dr. Renato de Moraes

\author{
Dissertação de Mestrado \\ № 881
}

COMISSÃO JULGADORA

Dr. Renato de Moraes

Dr. Claudio de Morisson Valeriano

Dr. Maria Emilia Schutesky Della Giustina

SÃO PAULO

2021 

Autorizo a reprodução e divulgação total ou parcial deste trabalho, por qualquer meio convencional ou eletrônico, para fins de estudo e pesquisa, desde que citada a fonte.

Serviço de Biblioteca e Documentação do IGc/USP

Ficha catalográfica gerada automaticamente com dados fornecidos pelo(a) autor(a) via programa desenvolvido pela Seção Técnica de Informática do ICMC/USP

Bibliotecários responsáveis pela estrutura de catalogação da publicação: Sonia Regina Yole Guerra - CRB-8/4208 | Anderson de Santana - CRB-8/6658

Lopes Julião, Eduardo

Metamorfismo e Tectônica da Região de AlfenasAreado-Alterosa, MG: Contribuições Da

Termobarometria e Datação da Unidade Granito-

Migmatito Areado / Eduardo Lopes Julião; orientador

Renato de Moraes. -- São Paulo, 2021.

$114 \mathrm{p}$.

Dissertação (Mestrado - Programa de Pós-Graduação em Mineralogia e Petrologia) -- Instituto de Geociências, Universidade de São Paulo, 2021.

1. Petrologia Metamórfica. 2. Geologia Estrutural. 3. Datação Geológica. 4.

Geotermobarometria. I. de Moraes, Renato, orient.

II. Título. 

"The known is finite, the unknown infinite; intellectually we stand on an islet in the midst of an illimitable ocean of inexplicability. Our business in every generation is to reclaim a little more land, to add something to the extent and the solidity of our possessions."

T.H. Huxley, 1887

"The Cosmos is all that is or was or ever will be"

Carl Sagan, Cosmos, 1980

Dedicated to my uncle Narciso Benini

Which was the grandfather that l've never had And unfortunately another victim of the Covid-19 


\section{Acknowledgments}

The period of this research has been one of the most challenging of all my life. It's already started with a depression diagnosis, then lots of changes in my personal life that became big obstacles to face, like moving twice, working 60 hours per week, and dealing with isolation caused by the pandemic were some of those challenges, and with that, the acknowledgments turns an important part of this dissertation to thank everyone that helped me to achieve this goal.

First, I would like to thank my tutor, Renato de Moraes, for all the patience and empathy with my situation and all the assist to make the article become a reality. I am really grateful for all the assistance you gave along all these years, which I believe wasn't easy since my learning process is slow. I would like to thank the other co-authors of the article, Frederico Meira Faleiros, Rafael Gonçalves da Motta, Francy Roxana do Valle and Leonardo Brenguere Leão Lopes for their contribution to the research. I also acknowledge the contribution of José Vinícius Martins and Sandra Andrade from NAP Geoanalítica for their assistance with LA-ICPMS analysis. We also appreciated the aid from Kei Sato on the SHRIMP proceedings; without your help, many analytical problems would have happened.

I express my gratitude to my parents, Sonia Maria Lopes and Anezio Julião, for all their support, especially after I decided to leave my job to take care of my mental health. And in that sense, I would also like to thank Ana Lidia Jacintho Delgado for being my company in both bright and dark times, you have entered my life in my worst moment and I can only thank you for staying by my side this whole time.

I would like to thank the true friends who have welcomed me even after my breakdown. To my friends since high school and who are on my side until now, Caio Emmerick (and Thais Emmerick, which were not from school, but fits entirely in this group), Nathalie Zago, Renata Roitman, and Yorran Lee. To the Mocó Research Group, which is composed of Lucas Martins Lino Aguiar dos Santos, Francy Roxana do Valle, Rafael Casati, and Daniel do Valle, Viviana Monsalve Hernandéz, Lizeth Hernandez Tasco, Howardinne Queiroz, and, most importantly, Fernanda Souto, who has been my confidant, even when we were supposed to have English classes.

Also, I need to thank Beatriz Reis, my ex psychologist for all the assistance and comprehension with my decision about the therapy, even with all the difficulties financially and with timetables. And, to substitute my therapy, I have started a Twitch channel and I also would like to remember all people that gave me support, both technologically and mentally, Rachel (Pinkysaura), Zeus and Mylena (Fliperama do Olimpo), Roger (gabirueitz), Bárbara (BabiMJ), Gabriela (gabbylansa), Thiago (th1ko) and Eduardo (crazycorvo). 
Last but not least I would like to thank FAPESP (projects 13/04007-0, 16/22627-3, and 18/10012-0), Cnpq, and CAPES for the financial support. 



\section{ABSTRACT}

Rocks from the Southern Brasilia Orogen basement occur between Alfenas and Areado, MG, Brazil, here called Areado Granite-Migmatite Unit. This unit is composed of garnet meta-syenogranite, hornblende-garnet metatexite, and biotite stromatic diatexite with different degrees of partial melting. Even with many geological maps, no detailed work has been done in this area to understand its geotectonic meaning or the complex pattern of metamorphism, partial melting, and deformation. This study characterizes the Areado Granite-Migmatite Unit and unravels the reason for a different pattern of deformation and partial melting of this unit and its geological and tectonic context. Petrography associated with modal analysis, structural data, quartz C-axis analysis, zircon dating in ICP-MC-MS, and trace elements chemical analysis in quartz and titanite to determine metamorphic, partial melting, and deformation evolution were used as tools in this investigation. The garnet meta-syenogranite has a crystallization age of $2069 \pm 5$ Ma which indicates that this rock was generated in the last stages of the Mineiro Belt. This unit is the protolith of the migmatites, which is inferred for field observation and accessory minerals comparison. Lower intercepts from zircon indicate a metamorphic age between $671 \pm 58$ and $657 \pm 40$ Ma. Melt crystallization ages are inferred between 621 and 604Ma. Water influx and deformation during metamorphism are the cause of different rates of partial melt. The big variation in the proportion of alkali feldspar and plagioclase occurs as an effect of melting in the presence of water, together with segregation and melt loss processes. Quartz c-axis thermometer yielded deformation temperatures of 766-892 ${ }^{\circ} \mathrm{C}$ and another lowtemperature pulse between $613-714^{\circ} \mathrm{C}$, both between 11.5-15 kbar. Those values match the $\mathrm{Zr}$-in-titanite thermobarometer data, which is $786-815^{\circ} \mathrm{C}$ for hightemperature crystals and $667-708^{\circ} \mathrm{C}$ for low-temperature titanite. Although these methods have given robust results, several issues must be assessed on these thermobarometers before their application. These data indicate a deformationalmetamorphic event of high temperature, associated with partial melting before the Três Pontas-Varginha thrust. Thus, the Areado Granite-migmatite Unit should be considered as part of the Southern Brasilia Orogen in later studies. 



\section{Resumo}

Rochas do embasamento Orógeno Sul de Brasília ocorrem entre Alfenas e Areado, MG, Brasil, aqui denominadas Unidade Granito-Migmatito Areado. Esta unidade é composta por um meta-sienogranito, um granada-hornblenda metatexito e um biotita diatexito estromático com diferentes graus de fusão parcial. Mesmo com muitos mapas geológicos, nenhum trabalho detalhado foi feito nesta área para entender seu significado geotectônico ou o padrão complexo de metamorfismo, fusão parcial e deformação. Este estudo caracteriza a Unidade Granito-Migmatita Areado e desvenda a razão de um diferente padrão de deformação e fusão parcial desta unidade e seu contexto geológico e tectônico. Petrografia associada à análise modal, dados estruturais, análise do eixo $\mathrm{c}$ de quartzo, datação de zircão em ICP-MC-MS e análise química de elementos traço em quartzo e titanita foram utilizados para determinar evolução metamórfica, fusão parcial e deformação foram utilizadas como ferramentas nesta investigação. O granada meta-sienogranito possui idade de cristalização de $2069 \pm 5 \mathrm{Ma}$, o que indica que essa rocha foi gerada nos últimos estágios do Cinturão Mineiro. Esta unidade é o protólito dos migmatitos, baseado nas observações de campo e comparação de minerais acessórios. Interceptos inferiores da Concordia e idades de borda de zircão indicam uma idade metamórfica entre 671 \pm 58 e $657 \pm 40 \mathrm{Ma}$. As idades de cristalização por fusão são inferidas entre 621 e $604 \mathrm{Ma}$. O influxo de água associada à deformação durante o metamorfismo são as causas de diferentes taxas de fusão parcial. A grande variação na proporção de feldspato alcalino e plagioclásio ocorre como efeito da fusão na presença de água, juntamente com processos de segregação e perda de derretimento. O termômetro de eixo-c de quartzo gerou temperaturas de deformação de $766-892^{\circ} \mathrm{C}$ e outro pulso de baixa temperatura entre $613-714^{\circ} \mathrm{C}$, ambos entre $11,5-15$ kbar. Esses valores correspondem aos dados do termobarômetro de Zr-em-titanita, que é $786-815^{\circ} \mathrm{C}$ para cristais de alta temperatura e $667-708^{\circ} \mathrm{C}$ para titanita de baixa temperatura. Embora esses métodos tenham dado resultados robustos, existem várias questões que devem ser avaliadas nesses termobarômetros antes de sua aplicação. Esses dados indicam um evento deformacional-metamórfico de alta temperatura, associado ao derretimento parcial antes do empuxo Três Pontas-Varginha. Assim, a Unidade Granito-migmatito Areado deve ser considerada parte do Orógeno Brasília Sul em estudos posteriores. 



\section{Summary}

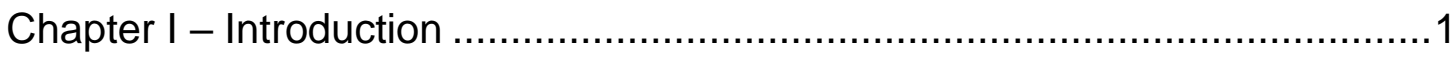

I.1 Dissertation presentation ..................................................................

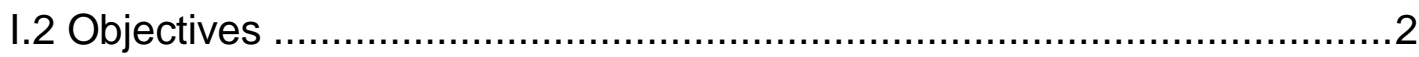

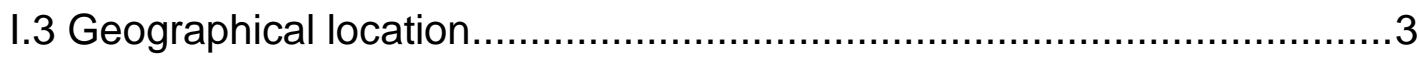

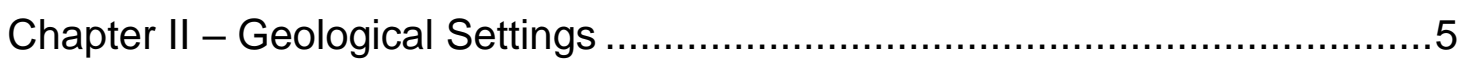

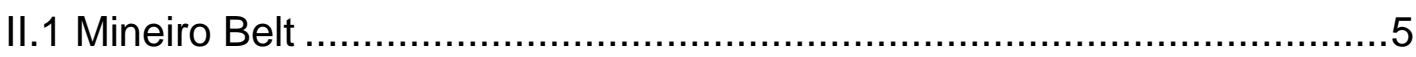

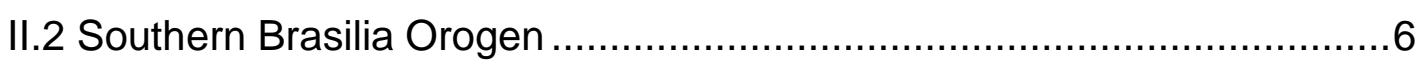

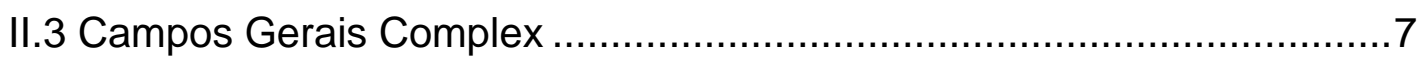

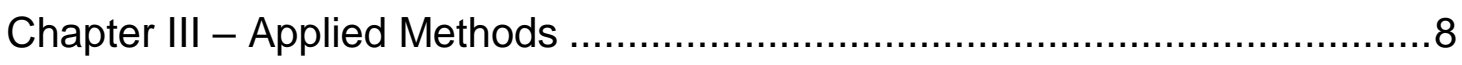

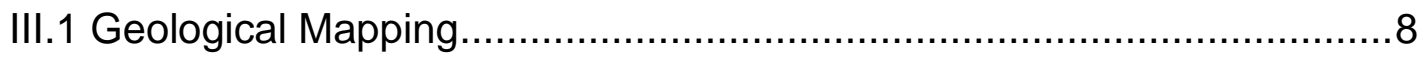

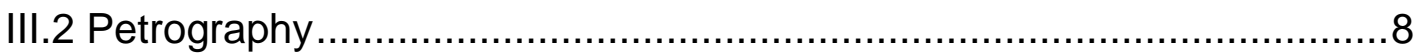

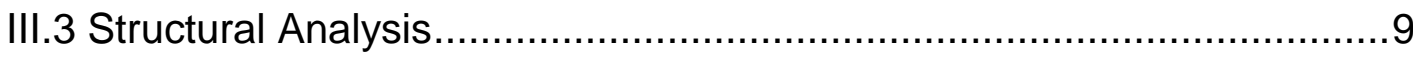

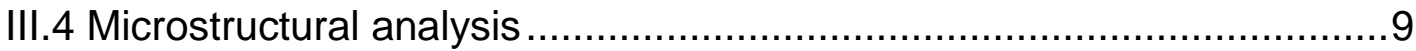

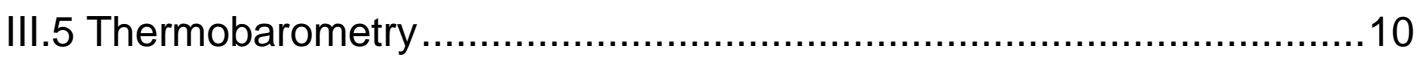

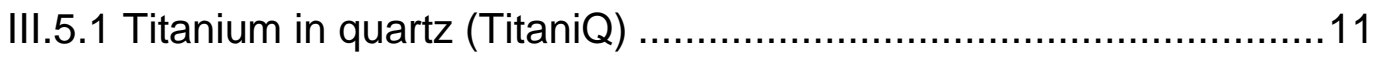

III.5.2 Zirconium in titanite (Zr-in-Tit) ..............................................12

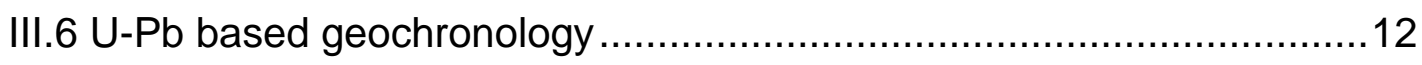

Chapter IV - Results .......................................................................... 14

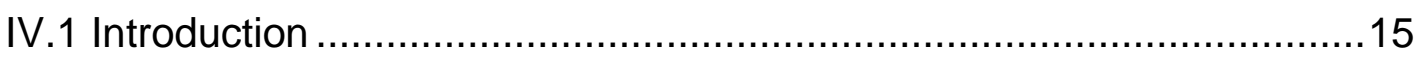

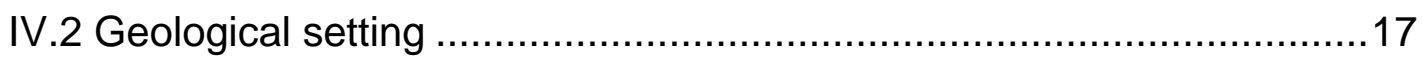

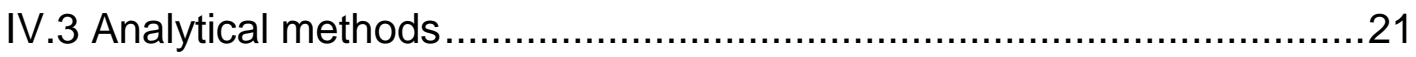

IV.4 The Areado Granite-Migmatite Unit .................................................23

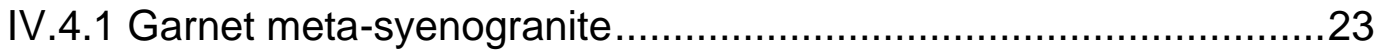

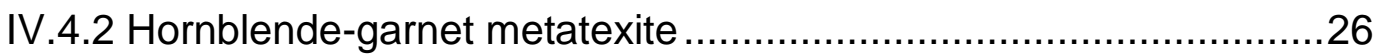

IV.4.3 Biotite stromatic diatexite........................................................ 


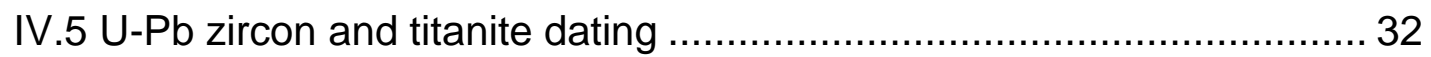

IV.6 Quartz and titanite in situ analysis and thermobarometry.................... 34

IV.7 Main structures and quartz c-axis based thermometry ...................... 37

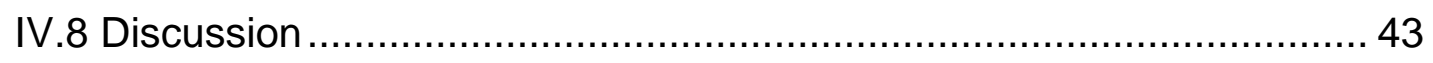

IV.8.1 Physical controls of partial melting and metamorphism ................ 43

IV.8.2 Structural evolution and thermobarometry ................................ 48

IV.83 Geological history and tectonic evolution of the Areado Unit magmatism and metamorphism ............................................................ 51

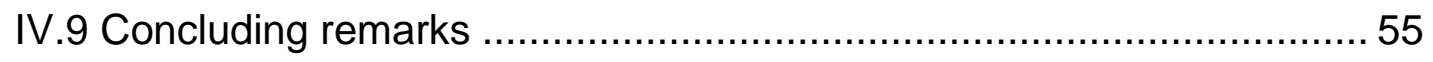

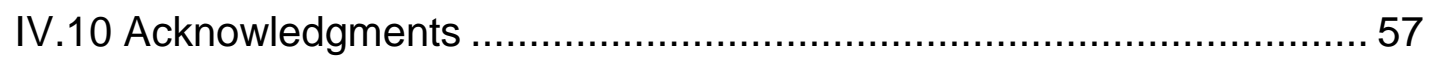

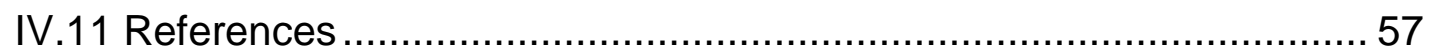

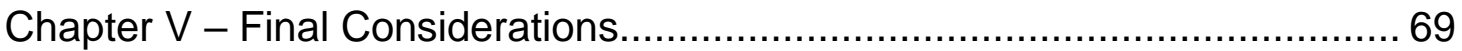

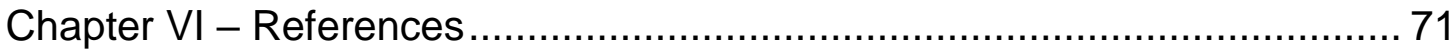




\section{Chapter I - Introduction}

The Southern Brasilia Orogen has been the subject of many academic researches (e.g. Fuck et al., 1994; Brito-Neves et al., 1999; Campos Neto, 2000; Trouw et al., 2000), however, there are several regions inside this tectonic framework and still need a detailed approach to fully understand its evolution. It is composed of nappe systems which involve rocks from a magmatic arc (Socorro-Guaxupé Nappe), and rocks associated with the magmatic arc basins (Andrelândia Nappe system) and passive margins (Carrancas and Lima Duarte Nappe systems). All these systems were subjected to regional metamorphism from green schist to granulite facies (Campos Neto, 2000; Trouw et al., 2000; Campos Neto et al. 2010, 2011).

At the northwest of this structure, the nappe thrusts a group of metagranitic rocks that went through partial melting, which here are denominated Areado Granite-migmatite unit. This area has been considered as part of the Campos Gerais Complex (Artur, 1988) which comprehends an intensely reworked unit during different tectonic cycles and has a huge lithological variety (Cavalcante et al. 1979) but no other detailed work has been made on the region to define the correct tectonic framework of the migmatites.

Despite the historical doubt, the Areado Granite-migmatite Unit presents a very complex petrological situation. In regional metamorphism, geologists observed the effect of the same pressure and temperature on rocks of a big area, however, the migmatites show different rates of partial melt and deformation inside a small area, which raises the question about the melting process that affected the area. Thus, this research shows data to unravel the geological history and petrological evolution that involved the Areado Granite-Migmatite Unit

\section{I.1 Dissertation presentation}

In the last few years, the Institute of Geosciences has suggested the students publish articles during the academic period and include them in their dissertations or thesis. This way of presentation presents a big advantage in the sense of making the dissertation more compact with the same academic quality, and the use of published articles shows an interesting approach since the articles 
have already been peer-assessed, which guarantees a high-quality text. With this idea, this dissertation follows the structure below:

Chapter I - Introduction: This section will introduce the subject of the research, along with the objectives, justification, and the location of the studied area.

Chapter II - Geological Setting: This chapter describes in bigger detail the geological context than presented in the article and the earlier studies of the Areado granite-migmatite unit.

Chapter III - Analytical Methods: This section presents the methodology used to achieve a good quality result, together with the scientific background of the methods, with a major focus on thermobarometry.

Chapter IV - Results: This chapter exhibits the published article "The role of deformation-assisted by water influx on partial melting of a granite protolith, and its role in the evolution of southwestern São Francisco Craton margin, Brazil” accepted on the Journal of South America Earth Sciences on October 17th 2021. It shows the results and a major discussion about the data obtained from the Areado granite-migmatite unit.

Chapter V - Concluding Remarks: It presents a summary of the discussion presented in the article and a reflection about the use of the methods on the samples.

Chapter VI - References: A list of all citations used in this volume, with exception of chapter IV.

\section{I.2 Objectives}

The project covers structural, petrological, and geochronological aspects of the Areado Granite-migmatite Unit to define the relation of the unit with other rocks around it, the connection it has with the geological evolution of the area, and understand the metamorphic process that affected these rocks and caused a big difference in melting fraction. Thus, the objectives of this work are: 
- Characterize petrologically the main lithotypes present in the Areado Granite-migmatite Unit and understand the relation between them.

- Analyze the structural variation, together with geological mapping to establish the connection of this unit with other units around it.

- Define the proper thermobarometers for these rocks and find the metamorphic peak of the rocks.

- Date both the crystallization age of the metagranite and the partial melting age to generate a geological model for the evolution of the unit.

- Integrate all data and clarify the tectonic framework that the Areado Granite-migmatite Unit is inserted and the metamorphic process that generated such different partial melting rates.

\section{I.3 Geographical location}

The studied area is located between the cities of Alfenas and Areado, in the southern region of Minas Gerais. The main accesses to the area are the MG491 that connects the cities to Varginha, the Fernão Dias highway (BR-381), and the roads MG-179 and MG-369, which pass between Pouso Alegre and Alfenas (Fig. 1) 


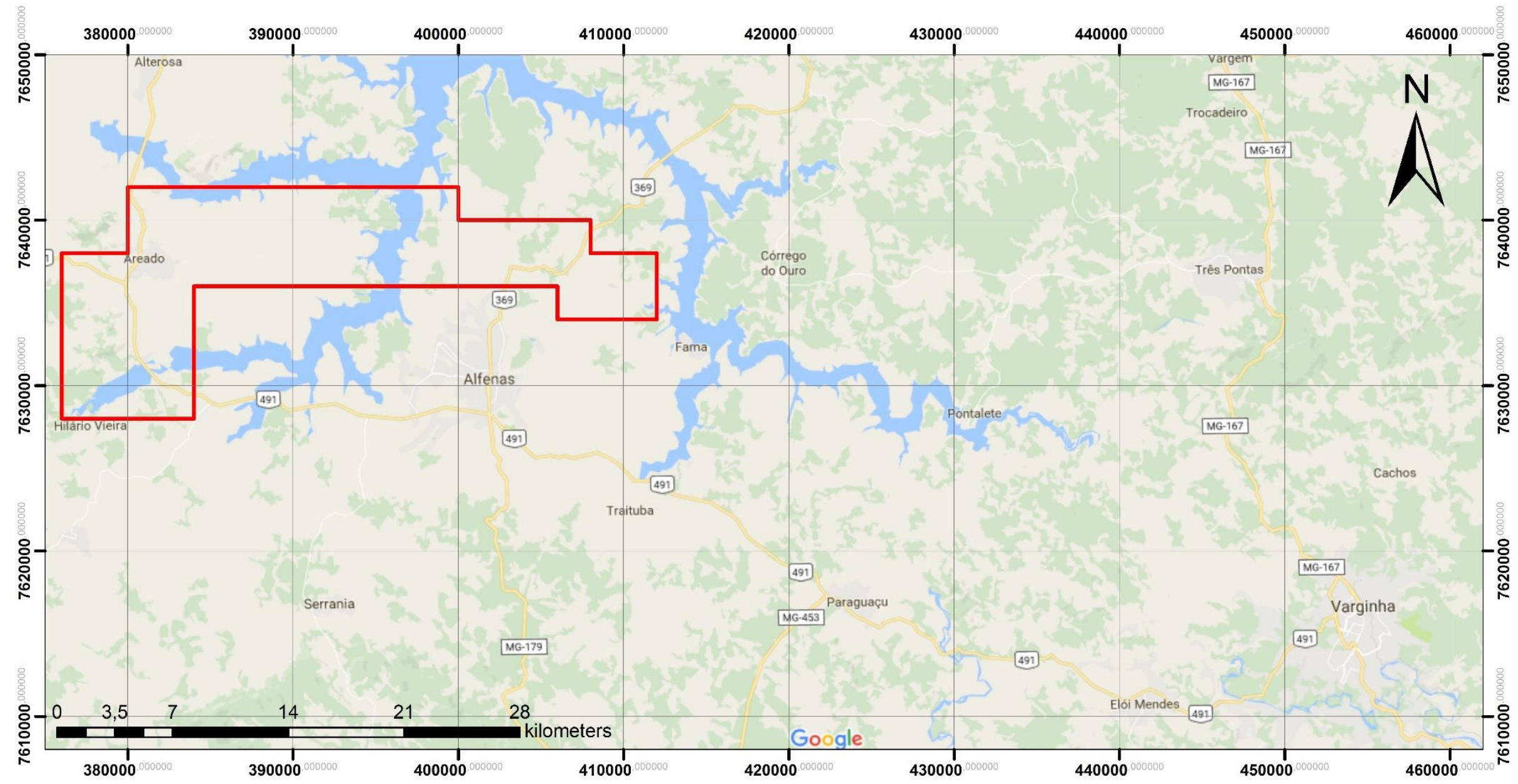

Figure 1 - Geographical localization of the studied area and the main roads to access it 


\section{Chapter II - Geological Settings}

The rocks investigated are located at the southernmost part of the Brasilia Orogen, a neoproterozoic fold belt, which borders the São Francisco Craton at its west and southwest margins. The São Francisco Craton is formed by greenstone belts, granites, gneisses, and migmatites of the archean and paleoproterozoic ages. At the craton eastern border, the so-called Mineiro Belt crops out, in which rocks formed or affected by a paleoproterozoic orogeny occur. As mentioned earlier, in a structural window, to west, between the Passos, to the north, and the Andrelândia Nappe Systems, to the south, there are old rocks, also of archean and paleoproterozoic ages, neither attributed to the São Francisco Craton nor to Mineiro Belt. As they were partially affected by this neoproterozoic orogeny, and so, they were related to the older Paramirim Craton.

\section{II.1 Mineiro Belt}

The Mineiro Belt is situated at the southeastern border of the São Francisco Craton, which is limited by the Jeceaba-Bom Sucesso and Congonhas-Itaverava lineaments (Campos and Carneiro, 2008; Ávila et al., 2010; Teixeira et al., 2015) and the Lenheiro shear zone (Teixeira and Figueiredo, 1991). The stratigraphy of the Mineiro Belt exhibits paleoproterozoic orthogneisses and igneous bodies associated with coeval supracrustal units (Alkmim and Teixeira, 2017). Orthogneisses and granites are of granite, granodiorite, and trondhjemite composition, with metaluminous to peraluminous and calc-alkaline affinity (e.g. Ávila et al., 2010, 2014; Teixeira et al., 2015), and present four different orogenic groups, based on isotopic and geochemical data, such as 2.47-2.41, 2.36-2.33, 2.23-2.20 and 2.17-2.09 Ga (Teixeira et al., 2017). The formation of these rocks is related to a long-term magmatic accretion, associated with oceanic subduction slab (Noce et al., 2000). Sm-Nd whole rock and Lu-Hf in zircon data attest the juvenile source of the Mineiro Belt magmatism (e.g. Ávila et al., 2010, 2014; Teixeira et al., 2015; Moreira et al., 2018). So far, the youngest recognized plutonic rocks that are attributed to the final 
amalgamation involved in the formation of Mineiro Belt date within the range of 2.17 and 2.10 Ga (Barbosa et al., 2015) and are related to an accretionary orogeny (Teixeira et al., 2015). These granites are separated into two groups, the first corresponds to rocks formed between 2.17-2.15 Ga and generated by partial melting of LREE enriched MORB and with crustal assimilation. Meanwhile, the second group presents ages between 2.14-2.10 Ga, they present geochemical similarities to metadiorites, depleted in $\mathrm{Ti}, \mathrm{Nb}$, and $\mathrm{P}$, formed by fractional crystallization and contamination with crustal material (Barbosa et al., 2015).

\section{II.2 Southern Brasilia Orogen}

The Brasilia Orogen (Fuck et al., 1994; Dardenne, 2000) is part of the Tocantins Province (Almeida, 1981) and it is interpreted as the result of the collision of the Central Goiás and Paranapanema blocks against the San Franciscan Plate (Brito Neves et al., 1999; Campos Neto, 2000; Trouw et al., 2000). This orogen is segmented into three domains (Fuck et al., 2017): (i) the External domain, which comprises cratonic rocks and its undeformed cover; (ii) the Internal domain, which represents the metamorphic area of the orogen; and (iii) the Goias Magmatic Arc domain (see Fig 2, Chapter IV). The metamorphic grade increases from the External towards the Internal domain (Fuck et al., 2017), reaching ultra-high temperature metamorphic conditions (e.g. Moraes et al., 2002). The metamorphic event is neoproterozoic (e.g. Pimentel, 2016).

The Southernmost Brasilia Orogen denotes a thick-skinned nappe system, with a $300 \mathrm{~km}$ displacement (Brito-Neves et al., 1999; Campos Neto, 2000). It was divided into a domain of passive margin related to the San Franciscan paleocontinent with basement rocks (e.g. Cioffi et al., 2016; Peternel et al., 2005), along with metasedimentary rocks, that corresponds to the São Vicente Complex, Carrancas and Lima Duarte Nappe Systems (e.g. Trouw et al., 2008; Westin et al., 2016; Westin and Campos Neto, 2013). The other domain recalls to the active margin of the Paranapanema with a metasedimentary unit from Andrelândia Nappe System (e.g. Campos Neto et al., 2011, 2010), together with magmatic arc unit, the Socorro-Guaxupé Nappe (Campos Neto, 2000; Campos Neto and Caby, 2000; Janasi, 2002). 
Dating zircon crystals from rocks of the Socorro-Guaxupé Nappe, with the $\mathrm{U}-\mathrm{Pb}$ method, reveal the age of arc magmatism to be before the collision stage, ca. 730-640 Ma (Rocha et al., 2017, 2018). Metamorphic conditions are extreme, with $940^{\circ} \mathrm{C}$ at $11 \mathrm{kbar}$, in the granulites at the base of the nappe (Moraes et al., 2015; Rocha et al., 2018), and diatexites at their top (Rocha et al., 2017). The age of this UHT metamorphism is ca. $630-625 \mathrm{Ma}$, proving to be syn-collisional (Campos Neto et al., 2004; Rocha et al., 2017, 2018), whereas zircon crystals from leucosome of granulites and diatexites crystallized in a considerable interval, from 612 to $600 \mathrm{Ma}$ (Rocha et al., 2017, 2018; Tedeschi et al., 2018). Below these UHT granulites, the Três Pontas-Varginha Nappe occur, and it comprises high-pressure kyanite-garnet granulite, associated with subordinate garnet mafic granulite, and calc-silicate rocks (Trouw and Castro, 1996; Campos Neto, 2000; Campos Neto and Caby, 2000; Trouw et al., 2000; Garcia and Campos Neto, 2003; Reno et al., 2009; Motta and Moraes, 2017). Although several authors investigated the $P$ - $T$ conditions of metamorphism, the most recent calculations combine $\mathrm{Zr}$-in-rutile and Ti-in-quartz data and produced 850 ${ }^{\circ} \mathrm{C}$ and minimum pressures of $15 \mathrm{kbar}$ (Martinez, 2015).

\section{II.3 Campos Gerais Complex}

The Campos Gerais Complex is frequently reported as a "complex unit, intensively recycled and crustally reworked in successive tectonic cycles" (e.g. Cavalcante et al., 1979; Artur, 1988). The Campos Gerais Complex is composed of a variety of rocks: gneiss and migmatites of granodiorite to tonalite compositions, with lenses of metamafic and metaultramafic rocks, schists, quartzite, and intrusive granite bodies (Cavalcante et al., 1977; Artur, 1988; Szabó, 1989). This unit has been divided into North and South Domains (e.g. Morales et al., 1983; Schrank et al., 1990; Szabó, 1996). The first is composed of an autochthonous terrane with granite-greenstone belt characteristics like the Morro do Ferro Greenstone Belt sequence (Teixeira et al., 1987; Szabó, 1996). Meanwhile, the second domain comprises paragneisses, and intercalated sequences of metasedimentary rocks with amphibolites and metaultramafic units (e.g. Morales et al., 1983; Szabó, 1996). Recently, it was proposed that the Campos Gerais Complex should be restricted to the granites and orthogneisses 
from the North Domain (Turbay et al., 2008). It is also recognized that intrusive paleoproterozoic metagranites crosscut the rocks of the Campos Gerais Complex (Turbay and Valeriano, 2012).

The rock investigated in the present research has not yet been well mapped or properly separated in any regional map, in some of them it is mapped as part of the Andrelânida Nappe System (Campos Neto, 2000), but in some others, it is considered as part of the Campos Gerais Complex (e.g. Campos Neto et al., 2004; Heilbron et al., 2017). This data corroborates with observations made by Turbay et al. (2008). The age of metamorphism of the Campos Gerais Complex is $2.9 \mathrm{Ga}$ (Wernick et al., 1981; Teixeira et al., 1989) . In recent work, the crystallization ages for the protoliths of some of these orthogneisses have been determined as $2.9 \mathrm{Ga}$, using U-Pb dating in zircon, with partial melting and metamorphism at $2.6 \mathrm{Ga}$, and possibly with the presence of some primitive crust, even older, of ages 3.2-3.6 Ga (Valeriano et al., 2006).

\section{Chapter III - Applied Methods}

\section{III.1 Geological Mapping}

A regional geological reconnaissance has been made in order to define the structural relation between the migmatitic units of the area. Most outcrops of the area are presented as slabs for the diatexite unit, and blocks for the other units, with the exception of the Areado quarry where the meta-syenogranite lithotype is present. To achieve a better result, we made cross-sections with structural data measurements and generated a Geological Map using ArcMap 10.1 software.

\section{III.2 Petrography}

During the geological mapping stage, several samples were acquired to obtain more information about the mineralogical, structural, and textual characteristics of the rocks involved in this project. To do so, an Olympus BXP40 microscope with an Infinity One camera coupled was used in the Optical 
Microscopic Laboratory from the Núcleo de Apoio à Pesquisa Geoanalítica (NAP) of IGc-USP. For the modal analysis, an Olympus U-FMP chariot was used to count minerals. Since most of the samples presented coarse crystals, we utilized a $1 \mathrm{~mm}$ square grid for counting, with the minimum amount of 600 points counted in each thin section. In addition, for units with megacrysts, photographs were used to count the proportion of megacryst and groundmass. This was made with a 20×30 grid in Corel Draw X5 program.

\section{III.3 Structural Analysis}

A detailed structure description was made along with the collection of structural data using a Clar-type compass. These structural data were loaded on Stereonet software (v. 9.5.1) and projected on a south hemisphere SchmidtLambert stereogram to look for a correlation between the structures. The crosssections were generated using the plotted structures on the map, no vertical exaggeration was used on them.

\section{III.4 Microstructural analysis}

Mineral microstructures encountered in deformed rocks are usually associated with the preferential orientation of the main structure. Many mechanisms are responsible for the formation of oriented crystals, however, in the case of the same crystal shape, like quartz, the main process is the dislocation creep, which rotates the grains due to the change of habit and the interaction with neighbor minerals (Paschier \& Trouw, 2005). The variation of sliding in relation to the crystalline structure of quartz is dependent on the temperature. In lower temperatures, the migration tends to follow the <a> crystallographic axis, while the crystals tend to dislocate towards the $<\mathrm{c}>$ crystallographic axis at higher temperatures (Kruhl, 1986, 1996). In the case of quartz grains, the increase of temperature also alters the recrystallization textures and the way that the grains dislocate, from bulging (BLG), to Sub-grain rotation (SGR) and grain boundary migration (GBM) respectively (Stipp et al., 2002b). 
The c-axis quartz thermometer was created by Kruhl (1998) that demonstrated the correlation of the spatial position of the quartz $<c>$ axis with the deformation temperature. The quantification is made using the distribution of the $<\mathrm{C}>$ axis data on the stereogram and measuring the opening angle between the major concentrations. The author used both natural and experimental data to calibrate this thermometer and estimated a $50^{\circ} \mathrm{C}$ error margin.

Although it is a practical method, some factors can influence the temperature calculation. Both strain rate and water presence can cause a variation of the data. In addition to it, divergences in the way of the opening angle measurements can also interfere with the results (Law, 2014). Faleiros et al. (2016) raise the importance of the pressure as a factor of angle variation generated a calibration based on opening angle, pressure and temperature:

$$
T(\stackrel{\circ}{\circ} C)=410.44 \ln O A+14.22 P(\text { kbar })-1272
$$

$\mathrm{OA}$ stands for the $\mathrm{C}$-axis opening angle, $\mathrm{P}$ for pressure, and $\mathrm{T}$ for temperature. This calibration also extended the thermometer interval to rocks from granulite facies and ultra-high temperatures, and it also presents an error margin of $50^{\circ} \mathrm{C}$.

The Faleiros et al. (2016) calibration was used in this work to estimate the deformation temperature of the studied samples. A Zeiss Ortholux microscope with a four-axis Leinz Wetzlar universal-stage from the Laboratório de Óptico (IGc-USP) was used to obtain the c-axis measurements, and the data were treated on the Stereo 32 software to obtain the grindles and the opening angles. The calculation was made on a spreadsheet in Microsoft Excel 2013.

\section{III.5 Thermobarometry}

Two thin sections and one polished block were used to analyze the trace elements in titanite and quartz in a quadrupole ICP-MS ICAP Q - Thermo Scientific model coupled with a 213 A/F - New Wave Laser Ablation Sampler. During the procedure, Heraeus glasses were used as intern standard, for quality control and calibration of the equipment. Data was inserted in Glitter (v4.4.4) to 
quantify the amount of trace elements; to do so, a stoichiometric proportion obtained from Deer et al. (1994) was used to calibrate the estimative. This data was used with different thermometers, which are explained below.

\section{III.5.1 Titanium in quartz (TitaniQ)}

Titanium is commonly found in igneous and metamorphic quartz crystals, controlled by a coupled substitution reaction between $\mathrm{Si}, \mathrm{Ti}$, and other cations (Wark and Watson, 2006). The diffusion of $\mathrm{Ti}$ in quartz is slower than other elements like aluminum and gallium, however, its valence facilitates the exchange. The excess of titanium inside the crystals can cause exsolution of $\mathrm{TiO} 2$ in the form of rutile needles, concentrating the element in a sector of the grain (Cherniak et al., 2007). Wark and Watson (2006) calibrated a thermometer based on synthetic samples of quartz in the presence of $\mathrm{TiO} 2$ component, between 600 to $1000^{\circ} \mathrm{C}$ and $1 \mathrm{GPa}$ pressure, with a Ti detection limit of $15 \mathrm{ppm}$. The authors considered the pressure an irrelevant fact in the calibration of TitaniQ. However, Thomas et al. (2010) calibrated o TitaniQ as a thermobarometer with synthetic analysis of quartz and rutile, and silica-saturated fluids between 700 and $940^{\circ} \mathrm{C}$ and pressures of 5 and $20 \mathrm{kbar}$ with a detection limit of $8 \mathrm{ppm}$. The calibration equation is:

$$
R T \ln X_{\mathrm{TiO}_{2}}^{\text {quartz }}=-60952+1520 T(K)-1741 P(k b a r)+R T \ln a_{\mathrm{TiO}_{2}}
$$

Where $X_{\mathrm{TiO}_{2}}^{\text {quartz }}$ represents the molar fraction of TiO2 in quartz grains, $\mathrm{T}$ is the temperature in Kelvin, $\mathrm{P}$ is pressure in kbar, and $a_{\mathrm{TiO}_{2}}$ is the activity of TiO2 on the rock. The experiments from Thomas et al. (2010) showed a great influence of the pressure on the concentration of $\mathrm{Ti}$ in quartz grains. This calibration was used in this research and the calculations were made on Microsoft Excel 2013. 


\section{III.5.2 Zirconium in titanite (Zr-in-Tit)}

Titanite is a common accessory mineral of igneous and metamorphic rocks and has a huge potential to be applied as a thermobarometer, due to its capacity for element substitution in its crystalline structure. Zirconium ( $\mathrm{Zr}$ ) usually substitutes titanium in the mineral structure. Its diffusion in titanite is considered intermediate since it is slower than lead and oxygen, but faster than rare earth elements. It also tends to preserve the formation temperature better than other elements because of its slower diffusion gradient (Cherniak, 2006).

Hayden et al. (2008) calibrated a thermobarometer based on de diffusion of $\mathrm{Zr}$ in titanite in an interval of $600-1000^{\circ} \mathrm{C}$ and up to $10 \mathrm{kbar}$, with a detection limit of $75 \mathrm{ppm}$. The formula of the calibration is:

$$
\log Z r^{\text {titanite }}=10.52-\frac{7708}{T}-960 \frac{P}{T}-\log \left(a_{\mathrm{TiO}_{2}}\right)-\log \left(a_{\mathrm{SiO}_{2}}\right)
$$

Where $\mathrm{Zr}$ ritanite is the $\mathrm{Zr}$ concentration in the titanite crystal in ppm, $\mathrm{T}$ is temperature, $\mathrm{P}$ is pressure, $a_{\mathrm{TiO}_{2}}$ and $a_{\mathrm{SiO}_{2}}$ represent the $\mathrm{TiO} 2$ and $\mathrm{SiO} 2$ activity in the system, respectively. Due to the dependence of the activities, the thermometer is perfect for the appliance on rocks that has quartz and rutile, however, granites without rutile can be tricky to use it. The authors suggest using $a_{T^{2} O_{2}}=0.6$ in that case since most granites present that activity. It is possible to use the Zr-in-titanite together with TitaniQ to constrain the pressure and temperature of a sample (Thomas et al. 2010).

\section{III.6 U-Pb based geochronology}

Dating the Areado migmatite-granite unit is essential to unravel the geological evolution of the area. As cited above, many geological maps of the region give divergent information about the geological history associated. To define the tectonic framework, associated with petrological studies, this research also abroad U-Pb dating of zircon and titanite looking for crystallization and metamorphism ages. Both zircons and titanite from the samples were separated 
using the protocol described in Loios (2004). Then, the generated samples were used in three different sessions.

One of them was conducted on a Thermo Scientific Neptune LA-MC-ICPMS and an Excimer 193nm laser from Photon Machine, at CPGeo, Institute of Geosciences, University of São Paulo to evaluate the sample ARE-04, which correspond to a non-active quarry, south of Areado, MG (23K 0379323/7631788). The second session involved another sample from the quarry (CGE-25) and other samples from the migmatites, north of Alfenas, MG (CGE-03Zr and CGE-05). This session was carried out at the Sensitive high-resolution ion microprobe (SHRIMP Ile/MC) from the Institute of Geosciences, University of São Paulo, Brazil. The last session happened on SHRIMP II at the John de Laeter Centre of Mass Spectrometry at Curtin University and evaluated U-Pb data from the sample TPR-40, which comes from an outcrop of the diatexite leucosome from Três Pontas, MG area. 


\title{
Chapter IV - Results
}

\begin{abstract}
The Areado Granite-Migmatite Unit is part of the basement from the Southern Brasilia Orogen at southwestern São Francisco Craton margin, outcropping between Alfenas and Areado regions, Minas Gerais State, Brazil. This unit is composed of garnet meta-syenogranite, hornblende-garnet metatexite, and stromatic diatexite with different degrees of partial melting. This study characterizes the garnet meta-syenogranite, its migmatitic counterparts and investigates the different patterns of deformation and partial melting involved to produce the observed migmatites within the unit. The connection between the garnet meta-syenogranite, hornblende-garnet metatexite, and biotite diatexite is inferred from field observations and assemblage of accessory minerals. Petrography associated with modal analysis, structural data, quartz c-axis analysis, zircon U-Pb (LA-MC-ICP-MS and SHRIMP) dating, as well as trace elements chemical analysis in quartz and titanite to determine metamorphic, partial melting, and deformation evolution were used as tools in this investigation. The garnet meta-syenogranite has a crystallization age of $2069.8 \pm 5 \mathrm{Ma}$. Lower intercepts from zircon indicate a metamorphic and partial melting age between $671 \pm 58$ and $657 \pm 40 \mathrm{Ma}$. Melt crystallization ages are inferred between $622 \pm$ $7 \mathrm{Ma}$ and $604 \pm 6 \mathrm{Ma}$. Different rates of partial melt are structurally connected, being higher at the base of the unit, and are related with contrasting amounts of water influx and deformation. The deformation during metamorphism/partial melting was the main cause of the differential aspect of the produced rocks. Quartz c-axis thermometer yielded deformation temperatures of $765-935^{\circ} \mathrm{C}$ and other pulses occurred between $590-715^{\circ} \mathrm{C}$, both between 11-15 kbar. Those values match the $\mathrm{Zr}$-in-titanite thermobarometer data, which is $670-710{ }^{\circ} \mathrm{C}$ for low-temperature titanite and $785-815{ }^{\circ} \mathrm{C}$ for high-temperature crystals. These data indicate that the protolith was generated at a Rhyacian late magmatic stage of the Mineiro Belt and passed by a Neoproterozoic deformational-metamorphic event of high temperature.
\end{abstract}


Keywords: metamorphism, quartz c-axis, thermobarometry, water-influx melting.

\section{IV.1 Introduction}

Regional metamorphism is associated with orogeny, resulting in the formation of mountain ranges. It comprises an increase in pressure and temperature on active margins, leading to recrystallization and metamorphism, which has as a primary characteristic feature to produce similar $P-T$ metamorphic conditions affecting a large crustal region. As the base of these mountain ranges cannot be accessed directly to be investigated, the rocks formed at these portions of the continental crust and exposed in ancient exhumated orogens are the targets to evaluate the processes acting at these sites, such as high-grade metamorphism and partial melting. They are accessed in the outcrops of metamorphic rocks, such as migmatites and granulites (e.g. Sawyer, 2008; Moraes et al., 2015).

The studies of ancient high-grade metamorphic rocks can give us clues about the evolution of the lower crust in the past. Metamorphic studies of those rocks usually investigate mineral assemblages, their composition, ages, and textures to generate a pressure-temperature-time model and show how deep the rock was in the crust and how hot it was during the metamorphic peak and along its exhumation. The models can be made by thermodynamic modeling, analysis of metamorphic minerals pair for geothermometer generation, experimental studies, or analysis of trace elements in metamorphic minerals. In addition, metamorphic textures may reveal the processes that the migmatites passed through, such as partial melting, segregation, and crystallization. These data, associated with geochronological studies can show the geological behavior of the lower crust on large orogenic belts and give a broader view from the crustal evolution of the Earth and insights of the processes happening in new orogens, such as the Alps and the Himalayas.

In Brazil, the Southern Brasília Orogen is a thick-skinned structured nappe belt, where pieces of its basement were involved and worked during its formation in the Neoproterozoic (Fuck et al., 1997; Campos Neto, 2000; Valeriano, 2017). 
These slices are observed in several levels of crustal depth offering an opportunity to investigate the processes of transformation that are imposed in the relatively cold, old and dry crust when involved in much younger orogenic events. In southwestern Minas Gerais, Archean, and Paleoproterozoic rocks crop out in the infrastructure of the Southern Brasília Orogen, some related to the Mineiro Belt, a Paleoproterozoic orogen situated at the southern edge of the São Francisco Craton (Teixeira et al., 2000).

Between the cities of Alfenas and Areado (Fig. 3), a garnet metasyenogranite, along with its metamorphic equivalents, a hornblende-garnet metatexite, and a biotite stromatic diatexite, here called the Areado GraniteMigmatite Unit, crops out as infrastructure of the uppermost portion of the Andrelândia Nappe System, one of the main metasedimentary units in the southernmost portion of the Brasília Orogen. In addition, the diatexite from this unit also appears as blocks close to Três Pontas city (see Fig. 3). Although the Areado Granite-Migmatite Unit occurs with a relatively small thickness, it spreads in a large area, a variable degree of deformation and partial melt is observed, which is not compatible with just simple variation of temperature of regional metamorphism. In addition, although several geological maps have been made in the region (e.g., Cavalcante et al., 1977; Artur, 1988; Ribeiro et al., 2014; Campos, 2015), none of them has made detailed research on this unit, which difficult the definition of its tectonic framework, petrological and geological meaning.

In the present paper, it is investigated the relationship between metamorphism, heterogeneous deformation, and variation in the degree of partial melting within the Areado Granite-Migmatite Unit, to understand how the different metamorphic products were generated in a small geographic area. The investigation is based on petrography, deformation temperatures, which were determined using c-axis quartz thermometer (Faleiros et al., 2016), metamorphic temperatures calculated using in situ analysis of trace element in quartz and titanite, using, respectively, the thermobarometers Ti-in-quartz (TitaniQ; Thomas et al., 2010) and Zr-in-titanite (Hayden et al., 2008). Also, the crystallization age of the garnet meta-syenogranite is determined using zircon crystals and LA-MCICP-MS, and the age of metamorphism and partial melting is determined with 
SHRIMP using zircon and titanite grains, to constrain its metamorphic/partial melting and crystallization ages and tectonic history.

\section{IV.2 Geological setting}

The rocks investigated in this study are located in a key geotectonic position, where Archean to Paleoproterozoic rocks associated with the southwesternmost margin of the São Francisco Craton are surrounded by rocks of the southern part of the Neoproterozoic Brasília Orogen (Fig. 2). The São Francisco Craton, which was consolidated during the Neoproterozoic, is composed of TTG rocks and greenstone belt assemblages. It crops out in southern Minas Gerais and Bahia States, being mostly covered by sedimentary rocks of Bambui or São Francisco basins (Alkmim, 1993). Its eastern border is formed by the Mineiro Belt, a Paleoproterozoic orogen constituted of several magmatic arcs (Teixeira et al., 2000). To the west of the western limit from the São Francisco Craton, in a structural window, croup out a group of high-grade rocks of tonalitic to granitic protoliths along with minor occurrences of supracrustal rocks, including greenstone belts, some of them grouped in the Campos Gerais Complex (Cavalcante et al., 1977; Morales et al., 1983; Teixeira et al., 1987; Artur, 1988; Szabó, 1989; Schrank et al., 1990; Szabó, 1996). Available zircon U-Pb data for orthogneisses indicate Archean magmatic episodes between 3.0 and $2.7 \mathrm{Ga}$, metamorphic episodes at 2.2 and $2.0 \mathrm{Ga}$, and late granitic magmatism at $1.9 \mathrm{Ga}$ (Valeriano et al., 2006; Turbay, 2010). The Campos Gerais Complex presents an E-W-trending elongated shape limited in north and south by the Passos, Andrelândia, and Três Pontas-Varginha Nappe Systems from the Brasília Orogen (Fig. 3). Although it displays the main structure parallel to these Neproterozoic nappes, no unequivocal geochronological data are supporting the interpretation that it was substantially involved in the Neoproterozoic deformation. Neoproterozoic dating in zircon grains from Campos Gerais Complex rocks is restricted to very imprecise lower intercept U-Pb ages between 650 and $510 \mathrm{Ma}$ (Turbay, 2010).

The Brasilia Orogen is interpreted as the result of the collision of the Central Goiás Massif, Paranapanema and São Francisco-Congo Plates during the 
Neoproterozoic (Fig. 3; Fuck et al., 1994; Brito Neves et al., 1999; Dardenne, 2000; Campos Neto, 2000; Trouw et al., 2000; Valeriano et al., 2004). The southern part of the orogen denotes a thick-skinned nappe system, with a 300 $\mathrm{km}$ displacement (Brito-Neves et al., 1999; Campos Neto, 2000). It consists of schists and paragneiss, along with metabasic rocks associated to passive margin setting, called the Araxá Group, in Passos Nappe (Valeriano et al., 2004; Valeriano, 2017) and Carrancas and Lima Duarte Nappe Systems (e.g., Trouw et al., 2008; Westin et al., 2016; Westin and Campos Neto, 2013). Structurally above this 


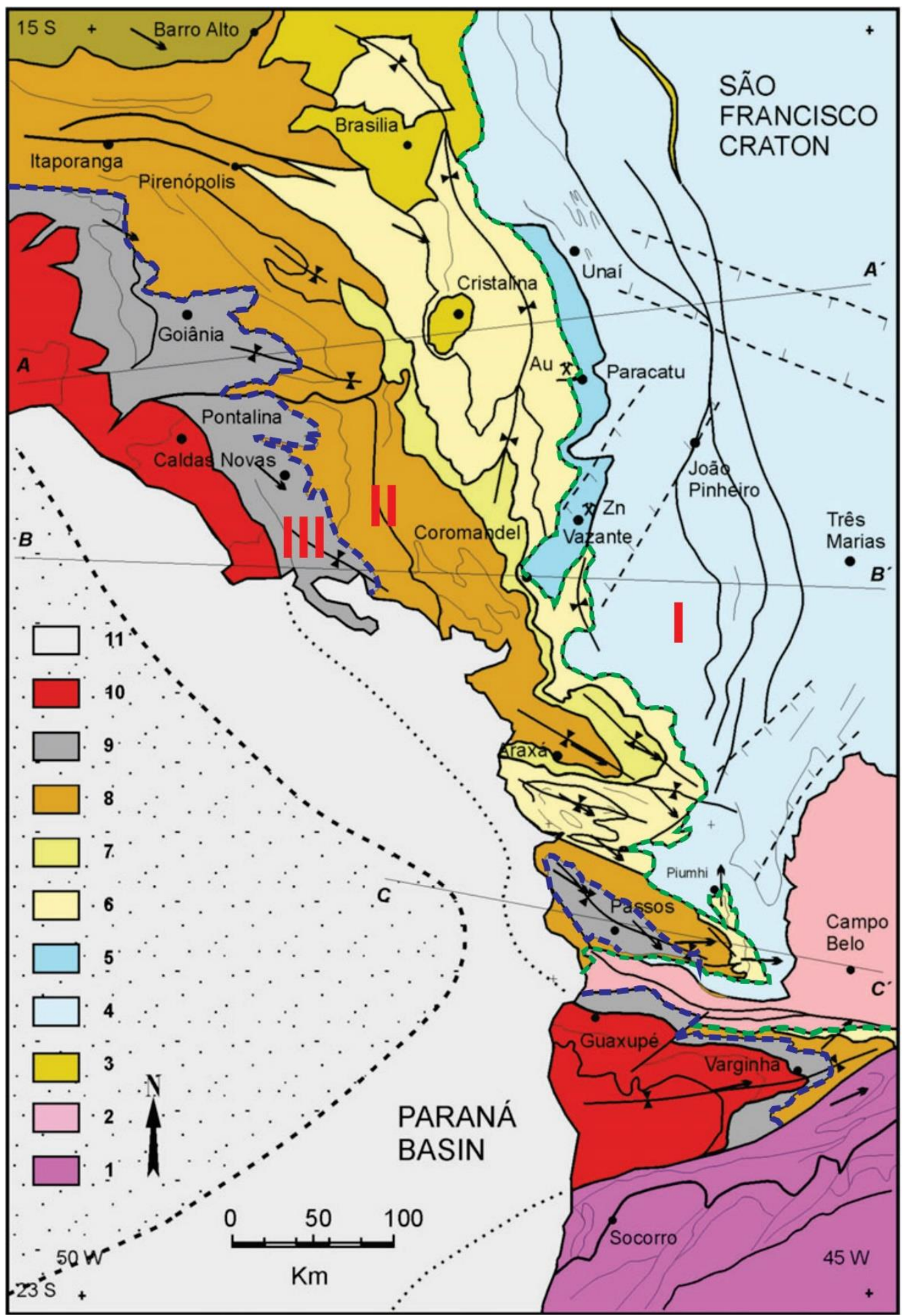

Figure 2 - Geological and tectonic map of the Southern Brasilia Orogen, associated with the southwestern margin of the Sao Francisco Craton. Dashed coloured lines separate the orogens in three domains: I- The External domain, II- The Internal Domain and III - Goiás Magmatic Arc. Keys:1-Ribeira belt; 2-São Francisco craton basement; 3-Paranoá Group; 4-Bambuí group cratonic cover; 5-Vazante Group; 6-Canastra Group; 7-lbiá Group; 8-Araxá Group; 9Araxá Group metamorphosed under granulite facies conditions; 10-Magmatic arc complexes; 11-Phanerozoic cover (Paraná Basin). In the southernmost part of the orogen, number 6, 8 and 9 are considered part of the Andrelândia Nappe system, while number 10 is called SocorroGuaxupé Nappe (e.g. Campos Neto, 2000; Campos 2010, 2011; Cioffi et al., 2016). Modified from Valeriano (2017). 


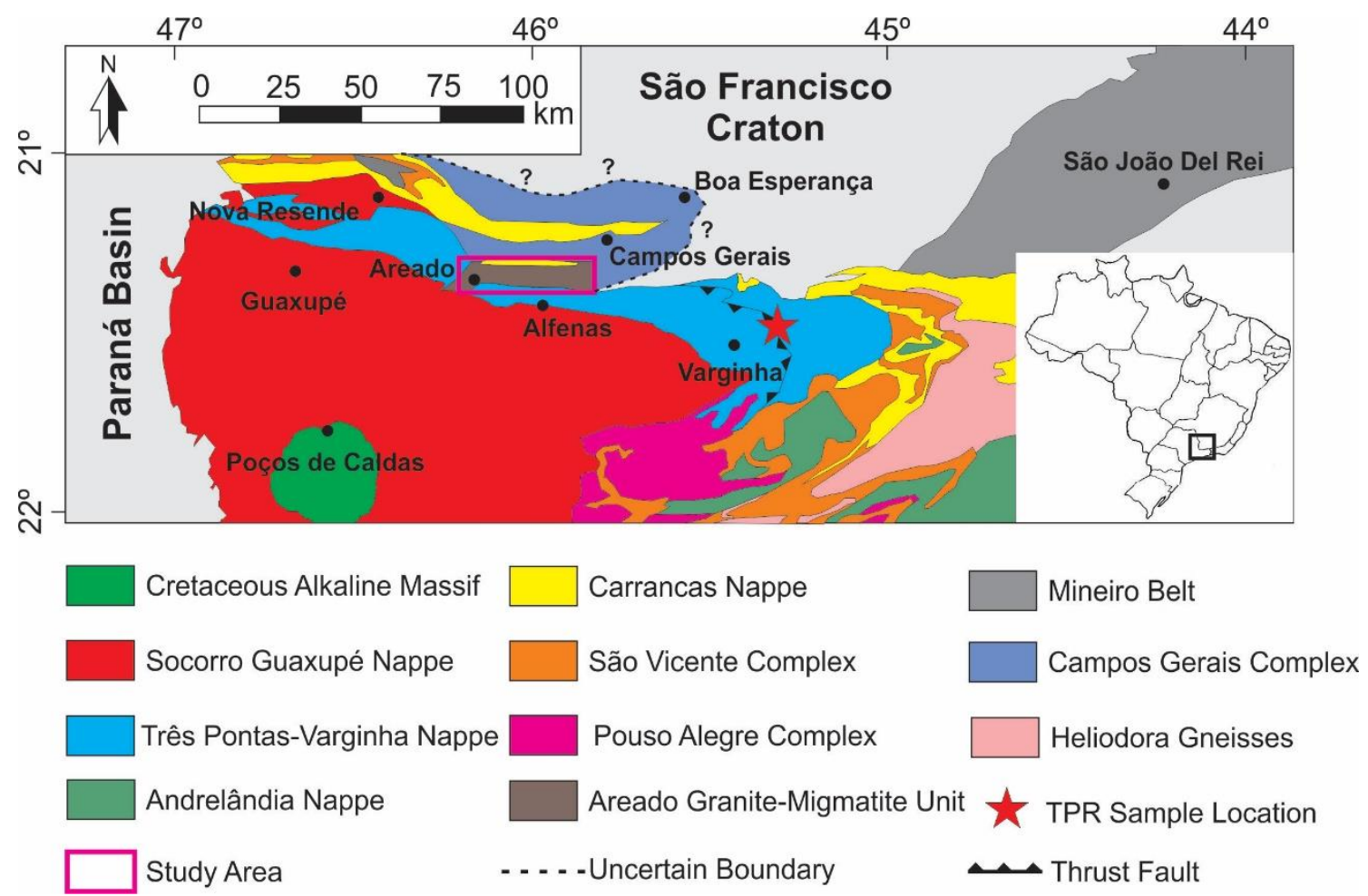

Figure 3 - Geological map of the southernmost area of the Brasilia orogen. This map shows with more detail the distribution of the units inserted in the Andrelândia Nappe System and SocorroGuaxupé Nappe, along with the Areado Granite-Migmatite Unit, the Campos Gerais Complex and units related to Passos Nappe. The yellow rectangle marks the study area from this paper and the red star points the location of the sample TPR-40. This map was generated with data from Turbay and Valeriano (2004), and Cioffi et al. (2016).

this last sequence the Andrelândia Nappe System occurs, a metasedimentary sequence associated with an active margin deposition (Campos Neto et al. 2010, 2011). The uppermost rocks of this later nappe system are associated with the Três Pontas-Varginha Nappe, which comprises high-pressure kyanite-garnetorthoclase granulite (Trouw and Castro, 1996; Campos Neto, 2000; Campos Neto and Caby, 2000; Trouw et al., 2000; Garcia and Campos Neto, 2003; Reno et al., 2009). Several studies of this unit produced results of high-pressure conditions for the metamorphic peak, between 800-900 ${ }^{\circ} \mathrm{C}$ and minimum pressures of 15 kbar (Trouw et al., 1998; Campos Neto and Caby, 1999; 2000; Garcia and Campos Neto, 2003; Campos Neto et al., 2010; Motta et al., 2010; Martinez, 2015). U-Pb monazite ages from the Andrelândia Nappe system evidence a metamorphism age of 618-595 Ma for these rocks (Campos Neto et al., 2011). 


\title{
IV.3 Analytical methods
}

\begin{abstract}
Modal QAP classification for three weakly deformed/metamorphosed garnet meta-syenogranite samples and four hornblende-garnet metatexite samples was performed by counting at least 500 points in thin sections. Proportions of megacrysts, when these are present, were estimated using outcrop photographs to establish megacrysts/matrix ratio, using a $20 \times 30$ squares grid of $43 \mathrm{~mm}$, to be integrated into modal proportion derived from thin sections.
\end{abstract}

Quartz c-axis orientations were measured using a four-axis Leitz Wetzlar universal-stage coupled to a Zeiss Ortholux microscope in thin sections cut perpendicular to the foliation and parallel to the stretching lineation. Quartz c-axis data were plotted in the Schmidt-Lambert lower hemisphere grids, using Stereo32 software.

Analyses of quartz and titanite were acquired using an iCAP-Q-ICP-MS, by Thermo Scientific with a solid-state New Wave 213 A/F laser coupled, using $100 \mu \mathrm{m}$ thick thin sections. In the investigated samples, ten quartz crystals were analyzed, in which a raster profile was made along with them, and fourteen titanite crystals were analyzed, but doing spots on each one (analytical uncertainties, $2 \sigma$, of 1.22 and 14.44, respectively). An internal calibration curve was built with Heraeus synthetic glasses as standard for quartz, and for titanite using standards from NIST, with data refinement and reduced using Glitter v. 4.4.4. Analytical conditions from LA-ICP-MS for these analyses are summarized in Table 1. All these laboratories are linked to the NAP-Geoanalítica Facilities of the Institute of Geosciences, University of São Paulo, Brazil.

Zircon and titanite grains were separated from four samples of all rocks that were collected in selected outcrops for U-Pb dating (ARE-04 and CGE25 samples from the garnet meta-syenogranite; CGE-05 from the hornblendegarnet metatexite and CGE-03Zr from the biotite stromatic diatexite; see Fig. 4 for locations). One of the analyses was carried out using a Thermo Scientific Neptune LA-MC-ICP-MS and an Excimer 193nm laser from Photon Machine, at CPGeo Facility, Institute of Geosciences, University of São Paulo, Brazil. The other five data were obtained in Sensitive high-resolution ion microprobe 
(SHRIMP Ile/MC) at the Institute of Geosciences, University of São Paulo, Brazil. Concentrations were made following a protocol designed by Loios (2004) and analytical procedures, as described by Sato et al. $(2008,2014)$. For dataset treatment, Concordia plots were constructed with the ISOPLOT 4.11 spreadsheet (Ludwig, 2003). Analyses with common lead content over 5\% and discordance over $5 \%$ were discarded. Once all the crystallization $\mathrm{U}-\mathrm{Pb}$ ages obtained were older than $1.300 \mathrm{Ma}$, the ${ }^{207 \mathrm{~Pb} / 206} \mathrm{~Pb}$ ages were used in a Probability Density Plot (PDP) to dispose of the most representative age graphically.

Table 1 - Analytical conditions for in situ analysis in quartz and titanite in LA-ICP-MS

\begin{tabular}{llll}
\hline Analyzed Material & Spot Size $(\mu \mathrm{m})$ & Laser Fluency $\left(\mathrm{J} / \mathrm{cm}^{2}\right)$ & Repetition Rate $(\mathrm{Hz})$ \\
\hline Quartz (thin section) & 80 & 3,765 & 20 \\
Quartz (block) & 80 & 14 & 20 \\
Titanite & 55 & 2 & 15 \\
\hline
\end{tabular}

Additional zircon grains were extracted from biotite diatexite (TPR-40) via traditional methods of disaggregation, magnetic and heavy liquid separation. These were mounted in 25-mm diameter epoxy discs together with NBS-610 glass and primary and secondary zircon standard material, polished to approximately half-grain thickness, carbon-coated, and then imaged by cathodoluminescence $(\mathrm{CL})$ using a TESCAN MIRA3 FESEM. The mounts were then cleaned and covered with a $40 \mu \mathrm{m}$ gold coat prior to $\mathrm{U}-\mathrm{Pb}$ isotopic analysis using the Sensitive High-Resolution Ion Microprobe (SHRIMP II). All this equipment is housed in the John de Laeter Centre of Mass Spectrometry at Curtin University.

SHRIMP II was operated at a mass resolution of 5,000 , with a primary beam current of $2 \mathrm{nA}$ and beam diameter of $20 \mu \mathrm{m}$, and a 6-scan cycle was used during analysis (de Laeter and Kennedy, 1998; Kennedy and de Laeter, 1994). NBS-610 glass was used to calibrate the position of the ${ }^{204} \mathrm{~Pb}$ peak. CUYZ (Curtin internal laboratory standard - $568.55 \mathrm{Ma}$ ) was used as the primary standard and OGC (Stern et al., 2009) as a secondary standard. Data were processed using SQUID II and Isoplot 3.75 (Ludwig, 2009, 2003). The ${ }^{207} \mathrm{~Pb} /{ }^{206} \mathrm{~Pb}$ age of secondary standard determined during the analytical session was $3461.0 \pm 8.4$ $\mathrm{Ma}$, which is within error of the published age (3465.4 $\pm 0.6 \mathrm{Ma}$; Stern et al., 2009). U-Pb data are presented in Table S1 (Supplementary Material). 


\section{IV.4 The Areado Granite-Migmatite Unit}

The northern and southern boundaries of the Areado Granite-Migmatite Unit (hereafter Areado Unit) are characterized by sheared tectonic contacts with units of very distinct nature and evolution. To the north, it overrides a unit of reddish muscovite quartzite that presents a schistosity marked by the preferred orientation of muscovite and opaque mineral-rich layers. In its southern boundary, the Areado Unit is overridden by (high-pressure) kyanite-garnetorthoclase granulite from the Três-Pontas Varginha Nappe. Very close to the contact, the granulite has a mylonitic foliation marked by stretched K-feldspar, garnet, kyanite, and quartz and all of them mark an intense mineral stretching lineation. The Areado Unit was divided into three subunits: garnet metasyenogranite, hornblende-garnet metatexite and biotite stromatic diatexite, as described below (Fig. 4A, B).

\section{IV.4.1 Garnet meta-syenogranite}

The garnet meta-syenogranite has a massive inequigranular blastoporphytic texture (Fig. 5A), with a weak foliation close to the edge of the body or within localized shear zones. Its color is grey with localized red garnet crystals. Euhedral phenocrysts of perthitic microcline, with size between 0.8 and $7 \mathrm{~cm}$, are set in a groundmass composed of K-feldspar, plagioclase, quartz, biotite, garnet, titanite, ilmenite, zircon, apatite and allanite (Table 2). The groundmass has inequigranular seriate texture, varying from medium to coarsegrained. Rare leucosome veins with idioblastic hornblende occur (Fig. 5B, C). 


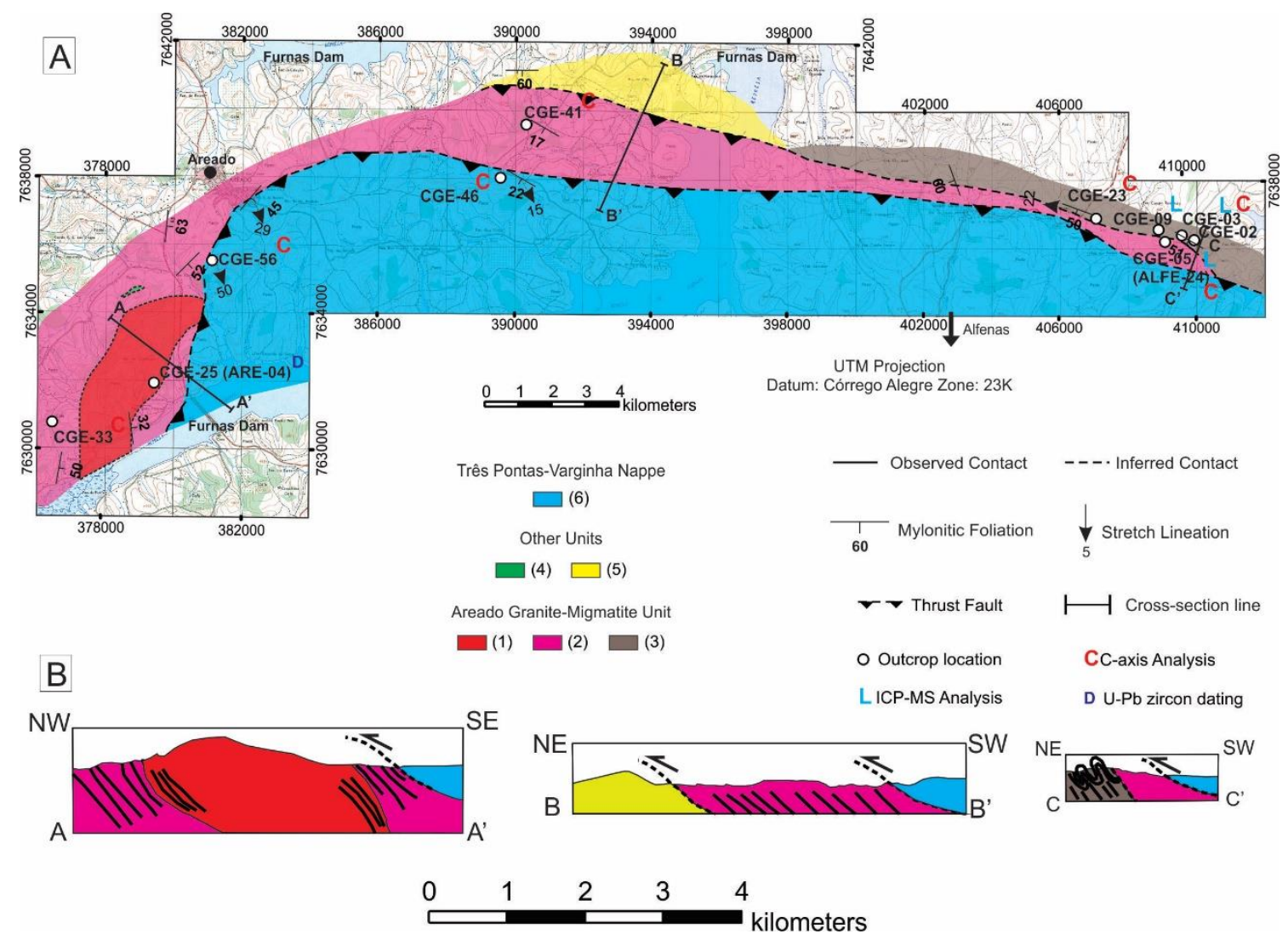

Figure 4 - (A) - Geological map of the study area, marked in Fig 2. Here is shown the essential outcrops for this paper, the analysis applied in each rock, and the most representative structural data. For the full-size map, visit the Apendix section. The units described are 1- Garnet metasyenogranite; 2- Hornblende-garnet metatexite; 3- Biotite stromatic diatexite; 4- Garnet Amphibolite; 5- Muscovite quartzite and 6- Kyanite-garnet granulite with rutile. Units are ordered by stratigraphic position. (B) - Cross-sections generated from the structural data present on the map. The vertical scale is equal to the horizontal scale. All cross-sections show that Areado Granite-Migmatite Unit structures are controlled by the thrust of the kyanite bearing granulite.

Quartz crystals have undulose extinction and rounded, lobated, and irregular contacts, suggesting that deformation was accommodated by grain boundary migration recrystallization mechanism (GBM). Plagioclase is tabular with optical compositional zoning and wedge-shaped albite twinning. Garnet exclusively occurs intergrown with $\mathrm{K}$-feldspar and sometimes biotite in finegrained reaction-rim coronas surrounding partially corroded grains of coarsegrained plagioclase, K-feldspar and biotite (Fig. 6A). Films of plagioclase surrounding garnet and $\mathrm{K}$-feldspar in these coronas are pseudomorphing a 

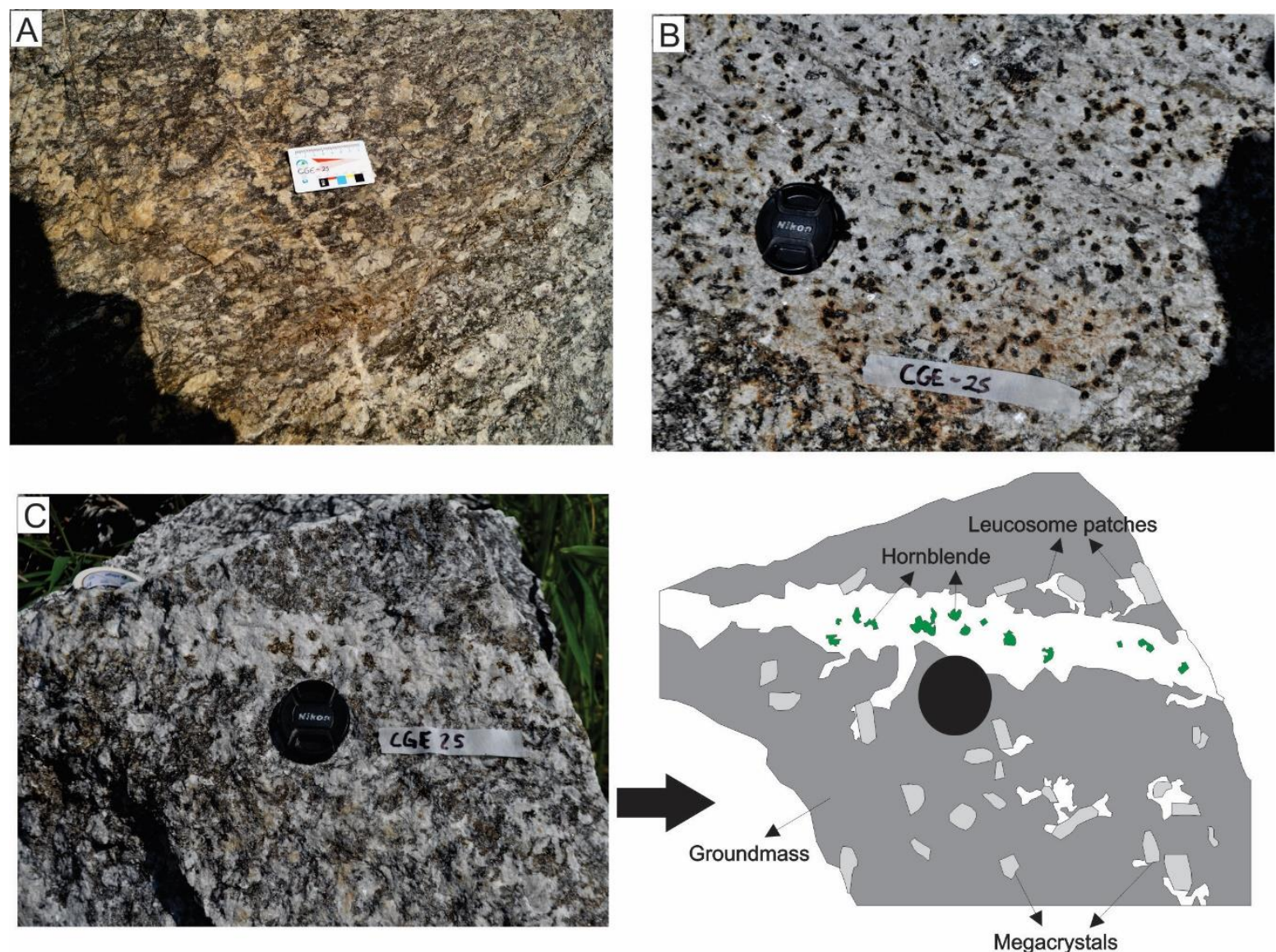

Figure 5 - Photographs from: $(A)$ - The main texture of the Garnet meta-syenogranite. It is possible to observe the phenocrysts of K-feldspar weakly oriented and a cross-cutting vein. (B) - Leucosome patch inside the Garnet meta-syenogranite with idioblastic hornblende inside. (C) - Central leucosome vein channelling smaller leucosome veins in contact with K-feldspar phenocrysts. The sketch highlights the leucosome patches forming in the contact of the phenocrysts and the groundmass of the rock, and its connection to the leucosome vein.

former melt phase (e.g., Sawyer, 1999, Fig. 5C). A second generation of biotite occurs as xenomorphic grains, mostly with partial replacement by chlorite. IImenite crystals are xenomorphic and present a corona of metamorphic titanite (Fig. 6B), when in contact with plagioclase. Idiomorphic to subdiomorphic grains of apatite present coronas of allanite. 

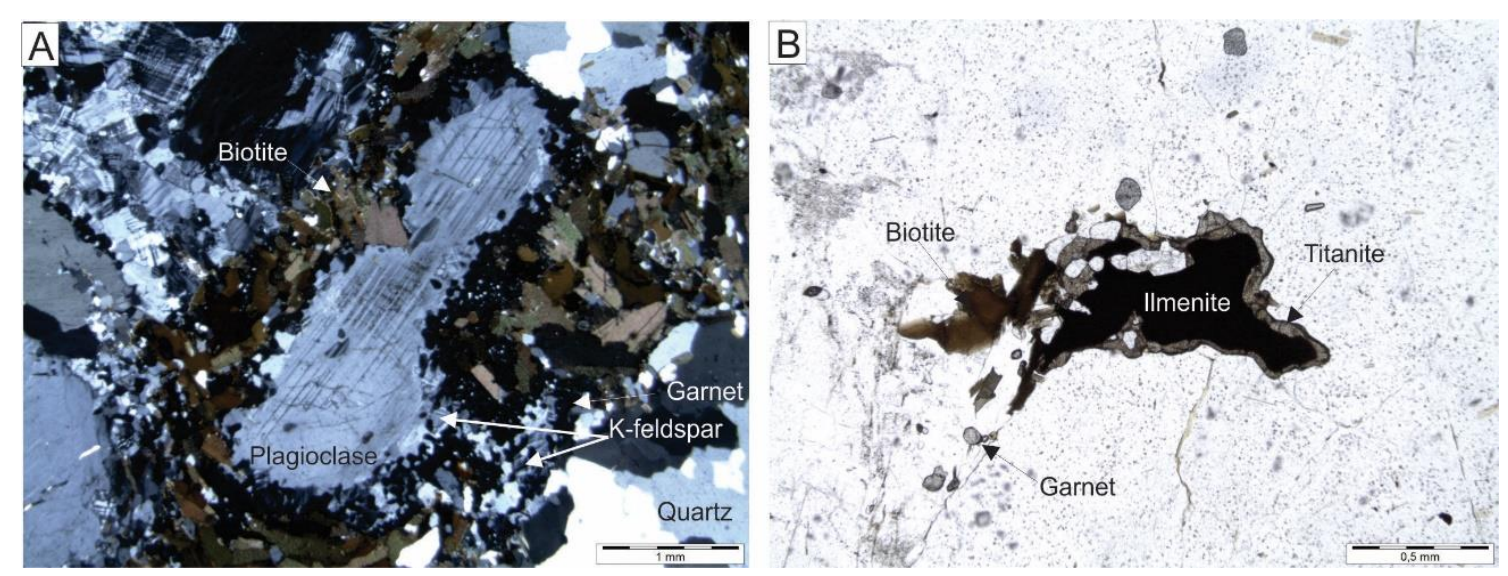

Figure 6 - Photomicrographs: (A) - Igneous plagioclase crystal mantled by metamorphic garnet and metamorphic K-feldspar when in contact with biotite in the Garnet meta-syenogranite unit. This texture comprehends a reaction between igneous plagioclase and biotite, forming metamorphic garnet and k-feldspar. (crossed polarized light). (B) - Anhedral opaque crystal mantled by titanite rim on the Garnet meta-syenogranite, which represents the substitution of the opaque by titanite during metamorphism (uncrossed polarized light).

\section{IV.4.2 Hornblende-garnet metatexite}

The hornblende-garnet metatexite is an inequigranular rock with centimetric $\mathrm{K}$-feldspar porphyroclasts, while minerals at the matrix are millimetric (Fig. 7A). The rock has a mylonitic foliation marked by $\mathrm{K}$-feldspar porphyroclasts, recrystallized quartz lenses, and, by biotite, which has, locally, totally replaced by garnet. The leucosome appears as patches and in veins, which crosscut the foliation planes. Shear zones cut the foliation and some host leucosome, as well (Fig. 7A).

The leucosome is composed of K-feldspar, quartz, plagioclase $\left(A n_{28}\right)$, and hornblende. Quartz grains present lobed boundaries and undulose extinction, which indicates it recrystallized by GBM. The K-feldspar porphyroclasts have inclusions of euhedral plagioclase, indicating its igneous origin, whereas the smaller crystals were originated by recrystallization and are sitting at porphyroclasts rims or matrix. Hornblende occurs in the leucosome, as idioblastic crystals with inclusions of quartz, plagioclase, K-feldspar, garnet, allanite, titanite and zircon.

The residuum is composed of porphyroclasts of $\mathrm{K}$-feldspar, and a matrix of quartz, xenoblastic crystals of plagioclase and K-feldspar, garnet, titanite, allanite, zircon, and apatite. Garnet crystals are idioblastic, with titanite, allanite 
and zircon inclusions. The biotite is subdioblastic and occurs at the edge of garnet and hornblende crystals. Allanite exhibits medium to coarse-grained xenoblastic grains, with inclusions of subdioblastic titanite and apatite. Titanite occurs either as subdioblastic crystals, with straight borders against quartz and feldspar, or as xenoblastic agglomerates with garnet and allanite inclusions.

Despite the intense deformation, melt crystallization textures (e.g., Sawyer, 1999, 2001; Marchildon and Brown, 2002; Holness and Sawyer, 2008), such as small quartz or feldspar films surrounding garnet grains (Fig. 8A) and a second generation of K-feldspar filling porphyroclast fractures (Fig. 8B), both mimicking a trapped melt phase, are present. 
Table 2 - Modal analysis from most representative samples. The mineral proportion already considers a matrix/phenocrystals proportion of $58 / 42$ for the meta-syenogranite unit, and a matrix/porphyroclasts proportion of 74/26 for the hornblende-garnet metatexite unit. Both proportions were obtained by photography modal counting.

\begin{tabular}{|c|c|c|c|c|c|c|c|c|c|c|c|c|c|c|c|c|}
\hline nit & ample type & Samples & Qtz & $\mathrm{PI}$ & Kfs & $\mathrm{Bt}$ & Grt & Tit & Op & $\mathrm{Hbl}$ & Aln & Ap & $\mathrm{Zr}$ & Ms & Ep & otal \\
\hline \multirow{4}{*}{$\begin{array}{c}\text { Meta- } \\
\text { syenogranite }\end{array}$} & \multirow{4}{*}{ Whole Rock } & ARE-4C & $19 \%$ & $21 \%$ & $50 \%$ & $6 \%$ & $2 \%$ & $1 \%$ & $1 \%$ & Trace & Trace & Trace & Trace & Trace & Trace & $100 \%$ \\
\hline & & A & $24 \%$ & $16 \%$ & $49 \%$ & $7 \%$ & $2 \%$ & race & $1 \%$ & Trace & Trace & $1 \%$ & Trace & Trace & Trace & 100 \\
\hline & & CGE-25C & $12 \%$ & $24 \%$ & $54 \%$ & $7 \%$ & $1 \%$ & $1 \%$ & Trace & Trace & Trace & Trace & Trace & Trace & Trace & $100 \%$ \\
\hline & & Mean & $18 \%$ & $20 \%$ & $51 \%$ & $7 \%$ & $2 \%$ & $1 \%$ & $1 \%$ & Trace & Trace & Trace & Trace & Trace & Trace & $100 \%$ \\
\hline \multirow{5}{*}{$\begin{array}{c}\text { Hornblende- } \\
\text { garnet } \\
\text { metatexite }\end{array}$} & \multirow{5}{*}{ Whole Rock } & $\mathrm{CGE}$ & $21 \%$ & $11 \%$ & $53 \%$ & Trace & $8 \%$ & $2 \%$ & Trace & $4 \%$ & $1 \%$ & Trace & Trace & Trace & Trace & $100 \%$ \\
\hline & & CGE-05B & $19 \%$ & $13 \%$ & $54 \%$ & $1 \%$ & $7 \%$ & $1 \%$ & Trace & $4 \%$ & $1 \%$ & Trace & Trace & Trace & Trace & $100 \%$ \\
\hline & & CGE-06B & $29 \%$ & $7 \%$ & $47 \%$ & $1 \%$ & $6 \%$ & $1 \%$ & Trace & $8 \%$ & $1 \%$ & Trace & Trace & Trace & Trace & $100 \%$ \\
\hline & & CGE & $23 \%$ & $7 \%$ & $55 \%$ & $1 \%$ & $7 \%$ & $1 \%$ & Trace & $5 \%$ & $1 \%$ & Trace & Trace & Trace & Trace & $100 \%$ \\
\hline & & Mean & $23 \%$ & $10 \%$ & $52 \%$ & $1 \%$ & $7 \%$ & $1 \%$ & Trace & $5 \%$ & $1 \%$ & Trace & Trace & Trace & Trace & $100 \%$ \\
\hline \multirow{10}{*}{$\begin{array}{c}\text { Biotite } \\
\text { stromatic } \\
\text { diatexite }\end{array}$} & \multirow{4}{*}{ Whole } & CGE-03C & $27 \%$ & $38 \%$ & $12 \%$ & $18 \%$ & Trace & Trace & Trace & Trace & Trace & Trace & Trace & $2 \%$ & $1 \%$ & $100 \%$ \\
\hline & & CGE-21 & $36 \%$ & $37 \%$ & $15 \%$ & $7 \%$ & Trace & Trace & Trace & Trace & Trace & Trace & Trace & $4 \%$ & Trace & 100 \\
\hline & & CGE-23B & $36 \%$ & $33 \%$ & $10 \%$ & $16 \%$ & Trace & Trace & Trace & Trace & Trace & Trace & Trace & $3 \%$ & $1 \%$ & $100 \%$ \\
\hline & & Mean & $33 \%$ & $36 \%$ & $12 \%$ & $14 \%$ & Trace & Trace & Trace & Trace & Trace & Trace & Trace & $3 \%$ & $1 \%$ & $100 \%$ \\
\hline & \multirow{3}{*}{ Leucosome } & CEG-03EL1 & $35 \%$ & $26 \%$ & $29 \%$ & $4 \%$ & Trace & Trace & Trace & Trace & Trace & Trace & Trace & $6 \%$ & Trace & $100 \%$ \\
\hline & & CGE-03EL6 & $34 \%$ & $34 \%$ & $27 \%$ & $3 \%$ & Trace & Trace & Trace & Trace & Trace & Trace & Trace & $1 \%$ & $1 \%$ & $100 \%$ \\
\hline & & Mean & $35 \%$ & $30 \%$ & $28 \%$ & $4 \%$ & Trace & Trace & Trace & Trace & Trace & Trace & Trace & $3 \%$ & Trace & $100 \%$ \\
\hline & \multirow{3}{*}{ Residuum } & CGE-03ER1 & $20 \%$ & $35 \%$ & $7 \%$ & $30 \%$ & Trace & Trace & Trace & Trace & Trace & Trace & Trace & $2 \%$ & $6 \%$ & $100 \%$ \\
\hline & & CGE-03ER4 & $28 \%$ & $36 \%$ & $9 \%$ & $21 \%$ & Trace & Trace & Trace & Trace & Trace & Trace & Trace & $4 \%$ & $2 \%$ & 100 \\
\hline & & Mean & $24 \%$ & $36 \%$ & $8 \%$ & $25 \%$ & Trace & Trace & Trace & Trace & Trace & Trace & Trace & $3 \%$ & $4 \%$ & $100 \%$ \\
\hline
\end{tabular}



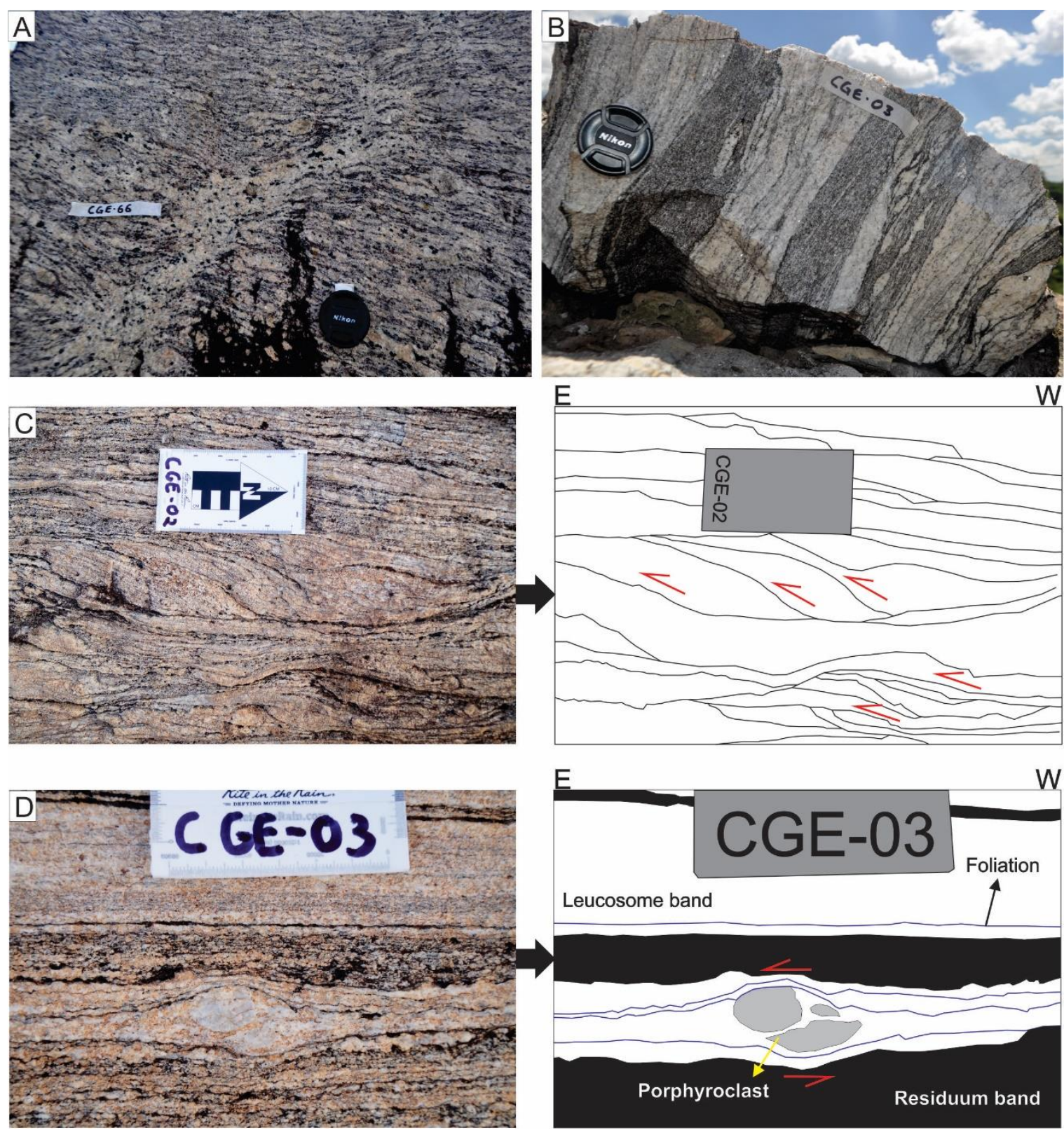

Figure 7 - Photographs of $(A)$ - Main texture from the hornblende-garnet metatexite. It is possible to see a shear zone, with deformed minerals at its edges, channelling the leucosome in a patch. (B) - Cross-section view from the leucosome and residuum bands from the biotite stromatic diatexite, emphasizing the stromatic character of this unit. (C) - E-W horizontal view from the biotite stromatic diatexite unit. This picture shows the behaviour of the mylonitic foliation of the rock, forming several duplex structures, as highlighted by the sketch. (D) - E-W horizontal view of the main structure of the biotite stromatic diatexite unit. The image focuses attention on the relation between the leucosome and residuum band, along with a rotated deformed porhyroclast. 

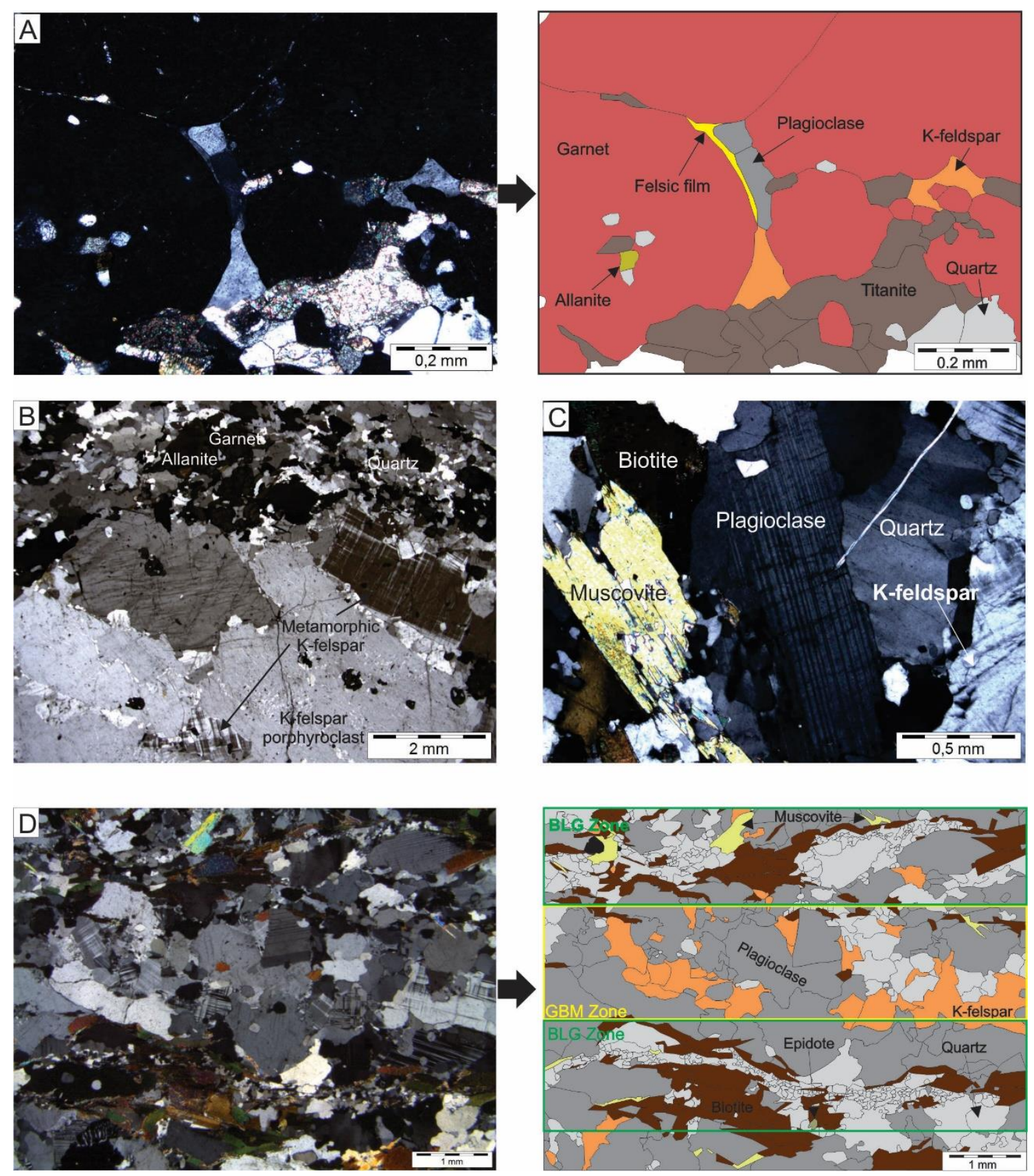

Figure 8 - Photomicrographs of: (A) - Felsic film mimicking melt in garnet contacts at the hornblende-garnet metatexite residuum. This texture is associated with a melt crystallization (crossed polarized light). (B) - K-feldspar porphyroclast from the hornblende-garnet metatexite, surrounded by quartz, garnet and allanite. The crystallization of a metamorphic k-feldspar generation inside the porphyroclast is a melt crystallization texture and corroborates partial melting in the rock (crossed polarized light). (C) - Biotite stromatic diatexite melanosome highlighting a preserved igneous plagioclase crystal, together with a late-stage muscovite crosscutting biotite (crossed polarized light).(D) - The overall texture from the biotite stromatic diatexite that presents the leucossome and residuum of the rock. The sketch focus on the different quartz textures, showing lobated crystals in the leucosome, in which prevailed the grain boundary migration (GBM) process, while the melanosome has microcrystals of quartz close to biotite, thus where bulging (BLG) process dominates in this unit (crossed polarized light). All samples were made perpendicular to the foliation of the rock and parallel to the lineation. 


\section{IV.4.3 Biotite stromatic diatexite}

The biotite stromatic diatexite is the most voluminous subunit, sitting at the base of the Areado Unit (Fig. 4). The term diatexite is used here because the degree of partial melting was high enough to destroy all original igneous texture, and the syn-anatexis intense deformation was responsible to imprint a stromatic structure in the rock (Fig. 7B), marked by a white leucosome and a black or grey residuum, rich in biotite. The mylonitic foliation is best represented by intensely deformed biotite. Two different fold types are observed, intrafolial, and open harmonic types (Fig. 14A and B). In addition to the mylonitic foliation, boudins of biotite-rich layers, S-C foliation (Fig. 7C) and rotated porphyroclasts (Fig 7D) are recognized.

The residuum reaches between $70-60 \%$ in volume (Table 2), being composed of biotite, plagioclase, quartz, epidote, titanite, muscovite, allanite, and zircon. Biotite is subdioblastic, has microstructural features, such as mica fish and defines pairs of S-C foliations. Allanite occurs with a total or partial corona of epidote, indicating it was replaced by the last, in a similar way as described by Finger et al. (1998). Quartz occurs as grains with straight contact, usually forming bands. Most plagioclase crystals are rounded without twinning and present concentric extinction. Retrograde muscovite overgrowth biotite grains and form symplectites with quartz and K-feldspar (Fig. 8E), evidencing a replacement in an open system.

The leucosome is composed of plagioclase $\left(\mathrm{An}_{27}\right)$, quartz, and K-feldspar. Although leucosome is easily recognized in the field, in thin sections, minerals are deformed, and pristine igneous textures are rare. Although with feldspar grains with irregular boundaries being more common, there are euhedral plagioclase crystals with igneous texture preserved (Fig. 8C). Rarely, some perthitic microcline porphyroclasts occur. Quartz in these layers present lobated boundaries. 


\section{IV.5 U-Pb zircon and titanite dating}

In order to constrain the age of igneous crystallization and metamorphism, four zircon and two titanite mounts from studied rocks were prepared for U-Pb dating.

The selected zircon crystals generally present homogeneous typology varieties, with 100 and $400 \mu \mathrm{m}$ size. The most common morphological types include elongate crystals, exhibiting rounded to oval-shaped terminations. Between the most common zircon internal features, it is possible to observe: (1) bright cores exhibiting tenuous oscillatory zones; (2) thin homogeneous rims, darker than the cores and possibly generated by recrystallization; (3) metamitic zones are developed preferably along the rim-core boundaries; (4) the absence of inherited cores; and (5) an intense fracturing in crystals of the biotite stromatic diatexite unit (See Apendix).

For U-Pb data acquirement in LA-MC-ICP-MS of the garnet metasyenogranite, thirty-eight spots were concentrated at the bright cores, and among those, fourteen analyses were used to calculate the Concordia date at $2069.8 \pm 5$ Ma (Fig. 9A). SHRIMP lle analyses used between twelve and fifteen spots to calculate the isocron intercepts, resulting in $2079 \pm 21 \mathrm{Ma}$ date for the garnet metasyeno-granite (Fig. 9B) and $2083 \pm 12 \mathrm{Ma}$ for the hornblende-garnet metatexite unit (Fig. 9C). Although zircon crystals from the biotite stromatic diatexite present a significant amount of fractures, six-spot analysis from metamorphic rims resulted in a Concordia date of $604.2 \pm 6.3 \mathrm{Ma}$ (Fig. 9D). This date is younger than obtained by the lower intercept of the garnet metasyenogranite $(657 \pm 40 \mathrm{Ma}$, Fig. 9B) and the hornblende-garnet metatexite (671 $\pm 58 \mathrm{Ma}$, Fig. 9C). 

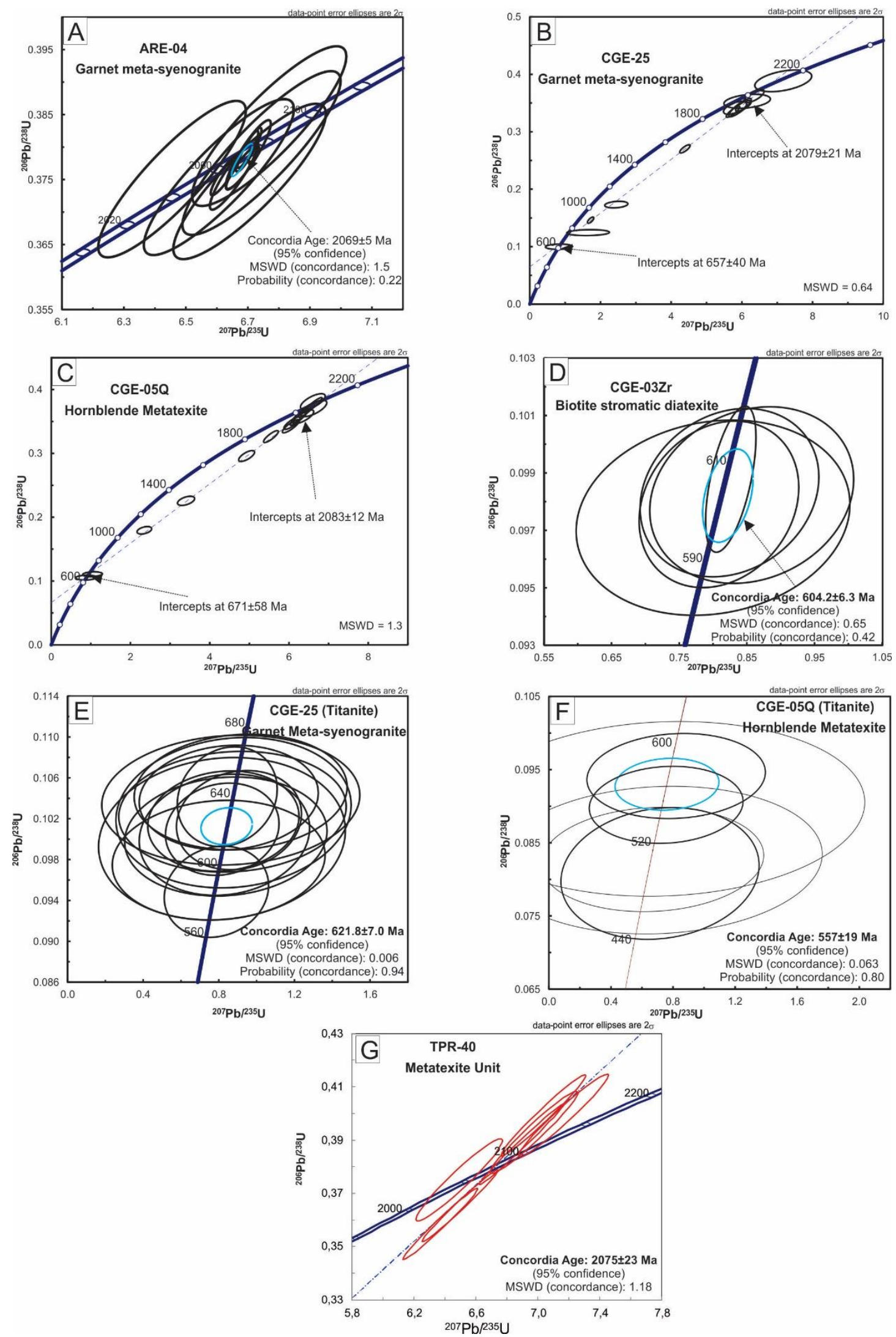

Figure 9 - Isocron graphs showing U-Pb analysis results. (A) - Sample of the garnet meta-syenogranite zircons on LA-ICP-ME-MS with the calculated Concordia Age. (B) - Isocron from zircon analysis of the meta-syenogranite, showing upper and lower intercepts. (C) - Isocron from zircon analysis of the hornblende metatexite, with upper and lower intercepts. (D) - Zircon analysis results from the Biotite stromatic diatexite, along with the calculated Concordia age. (E) - Titanite isocron from the metasyenogranite with the calculated Concordia age. (F) - Calculated Concordia Age for titanite data from the metatexite unit.(G) Concordia diagram for zircon analyzed via SHRIMP II. From (B) to (F), all analysis have been made on SHRIMP from IGc-USP. 
In addition to the metamorphic ages obtained with zircon, titanite crystals from the garnet metasyeno-granite and hornblende-garnet metatexite have been dated. These crystals are granular, mostly with angular shapes, with 100 to 200 $\mu \mathrm{m}$. Cathodo luminescence $(\mathrm{CL})$ images show no signs of zoning in the crystals, only a homogeneous dark area. U-Pb analysis in SHRIMP from the garnet metasyenogranite gave a calculated Concordia date of $621.8 \pm 7.0 \mathrm{Ma}$ (Fig. 9E). Data from the hornblende-garnet metatexite have a high content of common $\mathrm{Pb}$ and should be carefully treated. Still, Concordia date calculated from those crystals is $557 \pm 19$ Ma with high concordance probability (0.8, see Fig. 9F).

\section{IV.6 Quartz and titanite in situ analysis and thermobarometry}

The quartz in situ analyses were made on thin sections of the sample CGE-05 and a polished rock block of the sample CGE-03D (Fig. 4). Titanite analyses were made on samples ALFE-24E and CGE-09A (Fig. 4). All LA-ICPMS analyses were performed using the raster mode.

Fourteen large quartz crystals from samples CGE-05 and CGE-03D were analyzed, which yielded $\mathrm{TiO} 2$ concentration below $8 \mathrm{ppm}$ (Tables $\mathrm{A} 1$ and A2 - see Apendix). The results vary between 2.8 and 7.8 ppm (CGE-05 thin sections), and from 1.2 to $6.3 \mathrm{ppm}$ (CGE-03D polished block). The TiO2 content was calculated based on an intern calibration curve made with Heraeus standard glasses, and the collected data have very good quality (see Supplementary data). Taking an average result and using the calibration by Thomas et al. (2010), temperatures between $374-650{ }^{\circ} \mathrm{C}$ are calculated for the hornblende-garnet metatexite, and $355-623{ }^{\circ} \mathrm{C}$ for the biotite stromatic diatexite, between 1 and 15 kbar (Fig. 10A). These calculations took into account an aTiO2 of 0.5 , which is considered a lower limit for crustal rocks (Hayden and Watson, 2007). Ashley et al. (2014) propose an aTiO2 value of 0.2 for deformed rocks since deformation can relocate Ti inside quartz structure. If it is applied to these analyses, the results change to $450-732^{\circ} \mathrm{C}$ for the hornblende-garnet metatexite and $428-700{ }^{\circ} \mathrm{C}$ for the biotite stromatic diatexite (Fig. 10B). 

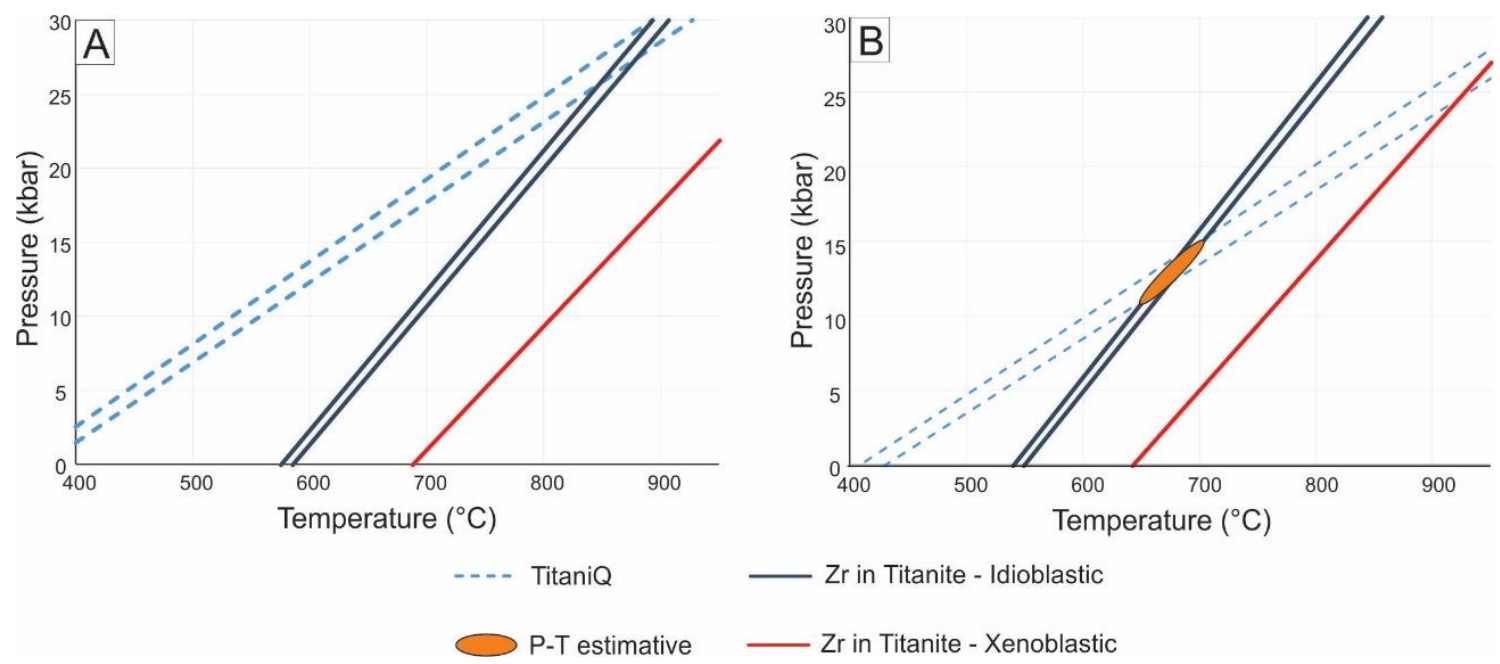

Figure 10 - P-T diagram showing (A) - Calculated temperature with TitaniQ and Zr in titanite using titanium activity equal to 0.5 as suggested by Hayden \& Ward (2007). (B) - Calculated temperature with TitaniQ and $\mathrm{Zr}$ in titanite using titanium activity equal to 0.2 , as suggested by Ashley et al. (2014). The $\mathrm{Zr}$ in titanite was separated by textural group, indicated in Figure 13.

Thirteen titanite crystals from samples CGE-09 and ALFE-24 were analyzed, including twelve idioblastic and one xenoblastic grain (Fig. 11A, Tables A3 and A4). A stoichiometric composition from average titanite crystals was used for trace element calculation (Deer et al., 1992) for Glitter calibration. The titanite REE chondrite normalized patterns are different for each type of crystal (Fig. 11B). The idioblastic grains present a higher concentration of LREE, from La to Sm, and a discrete negative Eu anomaly. HREE have a slightly concave curvature between Gd and Dy, and a decrease from this element to Lu (Fig. 10B).

On the other hand, the xenoblastic titanite grain also has a positive slope for LREE, a pronounced negative Eu anomaly, and almost flat distribution of HREE, with a small decrease between Gd and Lu (Fig. 11B). These patterns indicate that xenoblastic titanite might have formed before or along with other HREE rich minerals, such as zircon or garnet (Bea, 1996), whereas idioblastic titanite must have formed after these phases, even after the xenoblastic grains. The negative Eu anomalies suggest that both types of titanite crystals formed at subsolidus conditions after all feldspars have crystallized from the melt and captured its Eu.

The Zr-in-titanite thermometer calibrated by Hayden et al. (2008) was applied considering aTiO2 as 0.5 and aSiO2 as 1.0 , due to quartz presence in all 
samples. Zirconium content of idioblastic titanite in CGE-09 has an average of 55 ppm, which yields temperatures of $559-702^{\circ} \mathrm{C}$ for pressures between 1 and 15 kbar, respectively. Crystals from sample ALFE-24E have an average of $70 \mathrm{ppm}$ of $\mathrm{Zr}$, which yields temperatures of $569-713^{\circ} \mathrm{C}$, for the same pressure range. The xenoblastic grains show a zirconium content of $640 \mathrm{ppm}$ that corresponds to a temperature interval of $665-827^{\circ} \mathrm{C}$ (Fig. 10A). Using aTiO2 0.2 , as suggested by Ashley et al. (2014), the results change to $550-692{ }^{\circ} \mathrm{C}$ for the CGE-09 sample, $560-703{ }^{\circ} \mathrm{C}$ for idioblastic crystals, and $654-814{ }^{\circ} \mathrm{C}$ for xenoblastic crystals in ALFE-24E (Fig. 10B). The uncertainty, based on the crystals analyses, is $\pm 30^{\circ} \mathrm{C}$ for the TitaniQ and up to $20 \stackrel{\circ}{ } \mathrm{C}$ for the $\mathrm{Zr}$-in-titanite thermometer.
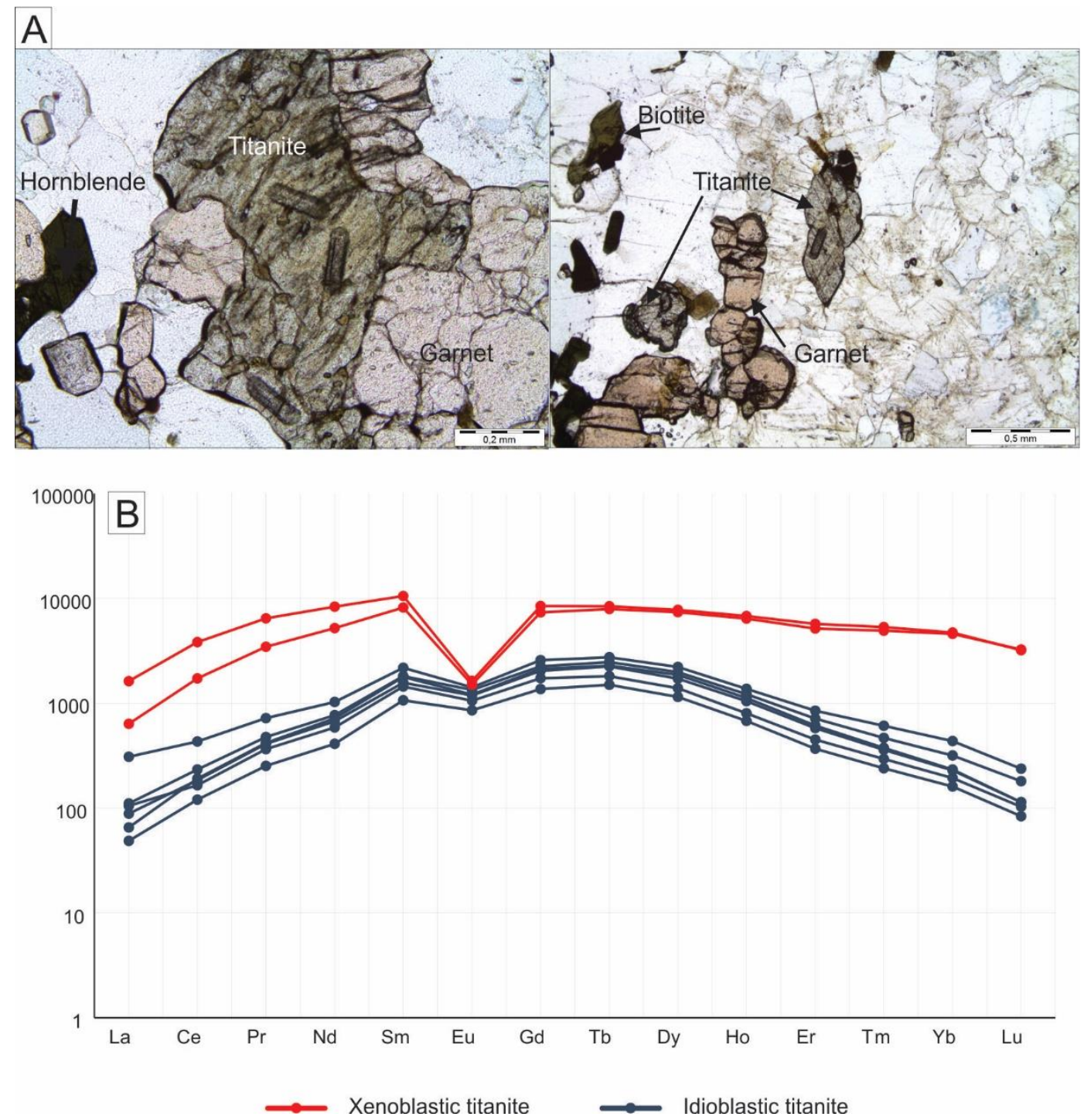

Figure 11 - (A) - Photomicrographs (uncrossed polarized light) illustrating different titanite textures on the metatexite unit residuum. The first one, correspond to a xenoblastic titanite, usually with allanite inclusions. The second are idioblastic titanites, that rarely presents any inclusions. (B) - RRE pattern from titanites normalised by the chondrite and separated by textural groups. This graph suggests that the formation of xenoblastic titatine absorbed most elements present in allanite during its formation. Idioblastic crystals' generation occurred afterwards when the system was already depleted in LREE. 


\section{IV.7 Main structures and quartz c-axis based thermometry}

A mylonitic foliation is the main structure of the study rocks. The mylonite character is represented by K-feldspar porphyroclasts and shear zones filled with leucosome in the hornblende-garnet metatexite (Fig. 7A), while S-C foliations and feldspar porphyroclasts are evident in the biotite stromatic diatexite (Fig. 7B, C). In both migmatitic units, drag folds occur as intrafolial tight folds and open folds. In the eastern and middle part of the map (Fig. 4A), the foliation has an average of N020/45SE and most structures indicate movement to NW (Fig. 12A, B). In this region, cross-sections (Fig. 4B) show that the Três Pontas-Varginha Nappe thrusts the Areado Unit with a similar shear sense, which is based on their asymmetric structures (Fig. 7C, 7D). Deformation created two different types of folds in the biotite stromatic diatexite, a tight intrafolial fold and a rounded hinge fold with an oblique axial plane (Fig. 13A). Field relationships indicate a three deformational stage process; the first one deformed a pre-existent metamorphic surface, developing a foliation $S_{n}$. The second stage formed the tight folds and the main mylonitic foliation $\left(S_{n+1}\right)$, and the third stage generated only the harmonic folds (Fig. 13B). 

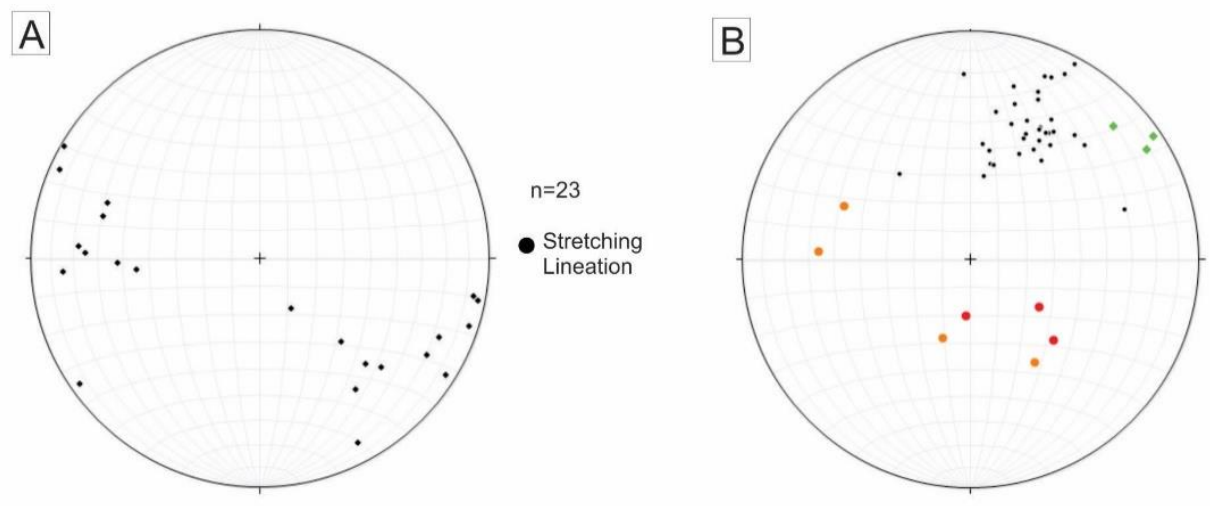

$n=45$

- Mylonitic Foliation poles (35)

Axial plane poles of 2 nd stage folds (3)

Fold axis of 2nd stage folds (3)

Fold axis of $1 \mathrm{st}$ stage folds (4)

C

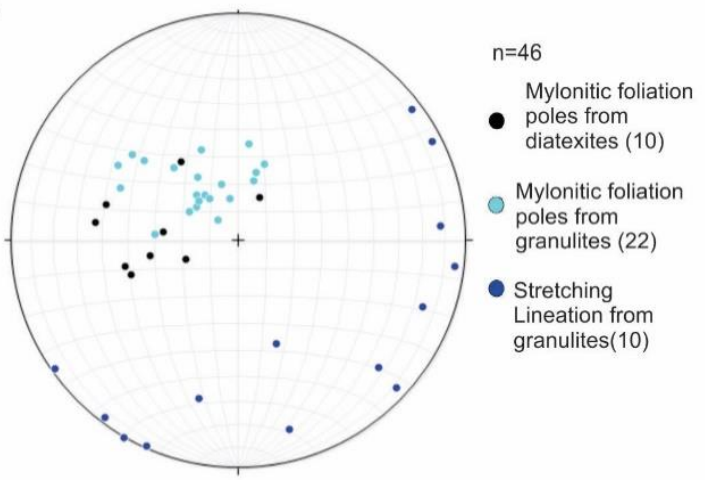

Figure 12 - Stereograms generated from the structural data obtained in the field. (A) - Stretching lineation from the biotite diatexite, mostly acquired at the eastern part of the map. (B) - Mylonitic foliation, axial plane and fold axis from the biotite diatexite. (C) - Data obtained at Areado are, and consists of mylonitic foliation from the hornblende diatexite along with foliation and stretching lineation from the kyanite granulite.

In the western part of the area, the average orientation of the foliation changes to N170/32NE, and the foliation poles match with the foliation measured in the kyanite-garnet-orthoclase granulite unit (Fig. 12C). Stretching lineation in the granulites exhibits a low-angle spread behavior (Fig. 12C). 

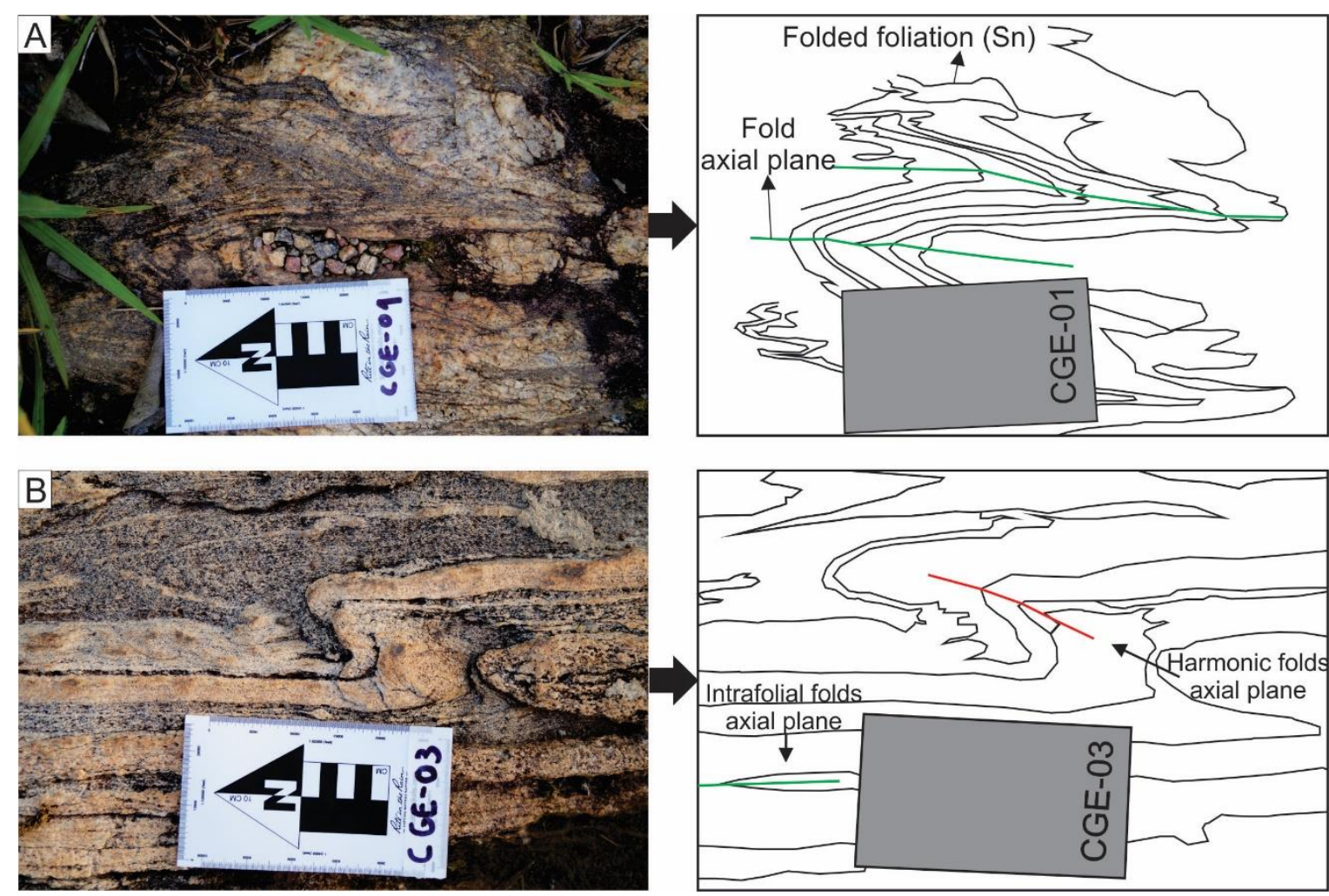

Figure 13 - Photographs of folds found in the biotite stromatic diatexite. (A) - Intrafolial fold with an axial plane parallel to the mylonitic foliation. (B) - Photograph of the same unit illustrating the second generation of folds, with an oblique axial plane concerning the mylonitic foliation. Both sketches highlight the characteristics of the folds.

In order to evaluate if it is possible to identify each deformationtemperature pulse or just the last one, the quartz c-axis thermometer was applied to a set of samples (Kruhl, 1996; Morgan and Law, 2004; Law, 2014; Faleiros et al., 2016). Quartz c-axis orientations were measured in eight thin sections (Fig. 4). All thin sections are cut parallel to stretching lineation and perpendicular to mylonitic foliation. Quartz c-axes were measured with a universal stage, and the opening angle was estimated based on the maximum concentrations.

The hornblende-garnet metatexite has quartz crystals with lobed contacts, typical of recrystallization due to GBM. The quartz c-axis pattern in stereogram forms a girdle correspondent to point c-maxima at a low angle to the stretching lineation (Fig. 14A). Most samples from the biotite stromatic diatexite present quartz recrystallization by BLG and these data present a girdle with point $\mathrm{C}$ maxima in $Y$ and an intermediate position between $X$ and $Z$ directions (Fig. 14B). However, sample CGE-23A presents lobated quartz well preserved, surrounded by small, recrystallized quartz crystals. In this case, the two different crystal types were measured separately. The small crystals data formed a girdle with a similar pattern described above, with a small rotation of the data in relation 

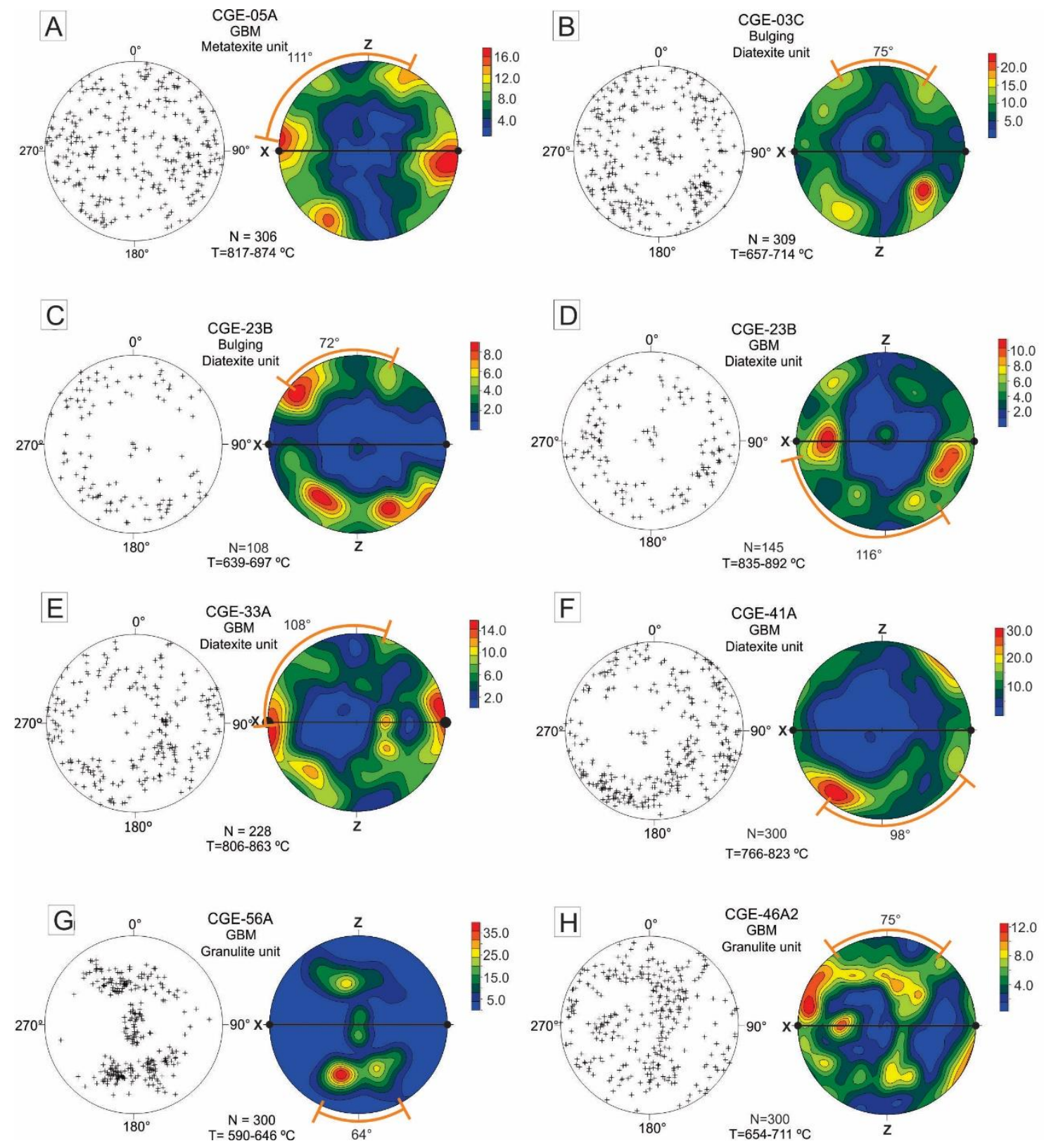

Figure 14 - Quartz c-axis fabrics measurements on lower hemisphere equal-area projections. Foliation is oriented on the X-axis, and stretching lineation is parallel to the cut. (A) graphic represents a point c-maxima at a low angle to the stretching lineation, with a rotation concerning $X$-axis, just like graphs (D), (E) and (F). Figures $7(B)$ and $(C)$ show a girdle with point C-maxima in $Y$ and an intermediate position between $X$ and $Z$ pattern, but with a small rotation in $(\mathrm{C})$. Figures $7(\mathrm{G})$ and $(\mathrm{H})$ presents an asymmetric type I crossed girdle. The temperature estimation is based on $11-15 \mathrm{kbar}$ pressure, obtained from the other thermometers (Section 7). All images shows the sample measured (visit Fig 3 for their geographic position), which recrystallisation process (grain boundary migration (GBM) or bulging) prevails in the thin section and the unit it belongs. 
to the X-axis (Fig. 14C). The lobated quartz data generated point cmaxima at low angles to the stretching lineation, however, with some imprint of low angle measurements (Fig. 14D). Other biotite stromatic diatexite samples have quartz grains recrystallized by GBM, and present quartz c-axis data of cmaxima at a low angle to the stretching lineation, with a $\mathrm{c}$-axis rotation about $\mathrm{X}$ axis (Fig. 14E and 13F). In the samples from the kyanite-garnet-orthoclase granulite, from Três Pontas-Varginha Nappe, quartz grains present GBM recrystallization and, locally, ribbons. Both samples formed asymmetric type I crossed girdles (Law, 2014; Faleiros et al., 2016; Fig. 14G, H).

The resultant deformation temperatures obtained using the calibration made by Faleiros et al. (2016) present two different clusters (Table 3 and Fig. 15). The pressure range used was that calculated with thermobarometry under atio2 equal to $0.2,11-15 \mathrm{kbar}$. The first group corresponds to high deformation temperature, varying from 766 to $934^{\circ} \mathrm{C}$, between upper amphibolite and granulite facies. This cluster matches the hornblende-garnet metatexite, the biotite stromatic diatexite from the Areado region, and quartz crystals with GBM texture of the biotite stromatic diatexite of the Alfenas region. The second cluster corresponds to an amphibolite facies deformation temperature, varying from 591 to $714{ }^{\circ} \mathrm{C}$. Quartz $\mathrm{c}$-axis measurements from the kyanite-garnet-orthoclase granulite give a range of $518-711^{\circ} \mathrm{C}$ at the same pressure, which is a lower deformation temperature than the Areado Unit metamorphic peak. 


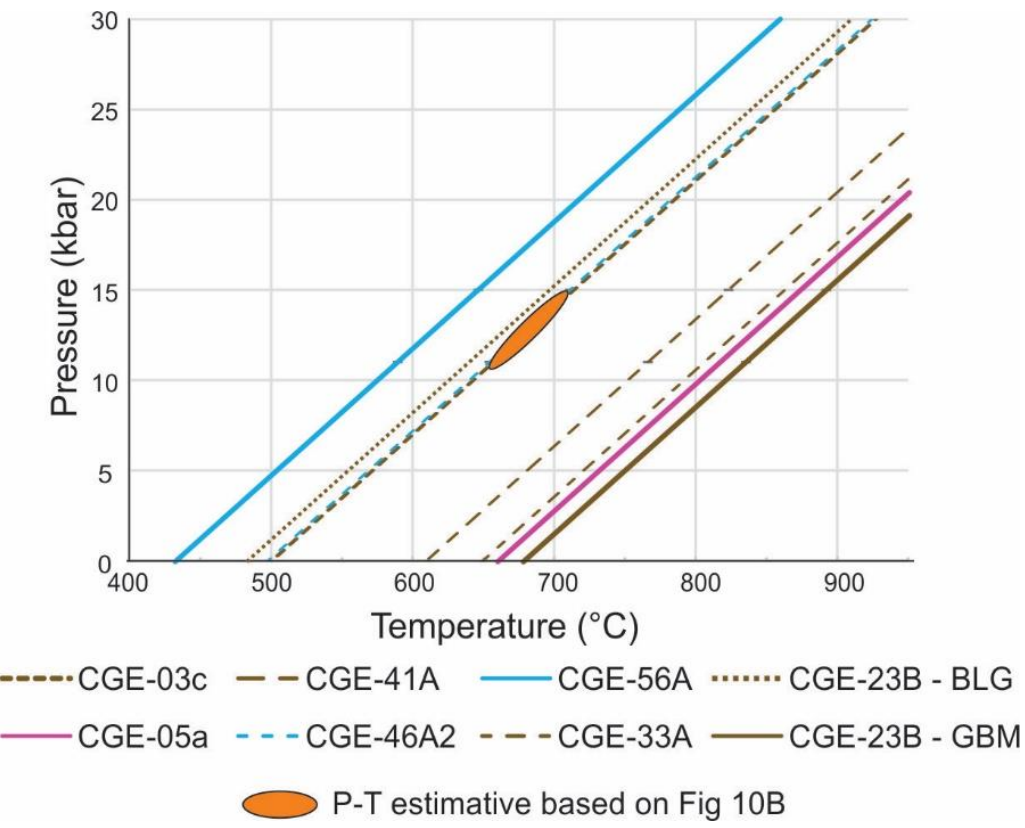

Figure 15 - C-axis thermobaromether results plotted on a P-T diagram. The colours of the lines represent the mapping units from Fig 3.P-T estimative based on TitaniQ and $\mathrm{Zr}$-in-Titanite calculations from Fig 14B is displayed, showing that minerals formed on that temperature corroborates with low-temperature deformation. 
Table 3 - Calculated temperatures for quartz c-axis deformation temperatures, based on Faleiros et al. (2016) calibration.

\begin{tabular}{|c|c|c|c|c|}
\hline Unit & Sample & $\begin{array}{l}\text { Opening } \\
\text { Angle }\end{array}$ & $\begin{array}{l}\text { Pressure } \\
\text { (kbar) }\end{array}$ & $\begin{array}{l}\text { Temperature } \\
\left({ }^{\circ} \mathrm{C}\right)\end{array}$ \\
\hline \multirow{2}{*}{$\begin{array}{l}\text { Hornblende-garnet } \\
\text { metatexite }\end{array}$} & \multirow{2}{*}{ CGE-05A (GBM) } & \multirow{2}{*}{$111^{\circ}$} & 1 & 675 \\
\hline & & & 15 & 874 \\
\hline \multirow{10}{*}{$\begin{array}{l}\text { Biotite stromatic } \\
\text { diatexite }\end{array}$} & \multirow{2}{*}{ CGE-03C (BLG) } & \multirow{2}{*}{$75^{\circ}$} & 1 & 515 \\
\hline & & & 15 & 714 \\
\hline & \multirow{2}{*}{ CGE-23B (BLG) } & \multirow{2}{*}{$72^{\circ}$} & 1 & 497 \\
\hline & & & 15 & 697 \\
\hline & \multirow{2}{*}{ CGE-23B (GBM) } & \multirow{2}{*}{$116^{\circ}$} & 1 & 693 \\
\hline & & & 15 & 892 \\
\hline & \multirow{2}{*}{ CGE-33A (GBM) } & \multirow{2}{*}{$108^{\circ}$} & 1 & 664 \\
\hline & & & 15 & 863 \\
\hline & \multirow{2}{*}{ CGE-41A (GBM) } & \multirow{2}{*}{$98^{\circ}$} & 1 & 624 \\
\hline & & & 15 & 823 \\
\hline \multirow{4}{*}{$\begin{array}{c}\text { Três Pontas-Varginha } \\
\text { Nappe }\end{array}$} & \multirow{2}{*}{ CGE-56A (GBM) } & \multirow{2}{*}{$64^{\circ}$} & 1 & 512 \\
\hline & & & 15 & 646 \\
\hline & \multirow{2}{*}{ CGE-46A2 (GBM) } & \multirow{2}{*}{$75^{\circ}$} & 1 & 447 \\
\hline & & & 15 & 711 \\
\hline
\end{tabular}

\section{IV.8 Discussion}

\section{IV.8.1 Physical controls of partial melting and metamorphism}

From the garnet meta-syenogranite, increasing deformation, metamorphism and partial melting transformed the rock into the hornblendegarnet metatexite as described earlier. However, there are still some doubts about the precedence of the stromatic biotite diatexite. It shows biotite as the main mafic mineral, with garnet as an accessory mineral in some samples. This suggests that a high concentration of water in this unit stabilized primarily biotite. The unit also presents increased plagioclase vs K-feldspar ratio in relation to the protolith (A vs $P$ 12:36 and 51:20, respectively). It is possible that this major difference of feldspar proportions indicates that the diatexite does not come from the same protolith, if melting occurred in equilibrium. Still, field evidences point to another direction.

Field structural relationships indicate progressive changes with the correlated increase of deformation intensity and melt fraction. Weakly deformed/metamorphosed garnet meta-syenogranite presents $\sim 3$ vol. $\%$ of random pockets of leucosome that turn into 12 vol.\% of leucosome veins either 
parallel to or that crosscut the mylonite foliation (Fig. 7A), culminating in a stromatic structure where the leucosome reaches 40 vol.\% of the rock in biotite stromatic diatexite (Fig. 16). This relation indicates that deformation exerted a strong control on the partial melt rate. This is reinforced by the fact that dynamic recrystallization of feldspar is more intense in the migmatites dominated by the moderate melt fraction. The presence of the same igneous mineral association in all three rock groups, including K-feldspar large crystals and the accessory minerals, such as allanite, apatite, zircon, and ilmenite corroborate that all rocks have an equivalent protolith, the garnet meta-syenogranite.

In addition, experimental studies by Johannes and Holtz (1992) show that the melting reaction of large plagioclase crystals and a Qtz-Or composed glass produces an unchanged plagioclase core with a reaction zone composed of small crystals of An-rich plagioclase, glass, biotite, and K-feldspar intergrowth. This texture is similar to the one represented in Fig 6A. Experiments on synthetic granite composition, run by Whitney (1975), produced melt in presence of water, at a minimum temperature of $800{ }^{\circ} \mathrm{C}$. The produced melt consumed more $\mathrm{K}$ feldspar and left a plagioclase-rich residuum, in a similar way to the observed rock here. It is also observable in phase relation for biotite-granite generated using natural samples from Dinkey Lakes, where the K-feldspar reacts and leaves the system before plagioclase (Piwinskii, 1968b, 1973; Boettcher and Wyllie, 1968; Stern and Wyllie, 1981), what in a natural system would favor to increase the compositional differences between the original garnet metasyeno-granite and its most extreme derivative, the biotite stromatic diatexite, where it is observed the major difference in bulk composition and feldspars ratio. These processes can change the modal proportion of feldspars during melting, segregation, meltloss, and crystallization history. The differential melting, followed by segregation and melt loss were probably the processes responsible to enhance the impoverishment in K-feldspar in the biotite stromatic diatexite. Thus, field relation between the rocks, accessories minerals, peritetic minerals (discussed below) and experimental data from many different studies corroborate with the hypothesis that the protolith of this unit is the hornblende-garnet metatexite, which started as the meta-syenogranite.

In this model, the bulk-rock composition cannot be considered as the main control of the partial melting variation. In addition, regional metamorphism usually 

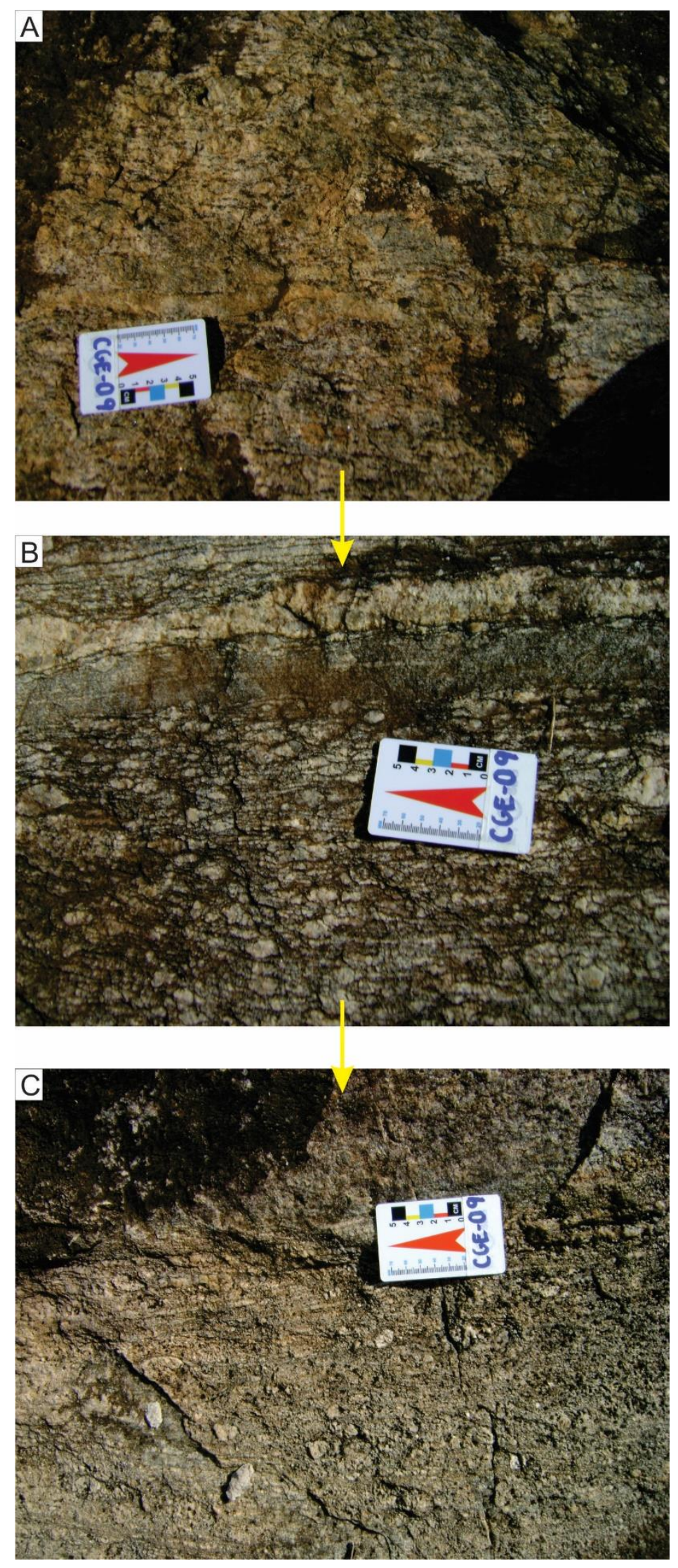

Figure 16 - Sequence of photographs from the outcrop CGE-09 illustrating the transition between the hornblende-garnet metatexite unit $(A)$ to the biotite stromatic diatexite unit $(C)$ passing through a transition section (B). From images (A) to (B), it is possible to observe the comminution of K-feldspar porphyroclasts and the beginning of banding formation. In figure $(\mathrm{C})$ the comminution process is complete, with only a few small porphyroclasts left. 
affects large extensions of the continental crust, which means that temperature and pressure must be similar, or not vary too much, within the investigated region. This consideration allows excluding temperature and pressure as the variables responsible for the heterogeneous amount of melt present in the three subunits. Considering that water facilitates partial melting, as it lowers solidus temperature (e.g., Sawyer, 2010; Weinberg and Hasalová, 2015), and that deformation can facilitate water-influx from external sources (Carvalho et al., 2016), the possible relationship between deformation-assisted water influx and partial melting rates should be investigated. This can be done by considering the modal mineral proportions in the residuum and leucosome from garnet meta-syenogranite, hornblende-garnet metatexite, and biotite stromatic diatexite, in addition to the peritectic mineral phases present in each case.

The peritectic minerals in each rock type, along with modal analysis of the samples, show that water content has a key role in the melting, deformation, and crystallization processes of the Areado Granite-Migmatite Unit. The less deformed garnet meta-syenogranite presents minimal evidence for metamorphism in the form of garnet $+\mathrm{K}$-feldspar \pm plagioclase reaction-rim coronas surrounding rounded (corroded) grains of igneous plagioclase, Kfeldspar, and biotite (Fig. 6A). Plagioclase in these coronas is present as films pseudomorphosing a former melt (Fig. 8A). The following melting reaction can explain these features:

$$
\begin{gathered}
\mathrm{Qtz}+\mathrm{Pl}+\mathrm{Kfs} 1+\mathrm{Bt} 1=\mathrm{Grt}+\mathrm{Kfs} 2+\mathrm{Liq}(1) \\
\mathrm{Ilm}+\mathrm{Pl}+\mathrm{Bt}=\mathrm{Tit}+\mathrm{Bt} 2+\mathrm{Grt}(2)
\end{gathered}
$$

More intensely deformed garnet meta-syenogranite samples present biotite intergrown with garnet and K-feldspar in similar reaction-rim coronas, suggesting the following reaction, which has formed by limited water-influx:

$$
\mathrm{Qtz}+\mathrm{Pl}+\mathrm{Kfs} 1+\mathrm{Bt} 1 \pm \mathrm{H} 2 \mathrm{O}=\mathrm{Grt}+\mathrm{Bt} 2+\mathrm{Kfs} 2+\mathrm{Liq}(3)
$$

The deformed hornblende-garnet metatexite present peritectic hornblende and titanite in addition to garnet, biotite, and K-feldspar, suggesting the following reaction, which also needs limited water-influx: 


$$
\mathrm{Qtz}+\mathrm{Pl}+\mathrm{Kfs} 1+\mathrm{Bt} 1+\mathrm{H} 2 \mathrm{O}=\mathrm{Grt}+\mathrm{Bt} 2+\mathrm{Hbl}+\mathrm{Ttn}+\mathrm{Kfs} 2+\mathrm{Liq}(4)
$$

Idioblastic hornblende can also be found in leucosome veins in the garnet meta-syenogranite unit. These veins collected melt from the edges of K-feldspar and are formed by the same reaction. Locally, partial melting consumed all water and biotite and residuum and leucosome got rid of all biotite and only garnet was produced by reaction 1 .

The presence of hydrated peritectic phases, biotite or hornblende, is good evidence for melting induced by water-influx (e.g., Weinberg and Hasalová, 2015). However, it seems that water influx was limited, as garnet was produced as the only anhydrous phase, in some portions, consuming all biotite, and hornblende is also observed in some localized sites.

The modal analysis also shows evidence of water interference on melt crystallization (Table 2). Data obtained from sixteen samples shows that the hornblende-garnet metatexite presents more K-feldspar in its composition, while the biotite stromatic diatexite presents more plagioclase. This difference in proportion is caused by the amount of water in the system, where the higher content crystallizes more albite than orthoclase (e.g., Tuttle and Bowen, 1958; Luth et al., 1964; Huang and Wyllie, 1975; Holtz et al., 1992c, 1995; Johannes and Holtz, 1996). This implies that after partial melting took place, in the site where the biotite stromatic diatexite was formed, melt loss occurred, and the lost melt carried a composition enriched in K-feldspar components.

The diffusive contact between leucosome and host rock along with the absence of mafic selvedges are morphological characteristics of neosomes generated by water influx (Sawyer, 2010), features also observed in the field. The amount of water injected into the system caused the difference observed. There was more water injection on the east than on the west of the area, and from bottom to top, the degree of partial melting decreased towards the top. The water origin is still unknown, but its access was controlled by deformation, which is quite intense and synchronous with partial melting.

In summary, we believe that both migmatite units came from the garnet meta-syenogranite, but this occurred in steps, first with the formation of the hornblende-garnet metatexite and from it evolving to the biotite stromatic 
diatexite. Each roch shows different melting fractions and melt timing. The hornblende-garnet metatexite was formed by high grade metamorphism and dehydration melt with a small amount of water added to the system, while the biotite stromatic diatexite came later, with a more intense water-influx at the base of the unit, using the already modified hornblende-garnet metatexite as its precursor.

Even if, we cannot rule out the possibility that the biotite stromatic diatexite could be a generated from a different rock, such as the country rock of the garnet meta-syenogranite, as we could not find any zircon with a paleoproterozoic date for a direct connection, although the field relationships are straightforward.

\section{IV.8.2 Structural evolution and thermobarometry}

The structural analysis allowed us to infer that the contact between the Areado Granite-Migmatite Unit and Três Pontas-Varginha Nappe controls the main structures from Alfenas and Areado region. The mylonitic foliation is concordant with the thrust fault, and the kinematic indicators with top to the northwest are inverse to what is observed in the rest of Brasília Orogen, where top movement is primarily to ENE (Campos Neto, 2000; Dardenne, 2000; Valeriano et al., 2004).

Quartz microstructures and quartz c-axis data indicate two deformation mechanism predominance, one of high- and another of lower-temperature, the first mainly related to GBM, whereas the second is associated with BLG recrystallization mechanism. Low-temperature deformation is marked by spaced, millimeter-thick, deformation band cleavage composed of quartz and fine-grained muscovite and epidote. These deformation bands are parallel to the hightemperature mylonitic fabric and cannot be easily distinguished in the field from the high-temperature ones, so they are parallel and define a continuum in deformation processes.

The quartz c-axis thermometer indicates the presence of at least two deformation temperatures, one stage at $\sim 835^{\circ} \mathrm{C}$, and another $\sim 650{ }^{\circ} \mathrm{C}$, both agree with observed quartz microstructures and, although empirical, quartz c-axis seems to produce good temperature intervals for rock deformation. Higher 
temperatures obtained from quartz c-axis analysis in the biotite stromatic diatexite, however, almost overcome the temperature limit of ultra-hightemperature. With $923^{\circ} \mathrm{C}$, it is an unexpected and unlikely result, since it would mean that there should be orthopyroxene in the rock and probably more than 80 $90 \%$ of melt in rock with such composition (Johannes and Holtz, 1996), which is not what is observed in outcrops. In addition, with $80-90 \%$ melt, it is unlikely that grains could still be in contact to deform and no mylonitic foliation would be formed, as it is observed in outcrops. Although no correlation of water activity and quartz opening-angle has been proved experimentally (Law, 2014), some authors have reported that water-saturated systems tend to favor a prism [c] slip over a basal <a> slip, which would increase the opening-angle (e.g. Blumenfeld et al. 1986, Mainprice et al. 1986, Garbutt and Teyssier 1991, Okudaira et al. 1995). Thus, the calculated temperatures of lobated quartz grains in the biotite stromatic diatexite might have been affected by water presence and the calculated temperature might be overestimated.

When associated with the quartz deformation temperatures and the ages of metamorphism, the two deformational textures suggest that the deformation of this rock occurred in a single progressive phase. The crystallization of quartz crystals ruled by GBM processes occurred close to the metamorphic peak of the migmatites, along with the mylonitic foliation and leucosome that filled shear zones. The generation of the low-temperature quartz texture resulted from strain localization in less competent layers of the biotite stromatic diatexite during cooling. This process explains the preservation of lobated quartz crystals in the leucosome and the formation of BLG ruled quartz grains in the residuum of the rock. This conclusion is corroborated by quartz deformation temperatures calculated for the Três Pontas-Varginha Nappe granulite, which already indicate low deformation temperatures during thrusting.

The calculation of metamorphic peak conditions for quartz-feldspathic rocks is not a trivial task, and the application of new thermobarometers using trace elements in minerals seems to be a remarkable tool. However, these thermobarometers are dependent on the saturation of oxides on which they are based. Thus, the use of Ti-in-quartz and Zr-in-titanite on rocks is straightforward when saturated in $\mathrm{TiO} 2$ and $\mathrm{SiO} 2$, which is guaranteed by the free presence of, 
respectively, rutile and quartz (e.g., Zack et al., 2004; Thomas et al., 2010). The garnet meta-syenogranite has abundant free quartz and titanite, but no rutile.

Although all analyses have excellent quality, the TitaniQ thermobarometer has not produced the expected results for $P$ - $T$ metamorphic calculations. The aim is to use this thermobarometer along with $\mathrm{Zr}$-in-titanite to define the $P-T$ conditions of the metamorphic peak, using the double calibration developed by Thomas et al. (2010). The formed intersection by the isopleths of Zr-in-titanite and Ti-in-quartz, using the concentration of the $\mathrm{Zr}$ in the idioblastic titanite crystals, occurs at pressures over $20 \mathrm{kbar}$, which is unrealistic in this geological scenario. One possibility for these results is if the activity of $\mathrm{TiO}_{2}$ is lower than 1 or even lower, such as 0.5 , as advised by authors when titanite is present. Since this rock has no rutile, the $\mathrm{TiO}_{2}$ activity is smaller than 1 , and the approximation of 0.6 given by Hayden et al. (2008) and Hayden and Watson (2007) is not compatible with this rock, and results at such high pressure are assumed to be without petrological meaning ( 950 ${ }^{\circ} \mathrm{C}$ and $31 \mathrm{kbar}$ ).

The difference between the activity of the protolith to the migmatites can be explained by Ti resetting in quartz due to deformation (e.g., Grujic et al., 2011; Ashley et al., 2014; Cavalcante et al., 2014; Bestmann and Pennacchioni, 2015). Ashley et al. (2014) suggest using $\mathrm{TiO}_{2}$ activity equal to 0.2 when the metamorphic rock is intensely deformed. If this value is applied, the results from TitaniQ and Zr-in-titanite of the idioblastic titanite yield an interval between 667$708 \stackrel{\circ}{\mathrm{C}}$ and $11.5-15 \mathrm{kbar}$ for the metamorphic peak (Fig. 10B). This information correlates to the low-temperature deformation obtained by the quartz c-axis, and this has a good petrological and geological appeal. Xenoblastic titanite crystals were formed at $786-815^{\circ} \mathrm{C}$ for the same pressure interval. This data corroborates with high-temperature acquired from GBM formed quartz grains.

Correlating the quartz $\mathrm{c}$-axis thermometer and the other methods suggests that xenoblastic titanite generation crystallized during metamorphic peak (Fig. 10B). It also corroborates the hypothesis that idioblastic titanite occurred together with the low-temperature deformational event. These data are interpreted as two different timing of crystallization and deformation. The older one would reach about $850 \stackrel{\circ}{\circ}$, forming high-temperature deformation quartz crystal and xenoblastic titanite crystals, probably associated with partial melting/metamorphic peak and it is interpreted as a peritectic phase, as pointed 
earlier. Meanwhile, the younger would comprise the formation of idioblastic titanite and low-temperature deformation quartz grains, during melting crystallization or late-stage solid state deformation/metamorphism.

The Ti-in-quartz, Zr-in-titanite, and c-axis deformation thermometer analyses indicate that caution must be taken into account before using trace element thermometers. The two first methods are excellent tools when quartz and rutile are present in the rock that underwent metamorphism under temperatures at or higher than amphibolite facies. When one of the phases is absent, activity calculations for the thermometer application become a problem. Although some authors suggest a fixed $\mathrm{TiO}_{2}$ activity value for certain rocks (e.g., Hayden and Watson, 2007; Ashley et al. 2014), there is no recognized method to calculate the real activity, mainly when quartz deformation is associated (e.g., Grujic et al., 2011; Ashley et al., 2014; Cavalcante et al., 2014; Bestmann and Pennacchioni 2015). The activity variation has induced unusual thermobarometer results on these rocks, such as the high pressures obtained by TitaniQ and Zr-intitanite with $0.5 \mathrm{TiO}_{2}$ activity (Fig. 10A). Quartz c-axis deformation temperature exhibits interesting results for metamorphic rocks. However, the influence of strain rate and water activity on the rock might affect the results, and its influence has not been quantified (Law, 2014; Faleiros et al., 2016). As field and petrography data present evidence that anatexis occurred with water influx on these rocks, the water activity has a significant influence on too high deformation temperature on the biotite stromatic diatexite, probably respond to some of the very high-calculated temperatures, close to $900{ }^{\circ} \mathrm{C}$ (Fig. 15). Even if, as most calculated values are in the range of $830^{\circ} \mathrm{C}$, this value is compatible with the syn-anatectic deformation of this kind of rock and is considered of petrologic importance.

\section{IV.83 Geological history and tectonic evolution of the Areado Unit magmatism and metamorphism}

The garnet meta-syenogranite unit presents preserved igneous textures and its transition to migmatites in the field. Its zircon Concordia dates yielded ages of $2069 \pm 5$ Ma by LA-MC-ICP-MS and $2079 \pm 21$ Ma by SHRIMP, while zircon U-Pb dates from the hornblende-garnet metatexite unit yielded $2083 \pm 12$ Ma and $2075 \pm 23$ Ma for zircon extracted from leucosome from the sample TPR- 
40. Based on the internal textures of the zircon crystals, it is interpreted as the crystallization ages of the igneous protolith of this unit. It shows that this unit protolith is older than the Socorro-Guaxupe Nappe magmatism, which occurred between 730 and $640 \mathrm{Ma}$ (Rocha et al. 2017, 2018; Tedeschi et al., 2018). Also, the crystallization age at the very end of Rhyacian puts this granite outside of what is called the Campos Gerais Complex, which is composed mainly of Archean rocks (Szabó, 1989; Turbay et al., 2008), but it is also younger than most rocks that intrude it (Turbay et al., 2008). Our U-Pb data are closer to the Pouso Alegre Complex (weighted average of $2078.7 \pm 6.7 \mathrm{Ma}$, Cioffi et al., 2016), and indicate that the magmatic event that formed the protolith of the Areado Unit is related to the evolution of the Mineiro Belt.

The Mineiro Belt comprises a Paleoproterozoic orogenic belt with four arctype related orogenies identified ( 2.47-2.41, 2.36-2.33, 2.23-2.20 and 2.172.10 Ga; Seixas et al., 2012, 2013; Ávila et al., 2010, 2014; Barbosa et al., 2015). The protolith of the area shows that the last magmatic event from the accretion of the Mineiro Belt to older rocks from the São Francisco craton is 30 m.y. younger than described in the literature.

The metamorphic $\mathrm{U}-\mathrm{Pb}$ dates obtained from the lower intercept of zircon rims, metamorphic zircon zones, and titanite also evidence that partial melt and metamorphic history of the Areado Unit occurred ca. $600 \mathrm{Ma}$ and is connected to the metamorphic evolution of the Brasilia Orogen. Zircon grains from the garnet meta-syenogranite yielded a lower intercept of $657 \pm 40 \mathrm{Ma}$ and the lower intercept for the grains of hornblende-garnet metatexite is $671 \pm 58 \mathrm{Ma}$. Zircon rims from the biotite stromatic diatexite present Concordia age of $604 \pm 6$ Ma. Titanite was dated in two rocks, garnet meta-syenogranite and hornblendegarnet metatexite, yielding, respectively, $622 \pm 7.0 \mathrm{Ma}$ and $557 \pm 19 \mathrm{Ma}$.

It is considered that the zircon lower intercept represents the closest results for the age of partial melting and metamorphic peak. This data corroborates with high-temperature ages obtained for the Três Pontas-Varginha Nappe (650 Ma for $800^{\circ} \mathrm{C}$, Reno et al., 2009). The younger ages, titanite with $622 \pm 7.0 \mathrm{Ma}$ and $557 \pm 19 \mathrm{Ma}$ would record colling ages, whereas zircon date of $604 \pm 6 \mathrm{Ma}$ from the biotite diatexite records the age of leucosome crystallization. 
Regarding the obtained titanite age, we envisage two possible scenarios for these results. The first model would represent a variation in the metamorphic behavior. The metamorphism from the samples of the protolith is more coherent to an anhydrous melting process, with the generation of water-free phases, such as garnet, while from the migmatites, the major process is a water-fluxed melting. Since zircon and titanite samples from the garnet meta-syenogranite gave an older age cluster (657-621 Ma) and the migmatites present a younger cluster (604 Ma for the biotite diatexite zircons and 557Ma for hornblende-garnet metatexite unit), this age difference can represent the water influx timing. This would mean that the anhydrous metamorphism began earlier than the water entrance at the bottom of the rock package.

The second possibility is that those rocks passed by a long-term cooling process. Although titanite represents a mineral from the metamorphic peak, its age can be more representative of the cooling process, due to its lower closing temperature for the U-Pb system (600-650 ${ }^{\circ} \mathrm{C}$, Mezger et al. 1991, Cherniak, 1993). It would be more likely that data from the garnet meta-syenogranite still marks the last stage of melt crystallization, meanwhile, the age obtained from the hornblende-garnet metatexite represents the age of closure of U-Pb system in titanite after its crystallization. These data agree with the cooling ages found in the literature (620 - $588 \mathrm{Ma}$, Reno et al., 2012). At this stage, melt from the Areado Unit has already crystallized, causing a strain localization on biotite-rich layers and forming the low-temperature quartz deformation fabric.

Since the main metamorphic event occurred during the Neoproterozoic, the Areado Granite-Migmatite Unit should be part of the Southern Brasilia Belt, as the infrastructure of the Andrelândia Nappe System, formed during the collision of the São Francisco and Paranapanema plates and the formation of the Gondwana supercontinent.

A possible tectonic scenario to generate the heat for the metamorphism of these rocks is envisaged here. The Areado Unit is immediately overridden by high-pressure granulites from the Três Pontas-Varginha Nappe, which reached peak metamorphic conditions of $850^{\circ} \mathrm{C}$ and $14-16 \mathrm{kbar}$ (Martinez, 2015), and represents that they might have the same heat source. Reno et al. (2009) report that these rocks were at $800{ }^{\circ} \mathrm{C}$ at $650 \mathrm{Ma}$ in a post-peak 
metamorphic stage. Both data match the metamorphic ages obtained from the zircon lower intercept from the Areado Unit and suggests that this unit was either on the metamorphic peak or on an early stage of cooling at 671-657 Ma. The compilation of these data evidence that the metamorphism of Três PontasVarginha Nappe and the Areado Unit is coeval, and both have the same heat source.

The Areado Unit presented a similar cooling history to the Três PontasVarginha Nappe, associated with melt crystallization. This hypothesis is supported by the zircon metamorphic rims age of $604 \mathrm{Ma}$ that is similar to the ages of $588 \mathrm{Ma}$ for these granulites (Reno et al., 2012).

The migmatites present many indications that they melted in the presence of a restricted amount of water, e.g., hydrated peritectic minerals, extrapolated quartz deformation temperatures, and the lack of selvedges between leucosome and residuum. The amount of water was restricted, as in several portions, the amount of produced melt is restricted, there is an anhydrous peritectic phase, such as garnet, and both features point to restriction to the amount of the fluxed water into the system. However, the source of the fluid that caused partial melt is unknown. The first hypothesis consists of the dehydration of lower metasedimentary units. The water would rise and promote partial melting, at a higher degree at the bottom of the pile, and a lower degree at an intermediate portion. The rocks that received less water, like the garnet meta-syenogranite and the hornblende-garnet metatexite, stabilized hornblende, garnet, and allanite, while the more hydrated rocks biotite and, later, epidote and muscovite. The rocks that are in structural contact with the Areado Unit at its bottom are quartzites, which do not have many hydrous phases and they seem not to be the water source. The shear zone that deforms the rocks was the path for the fluids to get access to the rocks. 


\section{IV.9 Concluding remarks}

The Areado Granite-Migmatite Unit is a complex group of metamorphic rocks that represents the infrastructure of the Southern Brasilia Orogen. Its description and genesis are still in process of investigation, but even with several maps made between Alfenas and Areado, this unit was, until now, not well characterized. Some conclusions are summarized below:

The accessory mineralogy, the K-feldspar porphyroclast, and mainly field relationships suggest that the garnet meta-syenogranite is the protolith of the migmatites described here.

The presence of euhedral hornblende and the absence of selvedges at the border of the leucosome show that the main factor that controlled partial melting on these rocks is the water influx. The upper structural level minimum volume of partial melting is observed, and a major effect of metamorphism occurs on the lower unit instead. The source of the fluid is still unknown. A variation on the mineralogical composition of the biotite stromatic diatexite unit is controlled by the amount of water inserted in the system and deformation.

Structural data indicate the thrust faulting of Três Pontas-Varginha Nappe controls the mylonitic foliation of the area. Fold relationship from the biotite stromatic diatexite unit has at least two deformation stages. Tight folds with the main mylonitic foliation in the axial plane are older than harmonic open folds with the oblique axial plane concerning the main foliation. The correlation of this data with quartz fabric, which presents GBM and BLG recrystallization, suggests that both folds and main foliation were formed during a single deformational event associated with the high-pressure granulite thrust.

Applying quartz c-axis thermometer implied in two deformation temperature intervals, one that represents the metamorphic peak and a lower one. The lobated quartz localized in both migmatite units presents deformation temperatures between 766 and $892^{\circ} \mathrm{C}$, associated with the metamorphic peak in the hornblende-garnet metatexite and partial melt. Quartz grains formed by BLG have deformation temperatures between $613-714^{\circ} \mathrm{C}$, and this temperature range probably marks the stage at which the rock presents enough solid material to underwent solid-state deformation. 
The application of TitaniQ, together with Zr-in-Titanite, did not produce consistent results for these rocks when 0.5 titanium activity was applied. The lack of saturation of titanium in the system, along with its resetting due to deformation, might be the issue. When a $0.2 \mathrm{TiO}_{2}$ activity is used, the metamorphic peak reaches $770-820 \stackrel{\circ}{\mathrm{C}}$ and $11.5-15 \mathrm{kbar}$ for xenoblastic titanites, while idioblastic titanite indicates a cooling temperature of $667-708{ }^{\circ} \mathrm{C}$.

Correlations between the TitaniQ, Zr-in-Titanite, and quartz c-axis thermometers suggest a progressive deformational-metamorphic pulse. Hightemperature deformation on quartz and the formation of xenoblastic titanite crystals, are possibly close to the metamorphic peak and associated with partial melting of the rock. Generation of low-temperature quartz texture and idioblastic titanite crystals, along with mylonitization and folding represents a second event, with lower temperature. The metamorphic ages obtained for this are a low intercept from zircon (671-658 Ma) and titanite $\mathrm{U}-\mathrm{Pb}$ ages of $621 \mathrm{Ma}$ for the garnet meta-syenogranite unit, and zircon age of $604 \mathrm{Ma}$, and younger titanite age of557 Ma for the migmatites. These ages might represent the changes in the melting process, from an anhydrous to water-fluxed melting, or can resemble the cooling history of the unit. This metamorphic event is associated with the thrust of the Southern Brasilia Orogen over the Areado Granite-Migmatite Unit.

Crystallization age of $2.08-2.07 \mathrm{Ga}$ from the garnet meta-syenogranite indicates that it is synchronous to the late stage of magmatic accretion from the Mineiro Belt, similar to what occurs in the Pouso Alegre Complex (weighted average of $2078.7 \pm 6.7 \mathrm{Ma}$, Cioffi et al., 2016). However, its high-grade metamorphism occurred during the Brasiliano Event. Thus, this unit cannot be associated with the Campos Gerais Complex, nor with the Andrelândia Nappe System, as it occurred in some older maps. It should be considered part of the Southern Brasilia Orogen, as part of its infrastructure.

Although most of the obtained data correlate with each other, caution must be taken prior to applying experimental thermometers. The titanium activity calculation is the central issue to use Ti-in-quartz and Zr-in-titanite on metamorphic rocks when rutile is not present. Although the literature suggests a small value for titanium activity, new ways to calculate it must be investigated. 
Water activity seems to affect some results for GBM quartz analysis, causing an overestimation of high deformation temperature.

\section{IV.10 Acknowledgments}

Financial support came from grants 13/04007-0, 16/22627-3, and 18/10012-0, São Paulo Research Foundation (FAPESP). The authors recognize the collaboration by Edward W. Sawyer on fieldwork. Acknowledgments are also given to José Vinícius Martins and Sandra Andrade from NAP Geoanalítica for their assistance with LA-ICP-MS analysis. We also appreciated the aid from Kei Sato on the SHRIMP proceedings. Finally, we appreciate the aid from Valdecir de Assis Janasi, Geane Carolina Cavalcante for their critical reviews. Daniel do Valle Lemos Santos and Lucas Martins Lino Aguiar dos Santos for their assistance during revision. The main author is a CNPq (Conselho Nacional de Desenvolvimento Científico e Tecnológico) research fellow and thanks CNPq and CAPES (Coordenação de Aperfeiçoamento de Pessoal de Nível Superior) for their support. RM and FMF are CNPq Research Fellows, grants 305720/2020-1 and 307732/2019-3, respectively.

\section{IV.11 References}

Alkmim, F.F., Teixeira, W., 2017. The Paleoproterozoic Mineiro Belt and the Quadrilátero Ferrífero, in: Heilbron, M., Cordani, U.G., Alkmim, F.F. (Eds.), São Francisco Craton, Eastern Brazil. Regional Geology Reviews. Springer, Charm, pp. 71-94. https://doi.org/10.1007/978-3-319-01715-0_5

Alkmim, F.F., 1993. Arcabouço tectônico do cráton de São Francisco, uma revisão, in: III Simpósio do Cráton do São Francisco. pp. 45-62.

Almeida, F.F.M. de, 1981. O Cráton do Paramirim e suas relações com o do São Francisco, in: Simpósio Do Cráton Do São Francisco e Suas Faixas Marginais. pp. 1-10.

Artur, A.C., 1988. Evolução policiclíca da infra-estrutura da porção sul do estado de Minas Gerais e regiões adjacentes do estado de São Paulo. Universidade 
de São Paulo.

Ashley, K.T., Carlson, W.D., Law, R.D., Tracy, R.J., 2014. Ti resetting in quartz during dynamic recrystallization: Mechanisms and significance. Am. Mineral. 99, 2025-2030. https://doi.org/10.2138/am-2014-4943

Ávila, C.A., Teixeira, W., Bongiolo, E.M., Dussin, I.A., Vieira, T.A.T., 2014. Rhyacian evolution of subvolcanic and metasedimentary rocks of the southern segment of the Mineiro belt, São Francisco Craton, Brazil. $\begin{array}{llll}\text { Precambrian } & \text { Res. 221-251. }\end{array}$ https://doi.org/10.1016/j.precamres.2013.12.028

Ávila, C.A., Teixeira, W., Cordani, U.G., Moura, C.A.V., Pereira, R.M., 2010. Rhyacian (2.23-2.20 Ga) juvenile accretion in the southern São Francisco craton, Brazil: Geochemical and isotopic evidence from the Serrinha magmatic suite, Mineiro belt. J. South Am. Earth Sci. 29, 464-482. https://doi.org/10.1016/J.JSAMES.2009.07.009

Ávila, C.A., Teixeira, W., Cordani, U.G., Barrueto, H.R., Pereira, R.M., Martins, V.T.S., Dunyi, L., 2006. The Glória quartz-monzodiorite: Isotopic and chemical evidence of arc-related magmatism in the central part of the paleoproterozoic Mineiro belt, Minas Gerais State, Brazil. An. Acad. Bras. Cienc. 78, 543-556. https://doi.org/10.1590/S0001-37652006000300013

Barbosa, N.S., Teixeira, W., Ávila, C.A., Montecinos, P.M., Bongiolo, E.M., 2015. 2.17-2.10Ga plutonic episodes in the Mineiro belt, São Francisco Craton, Brazil: U-Pb ages, geochemical constraints and tectonics. Precambrian Res. 270, 204-225. https://doi.org/10.1016/j.precamres.2015.09.010

Bea, F., 1996. Residence of REE, Y, Th and $U$ in granites and crustal protoliths; implications for the chemistry of crustal melts. J. Petrol. 37, 521-552. https://doi.org/10.1093/petrology/37.3.521

Bestmann, M., Pennacchioni, G., 2015. Ti distribution in quartz across a heterogeneous shear zone within a granodiorite: The effect of deformation mechanism and strain on $\mathrm{Ti}$ resetting. Lithos 227, 37-56. https://doi.org/10.1016/j.lithos.2015.03.009

Blumenfeld, P., Mainprice, D., Bouchez, J.L., 1986. C-slip in quartz from subsolidus deformed granite. Tectonophysics 127, 97-115.

Brito-Neves, B.B. de, Campos-Neto, M. da C., Fuck, R.A., 1999. From Rodinia to western Gondwana; an approach to the Brasiliano-Pan African cycle and 
orogenic collage. Episodes 22, 155-166.

Boettcher, A. L., \& Wyllie, P. J., 1968. Melting of Granite with Excess Water to 30

Kilobars Pressure. The Journal of Geology, 76(2), 235-244. doi:10.1086/627324

Campos, M.T.R., 2015. Nappe Guaxupé e Sistema de Nappes Andrelândia na Região de Alfenas, sul de Minas Gerais. Universidade Federal do Rio de Janeiro, RJ. Masters Dissertation.

Campos Neto, M. da C., 2000. Orogenic systems from SW-Gondwana: an approach to Braziliano-Pan African cycle and orogenic collage in SE-Brazil, in: Cordani, U., Thomaz F ilho, A., Milani, E. (Ed.), Proceedings of the 31st International Geological Congress on the Tectonic Evolution of South America. Rio de Janeiro, pp. 335-365.

Campos Neto, M. da C., Caby, R., 2000. Terrane accretion and upward extrusion of high-pressure granulites in the Neoproterozoic nappes of southeast Brazil: Petrologic and structural constraints. Tectonics 19, 669-687. https://doi.org/10.1029/1999TC900065

Campos Neto, M. da C., Janasi, V. de A., Stipp Basei, M.A., Siga, O., 2007. Sistema de nappes Andrelândia, setor oriental: litoestratigrafia e posição estratigráfica. Revista Brasileira de Geociências. 37, 47-60.

Campos Neto, M. da C., Cioffi, C.R., Moraes, R., da Motta, R.G., Siga, O., Basei, M.A.S., 2010. Structural and metamorphic control on the exhumation of highP granulites: The Carvalhos Klippe example, from the oriental Andrelândia Nappe System, southern portion of the Brasília Orogen, Brazil. Precambrian Res. 180, 125-142. https://doi.org/10.1016/j.precamres.2010.05.010

Campos Neto, M. da C., Stipp Basei, M.A., Janasi, V. de A., Moraes, R. De, 2011.

Orogen migration and tectonic setting of the Andrelândia Nappe system: An Ediacaran western Gondwana collage, south of São Francisco craton. J. $\begin{array}{lllll}\text { South } & \text { Am. }\end{array}$ https://doi.org/10.1016/j.jsames.2011.02.006

Campos Neto, M.D.C., Caby, R., 1999. Neoproterozoic high-pressure metamorphism and tectonic constraint from the nappe system south of the Sao Francisco Craton, southeast Brazil. Precambrian Res. 97, 3-26. https://doi.org/10.1016/S0301-9268(99)00010-8

Carvalho, B.B., Sawyer, E.W., Janasi, V.A., 2016. Crustal reworking in a shear 
zone: Transformation of metagranite to migmatite. J. Metamorph. Geol. 34, 237-264. https://doi.org/10.1111/jmg.12180

Cavalcante, G.C.G., Vauchez, A., Merlet, C., Egydio-Silva, M., De Holanda, M.H.B., Boyer, B., 2014. Thermal conditions during deformation of partially molten crust from TitaniQ geothermometry: Rheological implications for the anatectic domain of the Araçuaí belt, eastern Brazil. Solid Earth 5, $1223-$ 1242. https://doi.org/10.5194/se-5-1223-2014

Cavalcante, J.C., Cunha, H.C. da S., Chieregati, L.A., Kaefer, L.Q., Rocha, J.M. da, Daitx, E.C., Coutinho, M.G. da N., Hama, M., Yamamoto, K., Drumond, J.B.V., Rosa, D.B., Ramalho, R., 1977. Projeto Sapucaí - Relatório Final Geologia Volume I. São Paulo.

Cherniak, D.J., 1993. Lead diffusion in titanite and preliminary results on the effects of radiation damage on Pb transport. Chem. Geol. 110, 177-194. https://doi.org/10.1016/0009-2541(93)90253-F

Cioffi, C.R., Campos Neto, M. da C., Möller, A., Rocha, B.C., 2016. Paleoproterozoic continental crust generation events at 2.15 and $2.08 \mathrm{Ga}$ in the basement of the southern Brasília Orogen, SE Brazil. Precambrian Res. 275, 176-196. https://doi.org/10.1016/j.precamres.2016.01.007

D'Agrella-Filho, M.S., Cordani, U.G., 2017. The Paleomagnetic Record of the São Francisco-Congo Craton, in: Heilbron, M., Alkmim, F., Cordani, U.G. (Eds.), The São Francisco Craton and Its Margins, Eastern Brazil. pp. 305320. https://doi.org/10.1007/978-3-319-01715-0_16

D'Ágrella-Filho, M.S., Pacca, I.I.G., 1998. Paleomagnetism of Paleoproterozoic mafic dyke swarm from the Uauá region, northeastern São Francisco Craton, Brazil: tectonic implications. J. South Am. Earth Sci. 11, 23-33. https://doi.org/10.1016/S0895-9811(97)00034-5

D’Agrella-Filho, M.S., Trindade, R.I.F., Tohver, E., Janikian, L., Teixeira, W., Hall, C., 2011. Paleomagnetism and 40Ar/39Ar geochronology of the high-grade metamorphic rocks of the Jequié block, São Francisco Craton: Atlantica, Ur and beyond. Precambrian Res. 185, 183-201. https://doi.org/10.1016/j.precamres.2011.01.008

Dardenne, M.A., 2000. The Brasilia Fold Belt, in: CORDANI, U.G., Milani, E.J., Thomaz Filho, A., Campos, D.A. (Eds.), Proceedings of the 31st International Geological Congress on the Tectonic Evolution of South America. Rio de 
Janeiro, pp. 231-263.

Deer, W.A., Howie, R.A., Zussman, J., 1992. An introduction to the rock-forming minerals. Longman Scientific \& Technical, Hong Kong.

Faleiros, F.M., Moraes, R., Pavan, M., Campanha, G.A.C., 2016. A new empirical calibration of the quartz c-axis fabric opening-angle deformation thermometer. Tectonophysics 671, 173-182. https://doi.org/10.1016/j.tecto.2016.01.014

Finger, F., Broska, I., Roberts, M.P., Schermaier, A., 1998. Replacement of primary monazite by apatite-allanite-epidote coronas in an amphibolite facies granite gneiss from the eastern Alps. Am. Mineral. 83, 248-258. https://doi.org/10.2138/am-1998-3-408

Fuck, R.A., Pimentel, M.M., Silva, L., 1994. Compartimentação tectônica da porção oriental da Província Tocantins, in: Congresso Brasileiro de Geologia. SBG, Camboriú, pp. 215-216.

Garbutt, J.M., Teyssier, C., 1991. Prism [c] slip in the quartzites of the Oakhurst Mylonite Belt, California. J. Struct. Geol. 13, 657-666.

Garcia, M. da G.M., Campos Neto, M. da C., 2003. Contrasting metamorphic conditions in the Neoproterozoic São Francisco Craton , SE Brazil collisionrelated Nappes south of Sa. J. South Am. Earth Sci. 15, 853-870.

Grujic, D., Stipp, M., Wooden, J.L., 2011. Thermometry of quartz mylonites: Importance of dynamic recrystallization on Ti-in-quartz reequilibration. Geochemistry, Geophys. Geosystems 12, 1-19. https://doi.org/10.1029/2010GC003368

Hayden, L.A., Watson, E.B., 2007. Rutile saturation in hydrous siliceous melts and its bearing on Ti-thermometry of quartz and zircon. Earth Planet. Sci. Lett. 258, 561-568. https://doi.org/10.1016/j.epsl.2007.04.020

Hayden, L.A., Watson, E.B., Wark, D.A., 2008. A thermobarometer for sphene (titanite). Contrib. to Mineral. Petrol. 155, 529-540. https://doi.org/10.1007/s00410-007-0256-y

Heilbron, M., Cordani, U.G., Alkmim, F.F., 2017. The São Francisco Craton and Its Margins, in: Heilbron, M., Cordani, U.G., Alkmim, F.F. (Eds.), São Francisco Craton, Eastern Brazil. Regional Geology Reviews. SpringerVerlag, Cham, pp. 3-13. https://doi.org/10.1007/978-3-319-01715-0_1 
Holness, M.B., Sawyer, E.W., 2008. On the Pseudomorphing of Melt-filled Pores During the Crystallization of Migmatites. J. Petrol. 49, 1343-1363. https://doi.org/10.1093/petrology/egn028

Holtz, F., Behrens, H., Dingwell, D.B., Johannes, W., 1995. H 2 O solubility in haplogranitic melts; compositional, pressure, and temperature dependence. Am. Mineral. 80, 94-108. https://doi.org/10.2138/am-1995-1-210

Holtz, F., Pichavant, M., Barbey, P., Johannes, W., 1992. Effects of H2O on liquidus phase relations in the haplogranite system at 2 and $5 \mathrm{kbar}$. Am. Mineral. 77, 1223-1241.

Huang, W.-L., Wyllie, P.J., 1975. Melting Reactions in the System NaAISi 3 O 8 -KAISi 3 O 8 -SiO 2 to 35 Kilobars, Dry and with Excess Water. J. Geol. 83, 737-748. https://doi.org/10.1086/628165

Johannes, W., Holtz, F., 1992. Melting of plagioclase in granite and related systems: composition of coexisting phases and kinetic observations. Trans R Soc Edinb Earth Sci. 83, 417422 doi:10.1017/S0263593300008087

Johannes, W., Holtz, F., 1996. Petrogenesis and Experimental Petrology of Granitic Rocks, Minerals and Rocks. Springer Berlin Heidelberg, Berlin, Heidelberg. https://doi.org/10.1007/978-3-642-61049-3

Kruhl, J.H., 1996. Prism- and basal-plane parallel subgrain boundaries in quartz: a microstructural geothermobaromether. J. Metamorph. Geol. 14, 581-589. https://doi.org/10.1046/j.1525-1314.1996.00413.x

Law, R.D., 2014. Deformation thermometry based on quartz c-axis fabrics and recrystallization microstructures: A review. J. Struct. Geol. 66, 129-161. https://doi.org/10.1016/j.jsg.2014.05.023

Loios, V.A.P., 2004. Laboratório de preparação e separação de minerais - Centro de Pesquisas Geocronológicas - IGC - USP, in: Simpósio 40 Anos de Geocronologia No Brasil. CPGeo/IGc-USP, São Paulo, SP.

Ludwig, K.R., 2003. User's manual for isoplot 3.00, a geochronlogical toolkit for microsoft excel. Berkeley Geochronl. Cent. Spec. Publ. 4, 25-32.

Luth, W.C., Jahns, R.H., Tuttle, O.F., 1964. The granite system at pressures of 4 to 10 kilobars. J. Geophys. Res. 69, 759-773. https://doi.org/10.1029/JZ069i004p00759

Mainprice, D., Bouchez, J.-L., Blumenfeld, P., Tobia, J.M., 1986. Dominant C-slip in naturally deformed quartz: implications for dramatic plastic softening at 
high temperature. Geology 14, 819-822.

Martinez, R.B., 2015. Avaliação de métodos para cálculo e inferência de condições P-T em rochas da fácies granulito: investigação das rochas das Nappes Três Pontas-Varginha e Socorro-Guaxupé. University of Sao Paulo. Masters Dissertation

Marchildon, N., Brown, M., 2002. Grain-scale melt distribution in two contact aureole rocks: implications for controls on melt localization and deformation.

J. Metamorph. Geol. 20, 381-396. https://doi.org/10.1046/j.15251314.2002.00376.x

Mezger, K., Rawnsley, C.M., Bohlen, S.R., Hanson, G.N., 1991. U-Pb Garnet, Sphene, Monazite, and Rutile Ages: Implications for the Duration of HighGrade Metamorphism and Cooling Histories, Adirondack Mts., New York. J. Geol. 99, 415-428. https://doi.org/10.1086/629503

Moraes, R., Nicollet, C., Barbosa, J.S.F., Fuck, R.A., Sampaio, A.R., 2015. Applications and limitations of thermobarometry in migmatites and granulites using as an example rocks of the Araçuaí Orogen in southern Bahia, including a discussion on the tectonic meaning of the current results. Brazilian J. Geol. 45, 517-539. https://doi.org/10.1590/23174889201520150026

Morales, N., Carvalho, S.G., Choudhuri, A., Fiori, A.P., Oliveira, M.A.F., Rodrigues, M.F.B., Soares, P.C., Zanardo, A., 1983. Geologia das folhas de Fortaleza de Minas, Alpinópolis, Jacuí e Nova Resende, MG, in: Anais Do $2^{\circ}$ Simpósio de Geologia de Minas Gerais. Sociedade Brasileira de Geologia, Belo Horizonte, MG, pp. 411-422.

Morgan, S.S., Law, R.D., 2004. Unusual transition in quartzite dislocation creep regimes and crystal slip systems in the aureole of the Eureka Valley-Joshua Flat-Beer Creek pluton, California: a case for anhydrous conditions created by decarbonation reactions. Tectonophysics 384, 209-231. https://doi.org/10.1016/j.tecto.2004.03.016

Motta, R.G., Moraes, R., 2017. Pseudo- and real-inverted metamorphism caused by the superposition and extrusion of a stack of nappes: a case study of the Southern Brasília Orogen, Brazil. Int. J. Earth Sci. 106, 2407-2427. https://doi.org/10.1007/s00531-016-1436-7

Noce, C.M., Teixeira, W., Quéméneur, J.J.G., Martins, V.T.S., Bolzachini, É., 
2000. Isotopic signatures of Paleoproterozoic granitoids from the southern Sao Francisco Craton and implications for the evolution of the Transamazonian Orogeny. J. South Am. Earth Sci. 13, 225-239. https://doi.org/10.1016/S0895-9811(00)00019-5

Okudaira, T., Takeshita, T., Hara, I., Ando, J.-I., 1995. A new estimate of the conditions for transition from basal $<\mathrm{a}>$ to prism [c] slip in naturally deformed quartz. Tectonophysics 250, 31-46.

Piwinskii, A. J., 1968. Experimental Studies of Igneous Rock Series Central Sierra Nevada Batholith, California. The Journal of Geology, 76(5), 548-570. doi:10.1086/627359

Piwinskii, A.J., 1973. Experimental studies of granitoids from the Central and Southern Coast Ranges, California. TMPM Tschermaks Petr. Mitt. 20, 107130. https://doi.org/10.1007/BF01081387

Reno, B.L., Brown, M., Kobayashi, K., Nakamura, E., Piccoli, P.M., Trouw, R.A.J., 2009. Eclogite - High-pressure granulite metamorphism records early collision in West Brasília Belt , Brazil Gondwana: new data from the Southern Brasil. J. Geol. Soc. London. 166, 1013-1032. https://doi.org/10.1144/001676492008-140.

Reno, B.L., Piccoli, P.M., Brown, M., Trouw, R.A.J., 2012. In situ monazite ( U Th )- $\mathrm{Pb}$ ages from the Southern Brası Brazil: constraints on the hightemperature retrograde evolution of HP granulites 81-112. https://doi.org/10.1111/j.1525-1314.2011.00957.x

Ribeiro, A., Campos, M.T., Paciullo, F.B., Carvalho, M.C., Valeriano, C., Nascimento, D., 2014. Mapa Geológico Preliminar - Folha Alfenas - SF-23V-D-II. Rio de Janeiro. Escala 1:100.000.

Rocha, B.C., Moraes, R., Möller, A., Cioffi, C.R., 2018. Magmatic inheritance vs. UHT metamorphism: Zircon petrochronology of granulites and petrogenesis of charnockitic leucosomes of the Socorro-Guaxupé nappe, SE Brazil. Lithos 314-315, 16-39. https://doi.org/10.1016/j.lithos.2018.05.014

Rocha, B.C., Moraes, R., Möller, A., Cioffi, C.R., Jercinovic, M.J., 2017. Timing of anatexis and melt crystallization in the Socorro-Guaxupé Nappe, SE Brazil: Insights from trace element composition of zircon, monazite and garnet coupled to UPb geochronology. Lithos 277, 337-355. https://doi.org/10.1016/J.LITHOS.2016.05.020 
Sato, K., Basei, M.A.S., Júnior, O.S., Sproesser, W.M., Passarelli, C.R., 2008. Novas técnicas aplicadas ao método U-Pb no CPGeo - IGc/USP: Avanços na digestão química, espectrometria de massa (TIMS) e exemplos de aplicação integrada com SHRIMP. Geol. USP - Ser. Cient. 8, 77-99.

Sato, K., Tassinari, C.C.G., Basei, M.A.S., Siga Júnior, O., Onoe, A.T., Souza, M.D. de, 2014. Sensitive High Resolution Ion Microprobe (SHRIMP IIe/MC) of the Institute of Geosciences of the University of São Paulo, Brazil: analytical method and first results. Geol. USP. Série Científica 14, 3-18. https://doi.org/10.5327/Z1519-874X201400030001

Sawyer, E.W., 2010. Migmatites formed by water-fluxed partial melting of a leucogranodiorite protolith: Microstructures in the residual rocks and source of the fluid. Lithos 116, 273-286. https://doi.org/10.1016/j.lithos.2009.07.003 Sawyer, E.W., 2008. Atlas of Migmatites, The Canadian Mineralogist Special Publication 9. NRC Research Press, Ottawa.

Sawyer, E.W., 2001. Melt segregation in the continental crust: distribution and movement of melt in anatectic rocks. J. Metamorph. Geol. 19, 291-309. https://doi.org/10.1046/j.0263-4929.2000.00312.x

Sawyer, E.W., 1999. Criteria for the recognition of partial melting. Phys. Chem. Earth, Part A Solid Earth Geod. 24, 269-279. https://doi.org/10.1016/S14641895(99)00029-0

Schrank, A., Abreu, F.R., Roig, H.L., Choudhuri, A., Szabó, G.A.J., Carvalho, E.D.R., 1990. Determinacao dos vetores de transporte tectonico na borda sudoeste do craton do sao francisco, in: Anais Do Congresso Brasileiro de Geologia. Sociedade Brasileira de Geologia, Natal, RN, pp. 2276-2283.

Seixas, L.A.R., Bardintzeff, J.-M., Stevenson, R., Bonin, B., 2013. Petrology of the high-Mg tonalites and dioritic enclaves of the ca. 2130Ma Alto Maranhão suite: Evidence for a major juvenile crustal addition event during the Rhyacian orogenesis, Mineiro Belt, southeast Brazil. Precambrian Res. 238, 18-41. https://doi.org/10.1016/j.precamres.2013.09.015

Seixas, L.A.R., David, J., Stevenson, R., 2012. Geochemistry, Nd isotopes and $\mathrm{U}-\mathrm{Pb}$ geochronology of a 2350Ma TTG suite, Minas Gerais, Brazil: Implications for the crustal evolution of the southern São Francisco craton. $\begin{array}{llll}\text { Precambrian } & \text { Res. 196-197, }\end{array}$ 
https://doi.org/10.1016/j.precamres.2011.11.002

Stern, C. R., \& Wyllie, P. J., 1981. Phase relationships of I-type granite with $\mathrm{H} 2 \mathrm{O}$ to 35 kilobars: The Dinkey Lakes biotite-granite from the Sierra Nevada Batholith. Journal of Geophysical Research: Solid Earth, 86(B11), 1041210422. doi:10.1029/jb086ib11p10412

Szabó, G.A.J., 1996. Petrologia da Suíte Metaultramáfica da Seqüência VulcanoSedimentar Morro do Ferro na região sul a oeste de Alpinópolis, MG (domínio norte do Complexo Campos Gerais).

Szabó, G.A.J., 1989. Contexto geológico e petrologia das rochas metaultramáficas de Alpinopolis, MG. Universidade de São Paulo, São Paulo. https://doi.org/10.11606/D.44.1989.tde-22042013-162400

Tedeschi, M., Pedrosa-Soares, A., Dussin, I., Lanari, P., Novo, T., Pinheiro, M.A.P., Lana, C., Peters, D., 2018. Protracted zircon geochronological record of UHT garnet-free granulites in the Southern Brasília orogen (SE Brazil): Petrochronological constraints on magmatism and metamorphism. $\begin{array}{llll}\text { Precambrian } & \text { Res. 316, 103-126. }\end{array}$ https://doi.org/10.1016/J.PRECAMRES.2018.07.023

Teixeira, N.A., Gaspar, J.C., Brenner, T.L., Cheney, J.T., Marchetto, C.M.L., 1987. Geologia e implicações geotectônicas do Greenstone Belt Morro do Ferro (Fortaleza de Minas, MG). Rev. Bras. Geociencias 17, 209-220.

Teixeira, W., Ávila, C.A., Dussin, I.A., Corrêa Neto, A. V., Bongiolo, E.M., Santos, J.O., Barbosa, N.S., 2015. A juvenile accretion episode (2.35-2.32Ga) in the Mineiro belt and its role to the Minas accretionary orogeny: Zircon U-Pb-Hf and geochemical evidences. Precambrian Res. 256, 148-169. https://doi.org/10.1016/j.precamres.2014.11.009

Teixeira, W., Sabaté, P., Barbosa, J.S.F., Carneiro, M., 2000. Archean and Paleoproterozoic tectonic evolution of the Sao Francisco craton, Brazil, in: Cordani, U.G., Milani, E.J., Thomaz Filho, A., Campos, A.D. (Eds.), Tectonic Evolution of South America. 31. International Geological Congress, Rio de Janeiro, pp. 101-137.

Thomas, J.B., Watson, E.B., Spear, F.S., Shemella, P.T., Nayak, S.K., Lanzirotti, A., 2010. TitaniQ under pressure: The effect of pressure and temperature on the solubility of Ti in quartz. Contrib. to Mineral. Petrol. 160, 743-759. https://doi.org/10.1007/s00410-010-0505-3 
Trouw, R.A.J., Castro, E.M., 1996. Significado tectônico de granulitos Brasilianos de alta pressão no sul de Minas Gerais, in: $39^{\circ}$ Congresso Brasileiro de Geologia. SBG, Salvador, BA, pp. 145-148.

Trouw, R.A.J., Castro, E.M.O., Trouw, C.C., Matos, G.C., 2008. Nota explicativa das folhas Varginha (SF. 23-VD-VI)e Itajubá (SF. 23-YB-III). Programa Geol. do Bras. 99.

Trouw, R.A.J., Heilbron, M., Ribeiro, A., Paciullo, F.V.P., Valeriano, C.M., Almeida, J.C.H., Tupinambá, M., Andreis, R.R., 2000. The central segment of the Ribeira Belt, in: Cordani, U., Thomaz F ilho, A., Milani, E. (Ed.), Proceedings of the 31st International Geological Congress on the Tectonic Evolution of South America. CPRM, Rio de Janeiro, pp. 287-310.

Turbay, C.V.G., 2010. Caracterização petrológica e geocronológica do Complexo Campos Gerais (Arqueano / Paleoproterozóico), Minas Gerais, Brasil. Universidade do Estado do Rio de Janeiro, RJ. PhD Thesis.

Turbay, C.V.G., Valeriano, C.M., Rossi, A., Rocha e Silva, V.G.M., 2008. Geologia do complexo Campos Gerais ao sul de Alpinópolis, sudoeste de Minas Gerais. Geonomos 16, 79-90.

Tuttle O.F., Bowen N.L., 1958. Origin of granite in the light of experimental studies in the system NaAISi308-KAISi308-Si02-H20. Geological Society of America.

Valeriano, C. de M., 2017. The Southern Brasília Belt, in: HEILBRON, M., CORDANI, U.G., ALKMIM, F.F. (Eds.), São Francisco Craton, Eastern Brazil. Regional Geology Reviews. Springer International Publishing, pp. 189-203. https://doi.org/10.1007/978-3-319-01715-0_10

Valeriano, C. de M., Dardenne, M.A., Fonseca, M.A., Simões, L.S.A., Seer, H.J., 2004. A evolução tectônica da Faixa Brasília, in: Mantesso-Neto, V., Bartorelli, A., Carneiro, C.D.R., Brito Neves, B.B. (Eds.), Geologia Do Continente Sul-Americano: Evolução Da Obra de Fernando Flávio Marques de Almeida. Beca, São Paulo, SP, pp. 575-592.

Valeriano, C.M., Simonetti, A., Turbay, C., Rossi, A., Nogueira, J.R., 2006. U-Pb zircon ages by LA-MCICPMS from orthogneisses south of Alpinópolis (Minas Gerais, SE-Brazil): reconstructing Paleoproterozoic cratons on the southwestern margin of the São Francisco paleocontinent, in: GACMAC Annual Meeting. 
Weinberg, R.F., Hasalová, P., 2015. Water-fluxed melting of the continental crust: A review. Lithos 212-215, 158-188. https://doi.org/10.1016/j.lithos.2014.08.021

Westin, A., Campos Neto, M.C., Hawkesworth, C.J., Cawood, P.A., Dhuime, B., Delavault, H., 2016. A paleoproterozoic intra-arc basin associated with a juvenile source in the Southern Brasilia Orogen: Application of $\mathrm{U}-\mathrm{Pb}$ and $\mathrm{Hf}-$ $\mathrm{Nd}$ isotopic analyses to provenance studies of complex areas. Precambrian Res. 276, 178-193. https://doi.org/10.1016/J.PRECAMRES.2016.02.004

Westin, A., Campos Neto, M.D.C., 2013. Provenance and tectonic setting of the external nappe of the Southern Brasília Orogen. J. South Am. Earth Sci. 48, 220-239. https://doi.org/10.1016/j.jsames.2013.08.006

Whitney, A.J., 1975. The Effects of Pressure, Temperature, and XH2O on Phase Assemblage in Four Synthetic Rock Compositions. J. Geol. 83, 1-31.

Zack, T., Moraes, R., Kronz, A., 2004. Temperature dependence of $Z r$ in rutile: empirical calibration of a rutile thermometer. Contrib. to Mineral. Petrol. 148, 471-488. https://doi.org/10.1007/s00410-004-0617-8 


\section{Chapter V - Final Considerations}

The Areado Granite-Migmatite Unit is a complex block that had never had detailed research on it before this project to actually identify its geological framework and petrological evolution. In some maps, it was associated with the Campos Gerais complex (Cavalcante et al., 1979; Artur, 1988). This work has set the correct classification of each rock inside the unit, along with the geological process that generated such a different partial melt rate inside the same region, and has contextualized the granite emplacement and the metamorphism in time.

Modal analysis shows that a big variation in the QAP proportion between the meta-syenogranite and the migmatites but the petrography and field relations clearly indicates that they are cogenetic. The answer of that matter was found in experimental petrology, where several experiments (e.g. Piwinskii, 1968b, 1973; Boettcher and Wyllie, 1968; Stern and Wyllie, 1981; Whitney, 1975) have got similar results when applying partial melting with high $a_{\mathrm{H}_{2} \mathrm{O}}$ in the samples. That fact, associated with the hydrated peritectic minerals in all units and the diffusive contact between leucosome and the residuum points to the water-assisted melting as the main metamorphic process that affected these rocks. It is also interesting to point out that the presence of garnet as a peritectic mineral in both meta-syenogranite and metatexite and mostly absence in the diatexite suggests a variation in the amount of water that caused melting in each rock. The meta-syenogranite had low to no addition of water in the system, while the metatexite received a low amount and the diatexite was saturated on it.

The application of different thermobarometry methods was successful with some problems to consider. The quartz c-axis proved to be a useful tool to understand the thermal evolution of rocks, exhibiting the temperature difference on deformation zones. The main issue is the temperature calculation on rocks that have a high $a_{\mathrm{H}_{2} \mathrm{O}}$. As stated by Law (2014) and Faleiros et al. (2016), the increase of water in the system can cause an over estimative of the deformation temperatures, and this study also saw this event happening. It is necessary more research on the effect of water on quartz dislocation creep and a new calibration to avoid this issue. The use of TitaniQ and $\mathrm{Zr}$ - 
in-titanite together to estimate the metamorphic peak of the Areado unit created some interesting results and can be indicated for this type of rock, especially when thermodynamic modeling failed, which was the case. However, a big pitfall can be the $a_{\mathrm{TiO}_{2}}$ estimative on metamorphic rocks since both thermobarometers depend on them. When the sample present rutile, it is safe to assume that the $a_{\mathrm{TiO}_{2}}$ is equivalent to one, but when it doesn't present the mineral, it becomes tricky to define the activity of the system. Hayden et al. (2008) suggested the use of 0.6 for rocks with granitic composition, but that assumption proved to be inefficient with the Areado unit. It is possible that the deformation and partial melt might change the Ti concentration on metamorphic quartz grains and change the activity as consequence.

Dating the migmatites permitted us to understand better the geological context of the Areado Unit. Crystallization ages of $2069.8 \pm 5$ Ma proved that the protolith of the migmatites was generated at the last stages of the Mineiro Belt generation. Lower intercepts from zircon indicate a metamorphic and partial melting age between $671 \pm$ 58 and $657 \pm 40 \mathrm{Ma}$ and the melt crystallization ages of $622 \pm 7 \mathrm{Ma}$ and $604 \pm 6 \mathrm{Ma}$ shows that these rocks were reworked during the Brasilia Orogenic Event and from now on, this unit should be considered as part of the Southern Brasilia Orogen. 


\section{Chapter VI - References}

Alkmim, F.F., Teixeira, W., 2017. The Paleoproterozoic Mineiro Belt and the Quadrilátero Ferrífero, in: Heilbron, M., Cordani, U.G., Alkmim, F.F. (Eds.), São Francisco Craton, Eastern Brazil. Regional Geology Reviews. Springer, Charm, pp. 71-94. https://doi.org/10.1007/978-3-319-01715-0_5

Almeida, F.F.M. de, 1981. O Cráton do Paramirim e suas relações com o do São Francisco, in: Simpósio Do Cráton Do São Francisco e Suas Faixas Marginais. pp. 1-10.

Artur, A.C., 1988. Evolução policiclíca da infra-estrutura da porção sul do estado de Minas Gerais e regiões adjacentes do estado de São Paulo. Universidade de São Paulo.

Ávila, C.A., Teixeira, W., Bongiolo, E.M., Dussin, I.A., Vieira, T.A.T., 2014. Rhyacian evolution of subvolcanic and metasedimentary rocks of the southern segment of the Mineiro belt, São Francisco Craton, Brazil. Precambrian Res. 243, 221-251. https://doi.org/10.1016/j.precamres.2013.12.028

Ávila, C.A., Teixeira, W., Cordani, U.G., Barrueto, H.R., Pereira, R.M., Martins, V.T.S., Dunyi, L., 2006. The Glória quartz-monzodiorite: Isotopic and chemical evidence of arc-related magmatism in the central part of the paleoproterozoic Mineiro belt, Minas Gerais State, Brazil. An. Acad. Bras. Cienc. 78, 543-556. https://doi.org/10.1590/S0001-37652006000300013

Barbosa, N.S., Teixeira, W., Ávila, C.A., Montecinos, P.M., Bongiolo, E.M., 2015. 2.172.10Ga plutonic episodes in the Mineiro belt, São Francisco Craton, Brazil: U-Pb ages, geochemical constraints and tectonics. Precambrian Res. 270, 204-225. https://doi.org/10.1016/j.precamres.2015.09.010

Boettcher, A. L., \& Wyllie, P. J., 1968. Melting of Granite with Excess Water to 30 Kilobars Pressure. The Journal of Geology, 76(2), 235-244. doi:10.1086/627324

Brito-Neves, B.B. de, Campos-Neto, M. da C., Fuck, R.A., 1999. From Rodinia to western Gondwana; an approach to the Brasiliano-Pan African cycle and orogenic collage. Episodes 22, 155-166.

Campos, J.C.S., Carneiro, M.A., 2008. Neoarchean and Paleoproterozoic granitoids marginal to the Jeceaba-Bom Sucesso lineament (SE border of the southern São Francisco craton): Genesis and tectonic evolution. J. South Am. Earth Sci. 26, 
463-484. https://doi.org/10.1016/J.JSAMES.2008.09.002

Campos Neto, M. da C., 2000. Orogenic systems from SW-Gondwana: an approach to Braziliano-Pan African cycle and orogenic collage in SE-Brazil, in: Cordani, U., Thomaz F ilho, A., Milani, E. (Ed.), Proceedings of the 31st International Geological Congress on the Tectonic Evolution of South America. Rio de Janeiro, pp. 335-365.

Campos Neto, M. da C., Caby, R., 2000. Terrane accretion and upward extrusion of high-pressure granulites in the Neoproterozoic nappes of southeast Brazil: Petrologic and structural constraints. Tectonics 19, 669-687. https://doi.org/10.1029/1999TC900065

Campos Neto, M. da C., Cioffi, C.R., Moraes, R., da Motta, R.G., Siga, O., Basei, M.A.S., 2010. Structural and metamorphic control on the exhumation of high-P granulites: The Carvalhos Klippe example, from the oriental Andrelândia Nappe System, southern portion of the Brasília Orogen, Brazil. Precambrian Res. 180, 125-142. https://doi.org/10.1016/j.precamres.2010.05.010

Campos Neto, M. da C., Stipp Basei, M.A., Farias Vlach, S.R., Caby, R., Szabó, G.A.J., Vasconcelos, P., 2004. Migração de Orógenos e Superposição de Orogêneses: Um Esboço da Colagem Brasiliana no Sul do Cráton do São Francisco, SE Brasil. Geol. USP - Ser. Cient. 4, 13-40. https://doi.org/10.5327/S1519874X2004000100002

Campos Neto, M. da C., Stipp Basei, M.A., Janasi, V. de A., Moraes, R. De, 2011. Orogen migration and tectonic setting of the Andrelândia Nappe system: An Ediacaran western Gondwana collage, south of São Francisco craton. J. South Am. Earth Sci. 32, 393-406. https://doi.org/https://doi.org/10.1016/j.jsames.2011.02.006

Cavalcante, J.C., Cunha, H.C. da S., Chieregati, L.A., Kaefer, L.Q., Rocha, J.M. da, Daitx, E.C., Coutinho, M.G. da N., Hama, M., Yamamoto, K., Drumond, J.B.V., Rosa, D.B., Ramalho, R., 1979. Projeto Sapucaí - Relatório Final Geologia Volume I. São Paulo.

Cherniak, D.J., 2006. Zr diffusion in titanite. Contribution to Mineral Petrology, 152, 639-647.

Cherniak, D.J., Watson, E. B., Wark, D. A., 2007. Ti diffusion in quartz. Chemical Geology, 236, 65-74.

Cioffi, C.R., Campos Neto, M. da C., Möller, A., Rocha, B.C., 2016. Paleoproterozoic 
continental crust generation events at 2.15 and $2.08 \mathrm{Ga}$ in the basement of the southern Brasília Orogen, SE Brazil. Precambrian Res. 275, 176-196. https://doi.org/10.1016/j.precamres.2016.01.007

Dardenne, M.A., 2000. The Brasilia Fold Belt, in: CORDANI, U.G., Milani, E.J., Thomaz Filho, A., Campos, D.A. (Eds.), Proceedings of the 31st International Geological Congress on the Tectonic Evolution of South America. Rio de Janeiro, pp. 231263.

Deer, W.A., Howie, R.A., Zussman, J., 1992. An introduction to the rock-forming minerals. Longman Scientific \& Technical, Hong Kong.

Faleiros, F.M., Moraes, R., Pavan, M., Campanha, G.A.C., 2016. A new empirical calibration of the quartz $\mathrm{C}$-axis fabric opening-angle deformation thermometer. Tectonophysics $671,173-182$. https://doi.org/10.1016/j.tecto.2016.01.014

Fuck, R.A., Pimentel, M.M., Alvarenga, C.J.S., Dantas, E.L., 2017. The Northen Brasília Belt, in: Heilbron, M., Cordani, U.G., Alkmim, F.F. (Eds.), São Francisco Craton, Eastern Brazil. Regional Geology Reviews. Springer, Charm, pp. 205220. https://doi.org/10.1007/978-3-319-01715-0_11

Fuck, R.A., Pimentel, M.M., Silva, L., 1994. Compartimentação tectônica da porção oriental da Província Tocantins, in: Congresso Brasileiro de Geologia. SBG, Camboriú, pp. 215-216.

Garcia, M. da G.M., Campos Neto, M. da C., 2003. Contrasting metamorphic conditions in the Neoproterozoic São Francisco Craton, SE Brazil collision-related Nappes south of Sa. J. South Am. Earth Sci. 15, 853-870.

Hayden, L.A., Watson, E.B., Wark, D.A., 2008. A thermobarometer for sphene (titanite). Contrib. to Mineral. Petrol. 155, 529-540. https://doi.org/10.1007/s00410-007-0256-y

Heilbron, M., Cordani, U.G., Alkmim, F.F., 2017. The São Francisco Craton and Its Margins, in: Heilbron, M., Cordani, U.G., Alkmim, F.F. (Eds.), São Francisco Craton, Eastern Brazil. Regional Geology Reviews. Springer-Verlag, Cham, pp. 3-13. https://doi.org/10.1007/978-3-319-01715-0_1

Janasi, V. de A., 2002. Elemental and $\mathrm{Sr}-\mathrm{Nd}$ isotope geochemistry of two Neoproterozoic mangerite suites in SE Brazil: implications for the origin of the mangerite-charnockite-granite series. Precambrian Res. 119, 301-327. https://doi.org/10.1016/S0301-9268(02)00127-4

Kruhl, J. H., 1986. Textures and c-axis orientations of deformed quartz crystals 
fromporphyric dikes of the Alpine 'Root Zone' (Western Alps). Geologisch. Rundsch. 75,601-623.

Kruhl, J. H., 1996. Prism- and basal-plane parallel subgrain boundaries in quartz: a microstructural geothermobarometer. Journal of Metamorphic Geology. 14, 581 589.

Kruhl, J. H., 1998. Reply: Prism- and basal-plane parallel subgrain boundaries in quartz: a microstructural geothermobarometer. Journal of Metamorphic Geology, $16,142-146$.

Law, R.D., 2014. Deformation thermometry based on quartz c-axis fabrics and recrystallization microstructures: A review. J. Struct. Geol. 66, 129-161. https://doi.org/10.1016/j.jsg.2014.05.023

Loios, V.A.P., 2004. Laboratório de preparação e separação de minerais - Centro de Pesquisas Geocronológicas - IGC - USP, in: Simpósio 40 Anos de Geocronologia No Brasil. CPGeo/IGc-USP, São Paulo, SP.

Martinez, R.B., 2015. Avaliação de métodos para cálculo e inferência de condições P$T$ em rochas da fácies granulito: investigação das rochas das Nappes Três Pontas-Varginha e Socorro-Guaxupé. University of Sao Paulo. Masters Dissertation

Moraes, R., Brown, M., Fuck, R. a., Camargo, M.A., Lima, T.M., 2002. Characterization and P-T Evolution of Melt-bearing Ultrahigh-temperature Granulites: an Example from the Anapolis-Itaucu Complex of the Brasilia Fold Belt, Brazil. J. Petrol. 43, 1673-1705. https://doi.org/10.1093/petrology/43.9.1673

Moraes, R., Nicollet, C., Barbosa, J.S.F., Fuck, R.A., Sampaio, A.R., 2015. Applications and limitations of thermobarometry in migmatites and granulites using as an example rocks of the Araçuaí Orogen in southern Bahia, including a discussion on the tectonic meaning of the current results. Brazilian J. Geol. 45, 517-539. https://doi.org/10.1590/2317-4889201520150026

Morales, N., Carvalho, S.G., Choudhuri, A., Fiori, A.P., Oliveira, M.A.F., Rodrigues, M.F.B., Soares, P.C., Zanardo, A., 1983. Geologia das folhas de Fortaleza de Minas, Alpinópolis, Jacuí e Nova Resende, MG, in: Anais Do $2^{\circ}$ Simpósio de Geologia de Minas Gerais. Sociedade Brasileira de Geologia, Belo Horizonte, MG, pp. 411-422.

Moreira, H., Seixas, L., Storey, C., Fowler, M., Lasalle, S., Stevenson, R., Lana, C., 2018. Evolution of Siderian juvenile crust to Rhyacian high Ba-Sr magmatism in 
the Mineiro Belt, southern São Francisco Craton. Geosci. Front. 9, 977-995. https://doi.org/10.1016/j.gsf.2018.01.009

Motta, R.G., Moraes, R., 2017. Pseudo- and real-inverted metamorphism caused by the superposition and extrusion of a stack of nappes: a case study of the Southern Brasília Orogen, Brazil. Int. J. Earth Sci. 106, 2407-2427. https://doi.org/10.1007/s00531-016-1436-7

Noce, C.M., Teixeira, W., Quéméneur, J.J.G., Martins, V.T.S., Bolzachini, É., 2000. Isotopic signatures of Paleoproterozoic granitoids from the southern Sao Francisco Craton and implications for the evolution of the Transamazonian Orogeny. J. South Am. Earth Sci. 13, 225-239. https://doi.org/10.1016/S08959811(00)00019-5

Passchier, C.W., Trouw, R.A.J., 2005. Microtectonics, 2nd ed, Tectonophysics. Springer-Verlag, Berlin/Heidelberg. https://doi.org/10.1007/3-540-29359-0

Peternel, R., Trouw, R.A.J., Schmitt, R.D.S., 2005. Interferência Entre Duas Faixas Móveis Neoproterozóicas: O Caso Das Faixas Brasília E Ribeira No Sudeste Do Brasil. Rev. Bras. Geociências 35, 297-310.

Pimentel, M.M., 2016. The tectonic evolution of the Neoproterozoic Brasília Belt, central Brazil: a geochronological and isotopic approach. Brazilian J. Geol. 46, 67-82. https://doi.org/10.1590/2317-4889201620150004

Piwinskii, A. J., 1968. Experimental Studies of Igneous Rock Series Central Sierra Nevada Batholith, California. The Journal of Geology, 76(5), 548-570. doi:10.1086/627359

Piwinskii, A.J., 1973. Experimental studies of granitoids from the Central and Southern Coast Ranges, California. TMPM Tschermaks Petr. Mitt. 20, 107-130. https://doi.org/10.1007/BF01081387

Reno, B.L., Brown, M., Kobayashi, K., Nakamura, E., Piccoli, P.M., Trouw, R.A.J., 2009. Eclogite - High-pressure granulite metamorphism records early collision in West Brasília Belt, Brazil Gondwana: new data from the Southern Brasil. J. Geol. Soc. London. 166, 1013-1032. https://doi.org/10.1144/0016-76492008140.Eclogite

Rocha, B.C., Moraes, R., Möller, A., Cioffi, C.R., 2018. Magmatic inheritance vs. UHT metamorphism: Zircon petrochronology of granulites and petrogenesis of charnockitic leucosomes of the Socorro-Guaxupé nappe, SE Brazil. Lithos 314315, 16-39. https://doi.org/10.1016/j.lithos.2018.05.014 
Rocha, B.C., Moraes, R., Möller, A., Cioffi, C.R., Jercinovic, M.J., 2017. Timing of anatexis and melt crystallization in the Socorro-Guaxupé Nappe, SE Brazil: Insights from trace element composition of zircon, monazite and garnet coupled to $\quad \mathrm{UPb}$ geochronology. Lithos 277, 337-355. https://doi.org/10.1016/J.LITHOS.2016.05.020

Schrank, A., Abreu, F.R., Roig, H.L., Choudhuri, A., Szabó, G.A.J., Carvalho, E.D.R., 1990. Determinacao dos vetores de transporte tectonico na borda sudoeste do craton do sao francisco, in: Anais Do Congresso Brasileiro de Geologia. Sociedade Brasileira de Geologia, Natal, RN, pp. 2276-2283.

Stern, C. R., \& Wyllie, P. J., 1981. Phase relationships of I-type granite with $\mathrm{H} 2 \mathrm{O}$ to 35 kilobars: The Dinkey Lakes biotite-granite from the Sierra Nevada Batholith. Journal of Geophysical Research: Solid Earth, 86(B11), 10412-10422. doi:10.1029/jb086ib11p10412

Stipp, M., Stünitz, H., Heilbronner, R., Schmid, S.M., 2002. Dynamic recrystallization of quartz: correlation between natural and experimental conditions. Geol. Soc. London, Spec. Publ. 200, 171-190. https://doi.org/10.1144/GSL.SP.2001.200.01.11

Szabó, G.A.J., 1996. Petrologia da Suíte Metaultramáfica da Seqüência VulcanoSedimentar Morro do Ferro na região sul a oeste de Alpinópolis, MG (domínio norte do Complexo Campos Gerais).

Szabó, G.A.J., 1989. Contexto geológico e petrologia das rochas metaultramáficas de Alpinopolis, MG. Universidade de São Paulo, São Paulo. https://doi.org/10.11606/D.44.1989.tde-22042013-162400

Tedeschi, M., Pedrosa-Soares, A., Dussin, I., Lanari, P., Novo, T., Pinheiro, M.A.P., Lana, C., Peters, D., 2018. Protracted zircon geochronological record of UHT garnet-free granulites in the Southern Brasília orogen (SE Brazil): Petrochronological constraints on magmatism and metamorphism. Precambrian Res. 316, 103-126. https://doi.org/10.1016/J.PRECAMRES.2018.07.023

Teixeira, N.A., Gaspar, J.C., Brenner, T.L., Cheney, J.T., Marchetto, C.M.L., 1987. Geologia e implicações geotectônicas do Greenstone Belt Morro do Ferro (Fortaleza de Minas, MG). Rev. Bras. Geociencias 17, 209-220.

Teixeira, W., Akimoto, H., Siga Júnior, O., Sato, K., 1989. Evolucao geocronologica dos terrenos granitico-gnaissicomigmatiticos ao sul da faixa canastra, sudoeste de minas gerais. Simp. Geol. Nucl. Minas Gerais. 
Teixeira, W., Ávila, C.A., Dussin, I.A., Corrêa Neto, A. V., Bongiolo, E.M., Santos, J.O., Barbosa, N.S., 2015. A juvenile accretion episode (2.35-2.32Ga) in the Mineiro belt and its role to the Minas accretionary orogeny: Zircon U-Pb-Hf and geochemical evidences. Precambrian Res. 256, 148-169. https://doi.org/10.1016/j.precamres.2014.11.009

Teixeira, W., Figueiredo, M.C.H., 1991. An outline of Early Proterozoic crustal evolution in the São Francisco craton, Brazil: a review. Precambrian Res. 53, $1-$ 22. https://doi.org/10.1016/0301-9268(91)90003-S

Teixeira, W., Oliveira, E.P., Peng, P., Dantas, E.L., Hollanda, M.H.B.M., 2017. U-Pb geochronology of the $2.0 \mathrm{Ga}$ Itapecerica graphite-rich supracrustal succession in the São Francisco Craton: Tectonic matches with the North China Craton and paleogeographic inferences. Precambrian Res. 293, 91-111. https://doi.org/10.1016/J.PRECAMRES.2017.02.021

Thomas, J.B., Watson, E.B., Spear, F.S., Shemella, P.T., Nayak, S.K., Lanzirotti, A., 2010. TitaniQ under pressure: The effect of pressure and temperature on the solubility of $\mathrm{Ti}$ in quartz. Contrib. to Mineral. Petrol. 160, 743-759. https://doi.org/10.1007/s00410-010-0505-3

Trouw, R.A.J., Castro, E.M., 1996. Significado tectônico de granulitos Brasilianos de alta pressão no sul de Minas Gerais, in: $39^{\circ}$ Congresso Brasileiro de Geologia. SBG, Salvador, BA, pp. 145-148.

Trouw, R.A.J., Castro, E.M.O., Trouw, C.C., Matos, G.C., 2008. Nota explicativa das folhas Varginha (SF. 23-VD-VI)e Itajubá (SF. 23-YB-III). Programa Geol. do Bras. 99.

Trouw, R.A.J., Heilbron, M., Ribeiro, A., Paciullo, F.V.P., Valeriano, C.M., Almeida, J.C.H., Tupinambá, M., Andreis, R.R., 2000. The central segment of the Ribeira Belt, in: Cordani, U., Thomaz F ilho, A., Milani, E. (Ed.), Proceedings of the 31st International Geological Congress on the Tectonic Evolution of South America. CPRM, Rio de Janeiro, pp. 287-310.

Turbay, C.V.G., Valeriano, C.M., 2012. Litogeoquímica do Complexo Campos Gerais e granitoides intrusivos, Arqueano/Paleoproterozoico, Brasil. Rev. Bras. Geociências 42, 663-689. https://doi.org/10.5327/Z0375-75362012000400003

Turbay, C.V.G., Valeriano, C.M., Rossi, A., Rocha e Silva, V.G.M., 2008. Geologia do complexo Campos Gerais ao sul de Alpinópolis, sudoeste de Minas Gerais. Geonomos 16, 79-90. 
Valeriano, C.M., Simonetti, A., Turbay, C., Rossi, A., Nogueira, J.R., 2006. U-Pb zircon ages by LA-MCICPMS from orthogneisses south of Alpinópolis (Minas Gerais, SE-Brazil): reconstructing Paleoproterozoic cratons on the southwestern margin of the São Francisco paleocontinent, in: GACMAC Annual Meeting.

Wark, D. A., Watson, E. B. (2006) TitaniQ: a titanium-in-quartz geothermometer. Contributions to Mineral Petrology, 152, 743-754.

Wernick, E., Artur, A.C., Fiori, A.P., 1981. Reavaliação de dados geocronológicos da região NE do estado de São Paulo e unidades correlatas no estado de Minas Gerais e Rio de Janeiro. An. do Simpósio Reg. Geol. SBG, Curitiba 328-332.

Westin, A., Campos Neto, M.C., Hawkesworth, C.J., Cawood, P.A., Dhuime, B., Delavault, H., 2016. A paleoproterozoic intra-arc basin associated with a juvenile source in the Southern Brasilia Orogen: Application of $\mathrm{U}-\mathrm{Pb}$ and $\mathrm{Hf}-\mathrm{Nd}$ isotopic analyses to provenance studies of complex areas. Precambrian Res. 276, 178193. https://doi.org/10.1016/J.PRECAMRES.2016.02.004

Westin, A., Campos Neto, M.D.C., 2013. Provenance and tectonic setting of the external nappe of the Southern Brasília Orogen. J. South Am. Earth Sci. 48, 220 239. https://doi.org/10.1016/j.jsames.2013.08.006

Whitney, A.J., 1975. The Effects of Pressure, Temperature, and XH2O on Phase Assemblage in Four Synthetic Rock Compositions. J. Geol. 83, 1-31. 
Apendix 
Table A 1 - ICP-MS analysis on quartz grains in the hornblende-garnet metatexite unit

\begin{tabular}{|c|c|c|c|c|c|c|c|c|c|}
\hline \multicolumn{10}{|c|}{ Sample ALFE - 24} \\
\hline ppm & Crystal 1 & Crystal 2 & Crystal 3 & Crystal 4 & Crystal 5 & Crystal 6 & Crystal 7 & Crystal 8 & Crystal 9 \\
\hline Li6 & 2.21 & 3.13 & $<3.32$ & $<1.69$ & 2.68 & $<2.28$ & $<1.08$ & $<3.22$ & $<1.19$ \\
\hline $\mathrm{Li} 7$ & 1.45 & 2.35 & $<0.70$ & 0.47 & 2.05 & 2.49 & $<0.21$ & $<0.51$ & 0.43 \\
\hline $\mathrm{Na} 23$ & 10.1 & 59.35 & 26.16 & $<6.73$ & $<10.24$ & $<10.54$ & $<7.55$ & $<18.91$ & $<8.13$ \\
\hline Al27 & 45.77 & 21.06 & 170 & 7.93 & 94.9 & 38.84 & 13.88 & 59.95 & 19.56 \\
\hline Si29 & 467434 & 467434 & 467434 & 467434 & 467434 & 467434 & 467434 & 467434 & 467434 \\
\hline Si30 & 392236 & 407811 & 503934 & 425029 & 384035 & 502665 & 595054 & 562864 & 373202 \\
\hline Ca42 & 321 & $<157$ & 1720 & $<253$ & 380 & 791 & $<255$ & $<622$ & 354 \\
\hline Ca43 & $<117$ & $<70.27$ & $<390$ & $<108$ & $<159$ & $<165$ & $<111$ & $<290$ & $<117$ \\
\hline Ca44 & 1348 & 2148 & 3620 & 1106 & 1022 & 1629 & 2056 & 1093 & 1163 \\
\hline Ti49 & 2.78 & 3.04 & 4.27 & 4.73 & 2.63 & 2.38 & 3.54 & 3.49 & 2.63 \\
\hline Mn55 & $<0.23$ & $<0.134$ & $<0.78$ & $<0.22$ & $<0.31$ & $<0.31$ & $<0.23$ & $<0.54$ & $<0.229$ \\
\hline Fe56 & 13.11 & $<2.07$ & 289 & 8.61 & 11.11 & 11.06 & 3.92 & $<8.04$ & 6.36 \\
\hline $\mathrm{Fe} 57$ & $<12.02$ & $<7.13$ & 227 & $<11.64$ & $<17.25$ & $<17.38$ & $<11.39$ & $<29.58$ & $<12.14$ \\
\hline Zn66 & 4.34 & 2.43 & 3.67 & 1.82 & 6.37 & 2.43 & $<0.64$ & 3.11 & 2.68 \\
\hline Ga69 & 0.042 & 0.05 & 0.515 & 0.16 & $<0.075$ & $<0.061$ & 0.048 & $<0.130$ & $<0.056$ \\
\hline Ge70 & 0.44 & 0.63 & 0.97 & 0.55 & 0.5 & 0.27 & 1 & 0.76 & 0.58 \\
\hline Ga71 & $<0.032$ & $<0.019$ & 0.391 & 0.4 & $<0.049$ & 0.054 & 0.306 & 0.285 & 0.191 \\
\hline Ge72 & 0.56 & 0.63 & 3.26 & 1.04 & $<0.77$ & $<0.73$ & 0.86 & 2.02 & 0.73 \\
\hline Ge73 & 0.51 & 0.48 & 3.23 & $<0.312$ & 0.66 & 0.59 & 1.33 & 2.38 & 1.01 \\
\hline Ge74 & 0.44 & 0.64 & 1.15 & 0.71 & 0.65 & 0.46 & 0.79 & $<0.59$ & 0.4 \\
\hline Se77 & $<1.77$ & $<1.21$ & $<6.02$ & $<1.89$ & $<2.59$ & $<2.90$ & $<2.31$ & $<3.46$ & $<1.61$ \\
\hline $\mathrm{Rb} 85$ & 0.043 & 0.03 & 0.097 & $<0.040$ & 0.04 & 0.051 & $<0.034$ & $<0.072$ & $<0.044$ \\
\hline Zr90 & 0.059 & 0.08 & $<0.063$ & $<0.038$ & 0.084 & 0.042 & 0.034 & $<0.064$ & $<0.024$ \\
\hline Ba138 & 0.174 & 0.366 & 0.84 & $<0.039$ & 0.855 & 0.209 & 0.134 & 0.272 & 0.213 \\
\hline Pb208 & 0.111 & 0.056 & 0.207 & 0.06 & 0.105 & 0.149 & 0.101 & 0.241 & 0.079 \\
\hline
\end{tabular}


Table A 2- ICP-MS analysis on quartz grains in the biotite stromatic diatexite unit

\begin{tabular}{|c|c|c|c|c|c|c|c|c|}
\hline $\begin{array}{l}\text { Sample CGE-03D } \\
\text { ppm }\end{array}$ & Crystal 1 & Crystal 2a & Crystal 2b & Crystal 3 & Crystal 4 & Crystal 5 & Crystal $6 a$ & Crystal 6b \\
\hline Li6 & 1.33 & $<0.37$ & $<0.47$ & 0.62 & $<0.53$ & $<0.43$ & $<0.62$ & $<0.43$ \\
\hline Li7 & 1.047 & $<0.088$ & $<0.105$ & 0.786 & 0.231 & $<0.089$ & 0.22 & 0.144 \\
\hline $\mathrm{Na} 23$ & 35.05 & 11.17 & 24.04 & 40.34 & 9.45 & 18.8 & 40.27 & 22.35 \\
\hline $\mathrm{Al} 27$ & 48.81 & 46.54 & 38.55 & 62 & 7.23 & 26.65 & 51.71 & 50 \\
\hline Si29 & 467434 & 467434 & 467434 & 467434 & 467434 & 467434 & 467434 & 467434 \\
\hline $\mathrm{Si} 30$ & 479120 & 458431 & 531086 & 479427 & 476160 & 448245 & 438233 & 476920 \\
\hline Ca42 & $<20.63$ & $<29.88$ & 52.26 & $<28.69$ & $<36.44$ & 29.21 & $<39.23$ & $<34.04$ \\
\hline Ca43 & 18.29 & 82.33 & 26.54 & 43.25 & $<15.51$ & 31.77 & 30.28 & 40.3 \\
\hline Ca44 & 1334 & 2149 & 1564 & 1223 & 1569 & 1594 & 1074 & 1489 \\
\hline Ti49 & 5.08 & 3.29 & 3.73 & 4.54 & 3.82 & 4.23 & 5.13 & 5.1 \\
\hline Mn55 & 0.451 & 0.447 & 0.215 & 0.391 & $<0.036$ & 0.144 & 0.284 & 0.34 \\
\hline Fe56 & 38.04 & 17.93 & 12.83 & 50.62 & 9.62 & 28.44 & 49.98 & 42.01 \\
\hline Fe57 & 26.9 & 14.61 & 15.94 & 57.69 & 2.16 & 26.41 & 41.52 & 49.49 \\
\hline Zn66 & 1.74 & 1.83 & 0.67 & 1.47 & 0.3 & 0.669 & 1.11 & 1.53 \\
\hline Ga69 & 0.0524 & 0.042 & 0.219 & 0.0636 & 0.054 & 0.239 & 0.018 & 0.0602 \\
\hline Ge70 & 0.825 & 0.99 & 1.79 & 1.02 & 0.88 & 0.924 & 0.87 & 0.811 \\
\hline Ga71 & 0.0306 & 0.154 & 0.078 & 0.095 & 0.208 & 0.176 & 0.049 & 0.087 \\
\hline Ge72 & 0.827 & 1.22 & 1.035 & 0.854 & 1.48 & 1 & 1.01 & 1.14 \\
\hline Ge73 & 0.971 & 1.15 & 1.47 & 0.941 & 2.58 & 1.26 & 0.87 & 1.46 \\
\hline Ge74 & 0.854 & 0.762 & 0.977 & 0.996 & 1.016 & 0.985 & 0.914 & 0.956 \\
\hline Se77 & $<0.133$ & $<0.21$ & 0.54 & $<0.216$ & $<0.26$ & 0.16 & $<0.26$ & $<0.21$ \\
\hline Rb85 & 0.0605 & 0.05 & 0.0373 & 0.419 & 0.0206 & 0.0496 & 0.162 & 0.186 \\
\hline Zr90 & 0.0423 & 0.0258 & 410 & 0.265 & 0.0072 & 0.0139 & 0.0267 & 0.053 \\
\hline Ba138 & 0.574 & 1.165 & 0.234 & 0.605 & 0.0725 & 0.633 & 1.046 & 0.585 \\
\hline $\mathrm{Pb} 208$ & 0.1194 & 0.185 & 0.0625 & 0.413 & 0.0345 & 0.0966 & 0.154 & 0.174 \\
\hline
\end{tabular}


Table A 3 - ICP-MS analysis on titanite grains at the hornblende-garnet metatexite unit

\begin{tabular}{|c|c|c|c|c|c|c|c|c|}
\hline $\begin{array}{l}\text { Sample } \\
\text { ppm }\end{array}$ & Tit1 & Tit2 & Tit3 & Tit4 & Tit5 & Tit6 & Tit7 & Tit5b \\
\hline Li7 & 0.64 & $<0.46$ & $<0.45$ & 0.71 & 1.11 & 0.75 & 1.19 & $<0.56$ \\
\hline Mg24 & 105 & 109 & 99.47 & 76.92 & 258 & 107 & 102 & 179 \\
\hline Al27 & 23430 & 26844 & 22877 & 22374 & 27004 & 23582 & 20831 & 22412 \\
\hline Si29 & 137283 & 151585 & 142098 & 135450 & 138056 & 134161 & 132170 & 133513 \\
\hline P31 & 132 & 176 & 132 & 113 & 88.42 & 125 & 123 & 59.46 \\
\hline Ca42 & 201150 & 212260 & 206025 & 201076 & 195883 & 206697 & 192695 & 204689 \\
\hline Ca44 & 192397 & 192397 & 192397 & 192397 & 192397 & 192397 & 192397 & 192397 \\
\hline Sc45 & 11.3 & 12.72 & 11.27 & 11.26 & 31.34 & 12.74 & 12.01 & 27.55 \\
\hline Ti46 & 157894 & 153169 & 160423 & 158903 & 150503 & 155139 & 169963 & 162284 \\
\hline Ti49 & 179707 & 175054 & 182191 & 185861 & 174690 & 177512 & 194157 & 190469 \\
\hline V51 & 5.23 & 4.19 & 5.63 & 4.09 & 10.85 & 5.37 & 5.08 & 13.05 \\
\hline Cr52 & $<0.33$ & 0.78 & 0.42 & 0.37 & 1.97 & 0.45 & 0.51 & 2.25 \\
\hline Mn55 & 75.09 & 75.05 & 72.2 & 74.59 & 545 & 71.98 & 70.7 & 173 \\
\hline Fe56 & 6940 & 6639 & 7432 & 6450 & 15667 & 6820 & 7307 & 12317 \\
\hline Co59 & $<0.024$ & 0.081 & $<0.021$ & 0.048 & 0.091 & 0.048 & $<0.018$ & 0.061 \\
\hline Sr88 & 50.83 & 63.33 & 59.06 & 75.15 & 23.04 & 56.04 & 56.5 & 34.9 \\
\hline Y89 & 2341 & 2409 & 1980 & 1321 & 13722 & 1733 & 2024 & 12640 \\
\hline Zr91 & 93.69 & 75.15 & 69.35 & 49.22 & 667 & 61.95 & 74.34 & 612 \\
\hline Nb93 & 3852 & 4159 & 3859 & 3831 & 3344 & 4032 & 4304 & 3761 \\
\hline Sn118 & 124 & 136 & 128 & 95.61 & 81.35 & 115 & 134 & 103 \\
\hline Sb121 & $<0.048$ & $<0.050$ & $<0.048$ & $<0.049$ & $<0.050$ & $<0.056$ & $<0.048$ & $<0.059$ \\
\hline Ba137 & 0.782 & 1.99 & 0.381 & 0.439 & 0.25 & 1.64 & 0.599 & 0.59 \\
\hline La139 & 40.52 & 112 & 23.95 & 17.84 & 595 & 38.6 & 32.38 & 232 \\
\hline Ce140 & 222 & 412 & 182 & 115 & 3658 & 158 & 177 & 1645 \\
\hline $\operatorname{Pr} 141$ & 65.31 & 98.85 & 57.27 & 34.61 & 881 & 49.91 & 56.06 & 471 \\
\hline Nd143 & 545 & 729 & 510 & 291 & 5920 & 418 & 476 & 3701 \\
\hline Sm147 & 419 & 502 & 410 & 246 & 2431 & 333 & 361 & 1886 \\
\hline Eu151 & 116 & 122 & 105 & 74.62 & 141 & 91.96 & 103 & 130 \\
\hline Gd157 & 687 & 786 & 650 & 418 & 2581 & 529 & 623 & 2247 \\
\hline Tb159 & 143 & 158 & 132 & 86.89 & 487 & 104 & 130 & 459 \\
\hline Dy161 & 754 & 843 & 710 & 436 & 2951 & 528 & 652 & 2816 \\
\hline Ho165 & 104 & 116 & 95.36 & 57.65 & 577 & 68.14 & 89.03 & 546 \\
\hline Er166 & 177 & 211 & 152 & 91.44 & 1421 & 112 & 144 & 1284 \\
\hline Tm169 & 16.64 & 21.69 & 13.36 & 8.53 & 189 & 10.47 & 12.82 & 175 \\
\hline
\end{tabular}




\begin{tabular}{|c|c|c|c|c|c|c|c|c|}
\hline Yb173 & 78.72 & 107 & 57.75 & 39.77 & 1167 & 48.03 & 56.68 & 1137 \\
\hline Lu175 & 6.87 & 9.04 & 4.33 & 3.18 & 122 & 3.92 & 4.34 & 123 \\
\hline $\mathrm{Hf} 178$ & 7.32 & 7.93 & 6 & 4.52 & 47.42 & 5.6 & 6.36 & 50.91 \\
\hline Ta181 & 116 & 236 & 133 & 121 & 325 & 142 & 177 & 346 \\
\hline $\mathrm{Pb} 206$ & 12.58 & 12.53 & 10.1 & 8.18 & 97.97 & 9.3 & 10.84 & 41.33 \\
\hline $\mathrm{Pb} 207$ & 4.38 & 4.24 & 3.75 & 4.46 & 14.57 & 4.4 & 4.54 & 7.05 \\
\hline Pb208 & 3.98 & 4.13 & 3.53 & 4.12 & 19.28 & 4.37 & 4.58 & 7.22 \\
\hline Th232 & 2.38 & 3.6 & 2.08 & 1.257 & 130 & 1.67 & 2.33 & 37.27 \\
\hline U238 & 33.36 & 29.29 & 27.57 & 17.38 & 106 & 22.86 & 27.37 & 63.74 \\
\hline
\end{tabular}


Table A 4 - ICP-MS analysis on titanite grains at the hornblende-garnet metatexite unit (Sample CGE-09D)

\begin{tabular}{|c|c|c|c|c|c|c|c|c|}
\hline \multicolumn{9}{|c|}{ Sample CGE-09D } \\
\hline $\mathrm{Li} 7$ & $<0.23$ & $<0.27$ & $<0.36$ & 0.37 & $<0.23$ & 8.31 & 12 & 0.59 \\
\hline $\mathrm{Mg} 24$ & 24.26 & 34.76 & 26.56 & 34.92 & 26.84 & 345 & 434 & 43.02 \\
\hline Al27 & 18141 & 15548 & 18233 & 17807 & 19666 & 171735 & 181193 & 16815 \\
\hline Si29 & 85647 & 92892 & 88410 & 92995 & 81112 & 217488 & 209644 & 113994 \\
\hline P31 & 32.15 & 71.58 & 37.5 & 56.14 & 46.34 & 47.29 & 40.08 & 63.61 \\
\hline $\mathrm{Ca} 42$ & 189881 & 183834 & 171540 & 169366 & 112647 & 117884 & 121888 & 157326 \\
\hline Ca44 & 192397 & 192397 & 192397 & 192397 & 192397 & 192397 & 192397 & 192397 \\
\hline Sc45 & 6.68 & 6.38 & 8.72 & 8.69 & 7.05 & 119 & 108 & 6.17 \\
\hline $\mathrm{Ti} 46$ & 145776 & 172651 & 157595 & 164787 & 169399 & 5519 & 7655 & 162844 \\
\hline Ti49 & 169049 & 196916 & 175065 & 175414 & 191860 & 6105 & 8296 & 192368 \\
\hline V51 & 1.416 & 1.53 & 1.62 & 2.23 & 1.62 & 4.64 & 8.71 & 2.18 \\
\hline Cr52 & 0.281 & 0.214 & $<0.21$ & 0.64 & 0.804 & 1.32 & 1.19 & 0.47 \\
\hline Mn55 & 47.71 & 66.58 & 49.52 & 69.81 & 63.95 & 863 & 804 & 88.83 \\
\hline Fe56 & 6977 & 9089 & 7376 & 6972 & 8939 & 180043 & 214177 & 8222 \\
\hline Co59 & 0.0151 & 0.0303 & $<0.015$ & 0.052 & 0.0079 & 2.53 & 3.69 & 0.045 \\
\hline Sr88 & 73.59 & 47.4 & 93.48 & 60.54 & 56.74 & 4009 & 2448 & 72.04 \\
\hline Y89 & 1887 & 1812 & 1612 & 2518 & 2155 & 3923 & 3821 & 2253 \\
\hline Zr91 & 25.37 & 73.23 & 33.19 & 68.67 & 54.14 & 226 & 114 & 77.59 \\
\hline $\mathrm{Nb93}$ & 4751 & 3562 & 4745 & 4224 & 3858 & 3.95 & 2.19 & 3616 \\
\hline Sn118 & 38.59 & 37.91 & 48.94 & 43.3 & 30.15 & 9.64 & 9.18 & 41.7 \\
\hline Sb121 & $<0.023$ & $<0.028$ & 0.057 & $<0.036$ & $<0.025$ & 0.079 & 0.093 & $<0.046$ \\
\hline $\mathrm{Ba} 137$ & 0.391 & 0.882 & 0.479 & 2.28 & 0.227 & 456 & 276 & 1.51 \\
\hline La139 & 14.1 & 64.81 & 20.53 & 66.82 & 36.21 & 62030 & 88288 & 53.8 \\
\hline Ce140 & 123 & 752 & 175 & 673 & 241 & 128617 & 172797 & 487 \\
\hline Pr141 & 27.66 & 104 & 40.4 & 107 & 66.37 & 15315 & 18841 & 112 \\
\hline $\mathrm{Nd} 143$ & 211 & 796 & 321 & 742 & 523 & 58789 & 65801 & 902 \\
\hline Sm147 & 156 & 459 & 200 & 413 & 324 & 6474 & 6071 & 542 \\
\hline Eu151 & 39.93 & 116 & 45.35 & 83.84 & 82.13 & 634 & 477 & 121 \\
\hline Gd157 & 243 & 541 & 284 & 529 & 475 & 3377 & 3092 & 693 \\
\hline Tb159 & 52.7 & 86.9 & 59.9 & 99.64 & 86.37 & 312 & 294 & 125 \\
\hline Dy 161 & 297 & 383 & 326 & 510 & 413 & 1031 & 1007 & 618 \\
\hline Ho165 & 41.69 & 45.57 & 46.43 & 72.91 & 50.97 & 103 & 101 & 81.51 \\
\hline Er166 & 68.52 & 70.96 & 78.5 & 136 & 77.96 & 153 & 144 & 134 \\
\hline Tm169 & 6.05 & 6.17 & 7.07 & 13.84 & 6.62 & 10.48 & 8.71 & 12.43 \\
\hline
\end{tabular}




\begin{tabular}{|c|c|c|c|c|c|c|c|c|}
\hline Yb173 & 29.59 & 29.27 & 31.89 & 70.64 & 30.47 & 44.95 & 36.27 & 58.74 \\
\hline Lu175 & 2.27 & 2.23 & 2.34 & 5.94 & 2.51 & 4.99 & 3.8 & 4.62 \\
\hline $\mathrm{Hf} 178$ & 2.38 & 6.16 & 3.35 & 6.18 & 4.2 & 3.84 & 3.13 & 6.24 \\
\hline Ta181 & 87.48 & 69.41 & 140 & 116 & 60.76 & 0.199 & 0.172 & 131 \\
\hline $\mathrm{Pb} 206$ & 6.53 & 11.69 & 8.67 & 9.62 & 8.55 & 667 & 329 & 11.75 \\
\hline $\mathrm{Pb} 207$ & 4.94 & 4.12 & 6.66 & 5.33 & 4.03 & 593 & 277 & 6.03 \\
\hline $\mathrm{Pb} 208$ & 5.04 & 3.83 & 6.48 & 5.62 & 4.16 & 775 & 474 & 5.42 \\
\hline Th232 & 0.415 & 3.43 & 1.174 & 3.72 & 1.92 & 5055 & 5898 & 2.69 \\
\hline U238 & 6.6 & 26.35 & 8.08 & 15.52 & 14.72 & 255 & 181 & 21.52 \\
\hline
\end{tabular}


Table A 5 - Summary of LA-ICP-MS U-Pb data on zircons

\begin{tabular}{|c|c|c|c|c|c|c|c|c|c|c|c|c|c|c|}
\hline \multirow{2}{*}{$\begin{array}{l}\text { grain/spot } \\
\text { position }\end{array}$} & \multicolumn{6}{|c|}{ Isotopic ratios } & \multirow{2}{*}{$\begin{array}{c}\text { Th } \\
\text { ppm }\end{array}$} & \multirow{2}{*}{$\begin{array}{c}\mathrm{U} \\
\mathrm{ppm}\end{array}$} & \multirow[t]{2}{*}{$\mathrm{Th} / \mathrm{U}$} & \multicolumn{4}{|c|}{ AGES (in Ma) } & \multirow{2}{*}{$\begin{array}{c}\text { Concordance }^{1} \\
\%\end{array}$} \\
\hline & ${ }^{207} \mathrm{~Pb} /{ }^{235} \mathrm{U}$ & $\sigma$ & ${ }^{206} \mathrm{~Pb} /{ }^{238} \mathrm{U}$ & $\sigma$ & ${ }^{207} \mathrm{~Pb} /{ }^{206} \mathrm{~Pb}$ & $\sigma$ & & & & ${ }^{206} \mathrm{~Pb} /{ }^{238} \mathrm{U}$ & $\sigma$ & ${ }^{207} \mathrm{~Pb} /{ }^{206} \mathrm{~Pb}$ & $\Sigma$ & \\
\hline 23.1 & 6.7012 & 0.0593 & 0.3789 & 0.0043 & 0.1281 & 0.0002 & 188.4 & 579.0 & 0.325 & 2.071 & 0.020 & 2.070 & 0.003 & 100 \\
\hline 19.2 & 6.6553 & 0.0636 & 0.3758 & 0.0044 & 0.1275 & 0.0004 & 58.8 & 65.9 & 0.893 & 2.056 & 0.021 & 2.061 & 0.006 & 100 \\
\hline 15.2 & 6.6263 & 0.0378 & 0.3757 & 0.0026 & 0.1278 & 0.0007 & 72.3 & 50.5 & 1.431 & 2.056 & 0.012 & 2.066 & 0.010 & 100 \\
\hline 13.2 & 6.6824 & 0.0434 & 0.3769 & 0.0028 & 0.1281 & 0.0009 & 25.2 & 20.9 & 1.201 & 2.062 & 0.013 & 2.069 & 0.012 & 100 \\
\hline 13.1 & 6.7001 & 0.0273 & 0.3796 & 0.0023 & 0.1285 & 0.0007 & 58.9 & 37.0 & 1.593 & 2.075 & 0.011 & 2.075 & 0.009 & 100 \\
\hline 12.1 & 6.7026 & 0.0337 & 0.3796 & 0.0028 & 0.1288 & 0.0006 & 68.9 & 41.6 & 1.655 & 2.074 & 0.013 & 2.079 & 0.009 & 100 \\
\hline 24.1 & 6.8258 & 0.0621 & 0.3815 & 0.0044 & 0.1285 & 0.0004 & 72.0 & 45.5 & 1.582 & 2.083 & 0.021 & 2.075 & 0.006 & 100 \\
\hline 19.1 & 6.8414 & 0.0676 & 0.3821 & 0.0045 & 0.1286 & 0.0005 & 94.9 & 57.0 & 1.6647 & 2.086 & 0.021 & 2.076 & 0.007 & 100 \\
\hline 25.1 & 6.7500 & 0.0613 & 0.3774 & 0.0043 & 0.1278 & 0.0003 & 201.3 & 131.0 & 1.537 & 2.064 & 0.020 & 2.066 & 0.004 & 100 \\
\hline 1.1 & 6.7687 & 0.2033 & 0.3832 & 0.0100 & 0.1293 & 0.0008 & 122.2 & 124.8 & 0.9795 & 2.091 & 0.047 & 2.086 & 0.010 & 100 \\
\hline 2.1 & 6.7054 & 0.2010 & 0.3747 & 0.0098 & 0.1273 & 0.0008 & 15.2 & 26.6 & 0.569 & 2.052 & 0.046 & 2.059 & 0.010 & 100 \\
\hline 3.1 & 6.7439 & 0.2084 & 0.3791 & 0.0103 & 0.1289 & 0.0007 & 185.8 & 517.3 & 0.359 & 2.072 & 0.048 & 2.080 & 0.009 & 100 \\
\hline 4.1 & 6.6064 & 0.1978 & 0.3754 & 0.0098 & 0.1275 & 0.0007 & 169.3 & 229.5 & 0.738 & 2.055 & 0.046 & 2.062 & 0.009 & 100 \\
\hline 6.1 & 6.4553 & 0.1945 & 0.3751 & 0.0098 & 0.1263 & 0.0008 & 66.8 & 47.4 & 1.408 & 2.053 & 0.046 & 2.045 & 0.011 & 100 \\
\hline 7.1 & 6.5027 & 0.1941 & 0.3736 & 0.0097 & 0.1269 & 0.0008 & 46.2 & 47.1 & 0.981 & 2.046 & 0.046 & 2.054 & 0.010 & 100 \\
\hline 9.1 & 6.7643 & 0.2016 & 0.3815 & 0.0099 & 0.1282 & 0.0007 & 105.2 & 137.8 & 0.763 & 2.083 & 0.046 & 2.071 & 0.010 & 101 \\
\hline 11.1 & 6.4829 & 0.0298 & 0.3750 & 0.0023 & 0.1267 & 0.0007 & 41.3 & 32.8 & 1.2586 & 2.053 & 0.011 & 2.051 & 0.010 & 100 \\
\hline 16.2 & 6.4674 & 0.0268 & 0.3722 & 0.0024 & 0.1261 & 0.0006 & 176.1 & 208.1 & 0.846 & 2.040 & 0.011 & 2.042 & 0.008 & 100 \\
\hline 18.1 & 6.3536 & 0.0372 & 0.3690 & 0.0028 & 0.1270 & 0.0007 & 123.5 & 104.5 & 1.182 & 2.025 & 0.013 & 2.055 & 0.009 & 99 \\
\hline 19.3 & 6.4567 & 0.0745 & 0.3724 & 0.0049 & 0.1264 & 0.0003 & 126.2 & 533.2 & 0.237 & 2.041 & 0.023 & 2.047 & 0.004 & 100 \\
\hline 21.1 & 6.5165 & 0.0658 & 0.3733 & 0.0046 & 0.1269 & 0.0004 & 49.3 & 56.7 & 0.870 & 2.045 & 0.022 & 2.054 & 0.006 & 100 \\
\hline 4.2 & 6.3345 & 0.1889 & 0.3571 & 0.0093 & 0.1247 & 0.0007 & 168.6 & 800.9 & 0.211 & 1.969 & 0.044 & 2.023 & 0.010 & 97 \\
\hline 5.1 & 6.0534 & 0.1802 & 0.3456 & 0.0090 & 0.1259 & 0.0007 & 150.1 & 879.8 & 0.171 & 1.913 & 0.043 & 2.039 & 0.009 & 94 \\
\hline 26.1 & 6.2686 & 0.0578 & 0.3663 & 0.0042 & 0.1241 & 0.0005 & 48.9 & 44.4 & 1.101 & 2.012 & 0.020 & 2.015 & 0.007 & 100 \\
\hline 8.1 & 7.0235 & 0.2211 & 0.3903 & 0.0107 & 0.1325 & 0.0009 & 84.8 & 583.9 & 0.145 & 2.124 & 0.049 & 2.128 & 0.011 & 100 \\
\hline 17.1 & 6.8375 & 0.0258 & 0.3815 & 0.0025 & 0.1292 & 0.0007 & 62.5 & 49.3 & 1.267 & 2.083 & 0.012 & 2.085 & 0.009 & 100 \\
\hline 22.1 & 6.9573 & 0.0724 & 0.3851 & 0.0047 & 0.1301 & 0.0003 & 66.6 & 59.2 & 1.126 & 2.100 & 0.022 & 2.096 & 0.005 & 100 \\
\hline 15.1 & 6.8399 & 0.0274 & 0.3806 & 0.0024 & 0.1294 & 0.0006 & 94.5 & 62.9 & 1.503 & 2.079 & 0.011 & 2.087 & 0.008 & 100 \\
\hline 6.2 & 5.7253 & 0.1797 & 0.3360 & 0.0094 & 0.1243 & 0.0007 & 183.1 & 227.7 & 0.804 & 1.867 & 0.045 & 2.018 & 0.009 & 93 \\
\hline 21.2 & 5.6802 & 0.0511 & 0.3288 & 0.0038 & 0.1244 & 0.0003 & 190.3 & 1158.5 & 0.164 & 1.833 & 0.018 & 2.018 & 0.004 & 91 \\
\hline 10.1 & 5.7027 & 0.1707 & 0.3311 & 0.0086 & 0.1248 & 0.0007 & 84.7 & 103.2 & 0.821 & 1.844 & 0.042 & 2.025 & 0.010 & 91 \\
\hline 16.1 & 7.1269 & 0.0344 & 0.3769 & 0.0026 & 0.1282 & 0.0007 & 113.0 & 73.0 & 1.547 & 2.062 & 0.012 & 2.072 & 0.009 & 100 \\
\hline 14.1 & 6.9466 & 0.0281 & 0.3855 & 0.0023 & 0.1298 & 0.0006 & 152.2 & 99.5 & 1.529 & 2.102 & 0.011 & 2.092 & 0.008 & 100 \\
\hline 20.1 & 7.3796 & 0.0808 & 0.4124 & 0.0051 & 0.1302 & 0.0005 & 39.3 & 35.8 & 1.099 & 2.226 & 0.023 & 2.098 & 0.007 & 106 \\
\hline
\end{tabular}




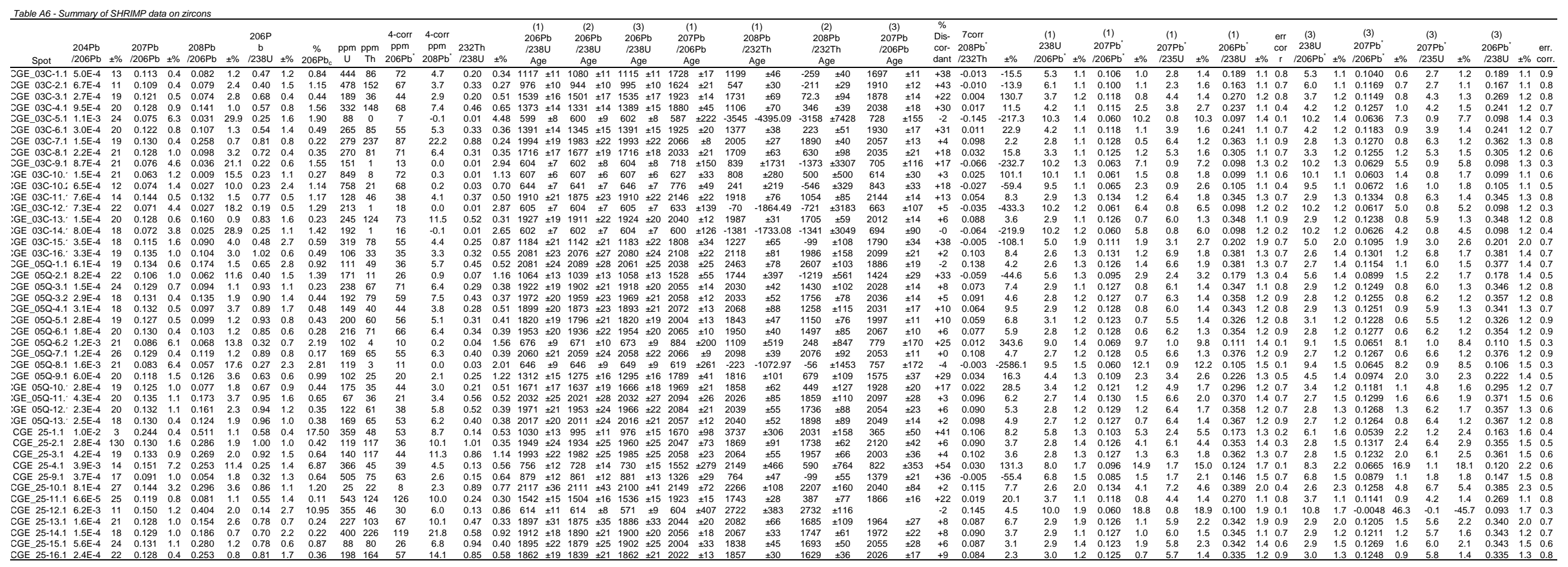

ate the common and radiogenic portions, respectively.

above errors but reauired when
oorrected using measured $204 \mathrm{~Pb}$.

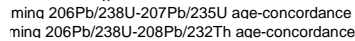


Table A7-Surmary of SHRMP data on titanite crystals

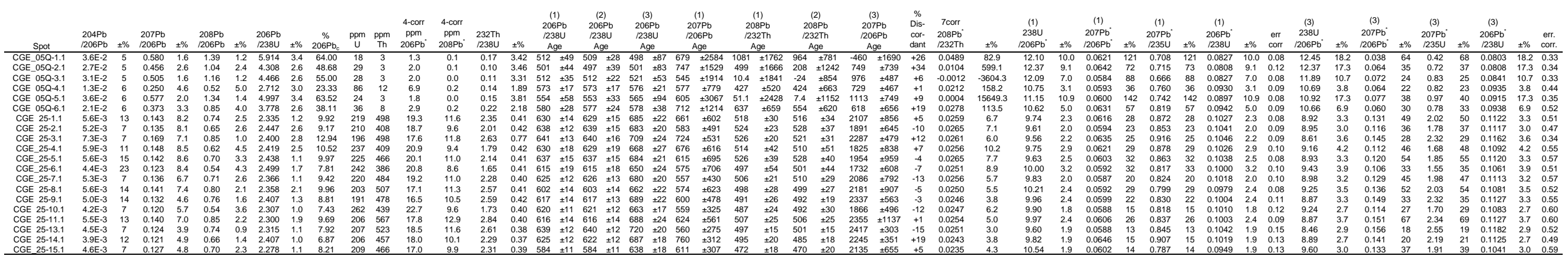

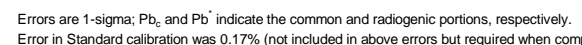

comparina datat from different mountss.

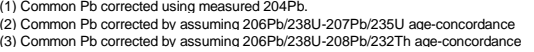


Table A8 - Summary of SHRIMPIle data on zircons crystals from sample TPR-40

\begin{tabular}{|c|c|c|c|c|c|c|c|c|c|c|c|c|}
\hline Spot ID & CL response & ${ }^{204} \mathrm{~Pb}$ & $\mathrm{U}(\mathrm{ppm})$ & Th (ppm) & $\mathrm{Th} / \mathrm{U}$ & ${ }^{206} \mathrm{~Pb} /{ }^{238} \mathrm{U}$ & 2SE (\%) & ${ }^{207} \mathrm{~Pb} /{ }^{235} \mathrm{U}$ & 2SE (\%) & ${ }^{207} \mathrm{~Pb} /{ }^{206} \mathrm{~Pb}$ & 2 SE $(\%)$ & ${ }^{206} \mathrm{~Pb} /{ }^{238} \mathrm{U}$ Age \\
\hline TPR40-1.2 & bright & 0.162 & 167.6 & 75.0 & 0.447 & 0.3929 & 3.2 & 6.97 & 3.3 & 0.1287 & 0.9 & 2136.1 \\
\hline TPR40-7.1 & bright & -0.115 & 55.3 & 50.8 & 0.919 & 0.3653 & 3.0 & 6.50 & 3.1 & 0.1290 & 0.5 & 2007.2 \\
\hline TPR40-8.1 & bright & 0.043 & 197.5 & 266.8 & 1.351 & 0.3994 & 3.1 & 7.04 & 3.2 & 0.1278 & 0.6 & 2166.1 \\
\hline TPR40-9.1 & bright & 0.098 & 99.0 & 107.5 & 1.086 & 0.3992 & 3.2 & 7.16 & 3.3 & 0.1302 & 0.8 & 2165.3 \\
\hline TPR40-10.1 & bright & -0.056 & 57.8 & 78.5 & 1.357 & 0.3884 & 3.2 & 6.89 & 3.2 & 0.1287 & 0.4 & 2115.2 \\
\hline TPR40-13.1 & bright & -0.016 & 225.4 & 207.6 & 0.921 & 0.3585 & 3.1 & 6.37 & 3.1 & 0.1289 & 0.5 & 1975.0 \\
\hline TPR40-14.1 & bright & 0.000 & 37.1 & 35.1 & 0.946 & 0.3751 & 3.4 & 6.49 & 3.5 & 0.1255 & 1.0 & 2053.2 \\
\hline TPR40-1.1 & dark & 0.106 & 1163.0 & 164.4 & 0.141 & 0.2501 & 3.2 & 4.04 & 3.2 & 0.1170 & 0.3 & 1439.1 \\
\hline TPR40-2.1 & dark & 0.124 & 1462.3 & 445.4 & 0.305 & 0.1765 & 3.0 & 2.67 & 3.0 & 0.1097 & 0.3 & 1047.7 \\
\hline TPR40-3.1 & dark & 0.067 & 1083.1 & 388.6 & 0.359 & 0.2062 & 3.1 & 3.17 & 3.1 & 0.1116 & 0.3 & 1208.6 \\
\hline TPR40-4.1 & dark & 0.062 & 1102.7 & 185.4 & 0.168 & 0.2488 & 3.0 & 4.03 & 3.0 & 0.1175 & 0.2 & 1432.4 \\
\hline TPR40-5.1 & dark & 0.112 & 1593.4 & 561.2 & 0.352 & 0.1741 & 3.0 & 2.38 & 3.0 & 0.0993 & 0.3 & 1034.8 \\
\hline TPR40-6. 1 & dark & 0.042 & 1695.9 & 347.5 & 0.205 & 0.1880 & 3.1 & 2.63 & 3.1 & 0.1015 & 0.4 & 1110.3 \\
\hline TPR40-8.2 & dark & 0.101 & 2109.4 & 240.1 & 0.114 & 0.1695 & 3.0 & 2.41 & 3.0 & 0.1031 & 0.5 & 1009.6 \\
\hline TPR40-11.1 & dark & 0.007 & 1504.0 & 235.3 & 0.156 & 0.2635 & 3.0 & 4.23 & 3.0 & 0.1165 & 0.2 & 1507.5 \\
\hline TPR40-12.1 & dark & 0.056 & 1923.5 & 232.7 & 0.121 & 0.2345 & 3.0 & 3.55 & 3.0 & 0.1100 & 0.4 & 1357.8 \\
\hline TPR40-15.1 & dark & 0.105 & 789.5 & 395.8 & 0.501 & 0.2391 & 3.0 & 3.81 & 3.0 & 0.1155 & 0.3 & 1382.2 \\
\hline
\end{tabular}




\begin{tabular}{cccc}
\hline 1SE & ${ }^{207} \mathrm{~Pb} /{ }^{206} \mathrm{~Pb}$ Age & 1SE & Discordance $(\%)$ \\
\hline 59 & 2080.2 & 26.0 & 6 \\
53 & 2047.2 & 77.1 & -3 \\
57 & 2107.4 & 27.3 & 4 \\
59 & 2130.0 & 32.9 & -6 \\
58 & 2064.6 & 19.5 & -4 \\
52 & 1971.0 & 15.3 & -2 \\
59 & 1866.4 & 41.0 & -1 \\
41 & 1855.6 & 8.3 & 28 \\
29 & 1756.2 & 20.5 & 45 \\
34 & 1658.1 & 11.2 & 37 \\
39 & 1975.2 & 7.1 & 28 \\
29 & 1416.8 & 18.4 & 39 \\
31 & 1659.4 & 8.8 & 36 \\
28 & 1612.1 & 11.0 & 43 \\
41 & 1903.7 & 5.6 & 23 \\
37 & 1767.0 & 8.4 & 27 \\
37 & 1218.0 & 21.5 & 30 \\
\hline
\end{tabular}




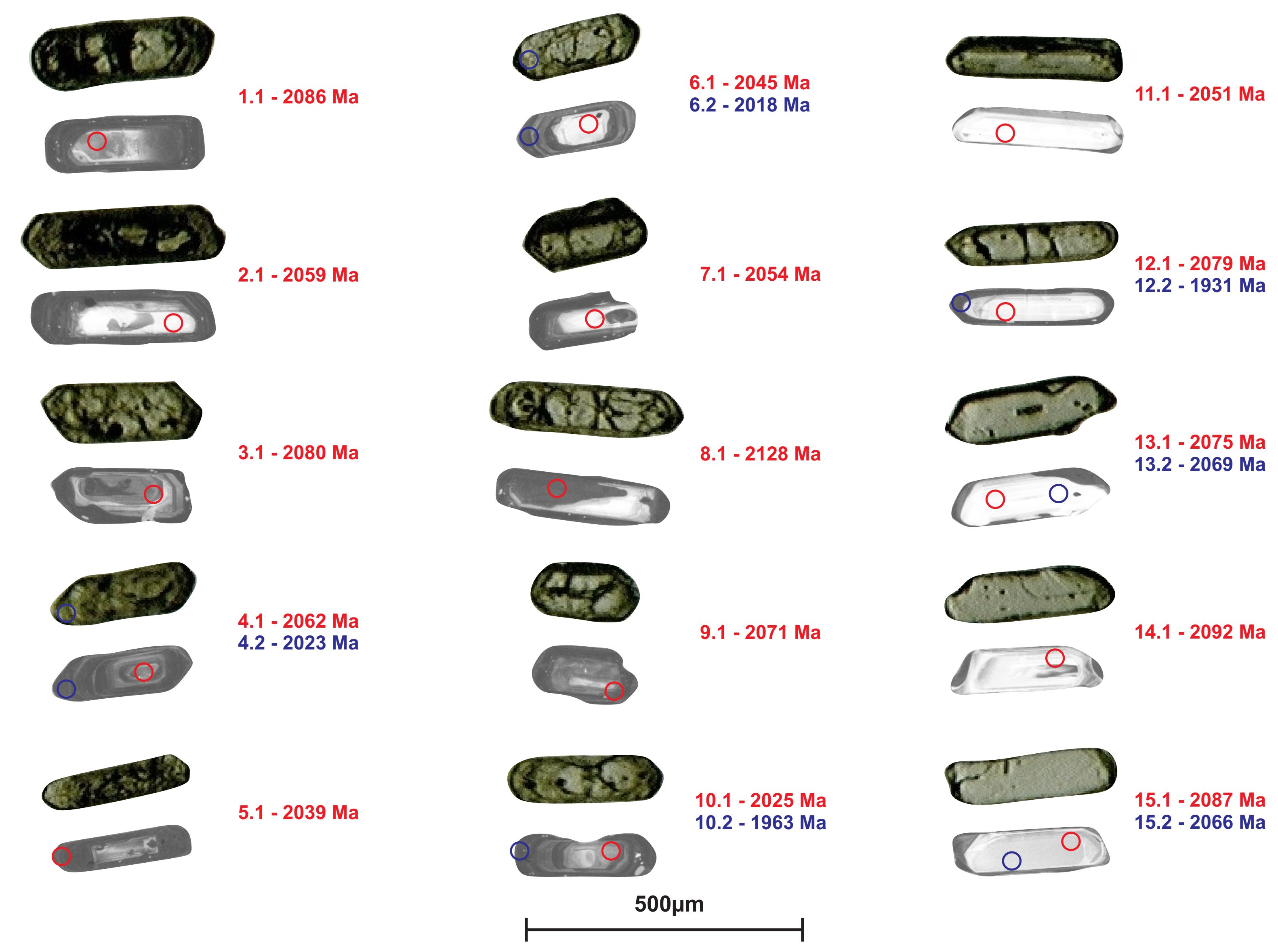

Cathodoluminescence (CL) image along with transmitted light image of U-Pb analysis in zircon at LA-MC-ICP-MS. Spot size of 30 $\mu m$. Sample from the Meta-syenogranite unit (ARE-04). Ages 206/207Pb for each spot are reported. 
16.1 - $2072 \mathrm{Ma}$

16.2 - $2042 \mathrm{Ma}$

17.1 - $2085 \mathrm{Ma}$
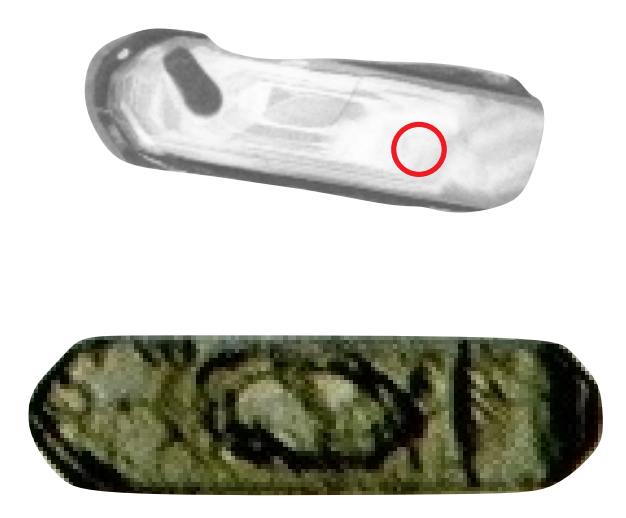

O
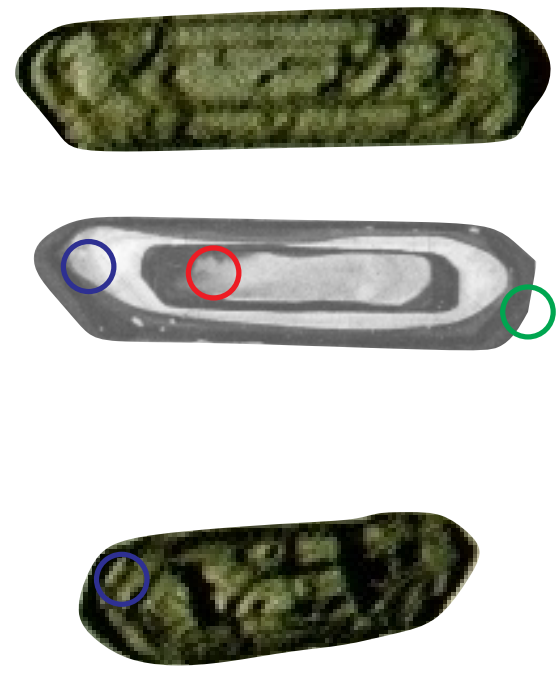

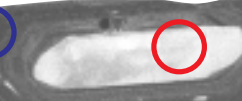

18.1 - $2055 \mathrm{Ma}$

19.1 - $2076 \mathrm{Ma}$

19.2 - $2061 \mathrm{Ma}$ 19.3 - $2047 \mathrm{Ma}$

20.1 - $2098 \mathrm{Ma}$ 20.2 - $1810 \mathrm{Ma}$

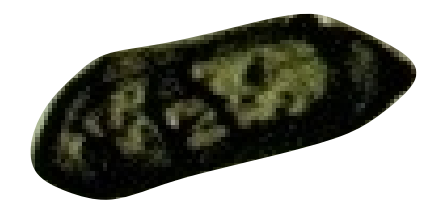

21.1 - $2054 \mathrm{Ma}$ 21.2 - $2018 \mathrm{Ma}$

22.1 - $2096 \mathrm{Ma}$

22.2 - $1886 \mathrm{Ma}$

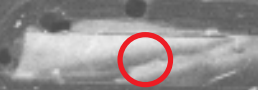
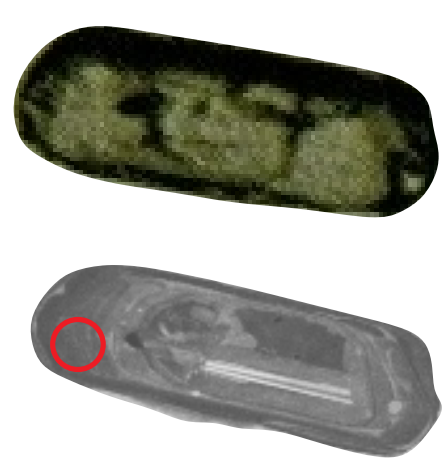

23.1 - $2070 \mathrm{Ma}$

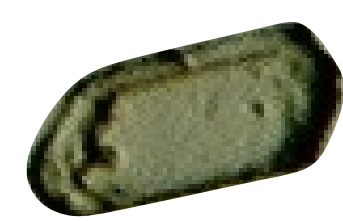

26.1 - $2015 \mathrm{Ma}$
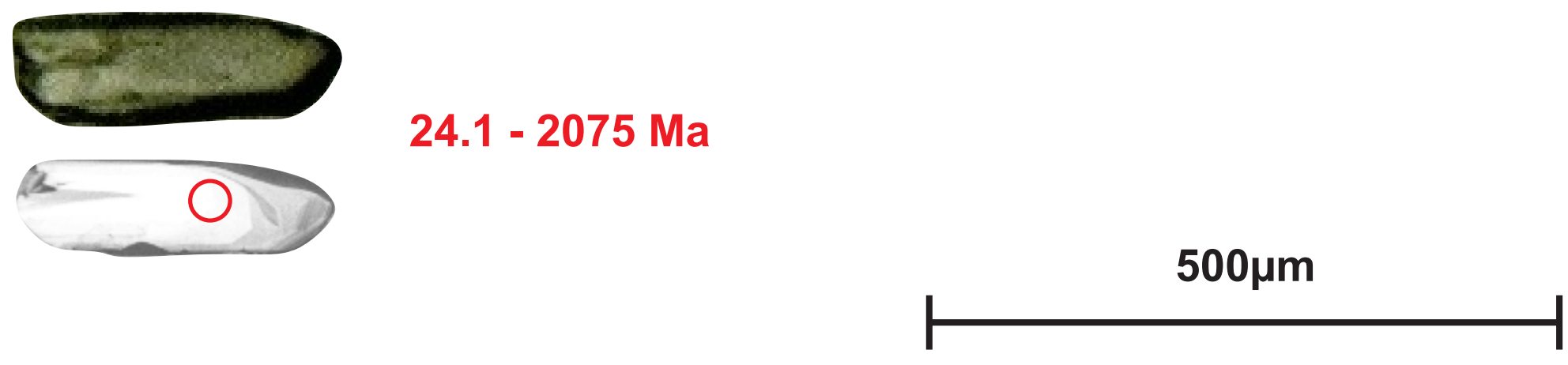

24.1 - $2075 \mathrm{Ma}$

25.1 - $2066 \mathrm{Ma}$
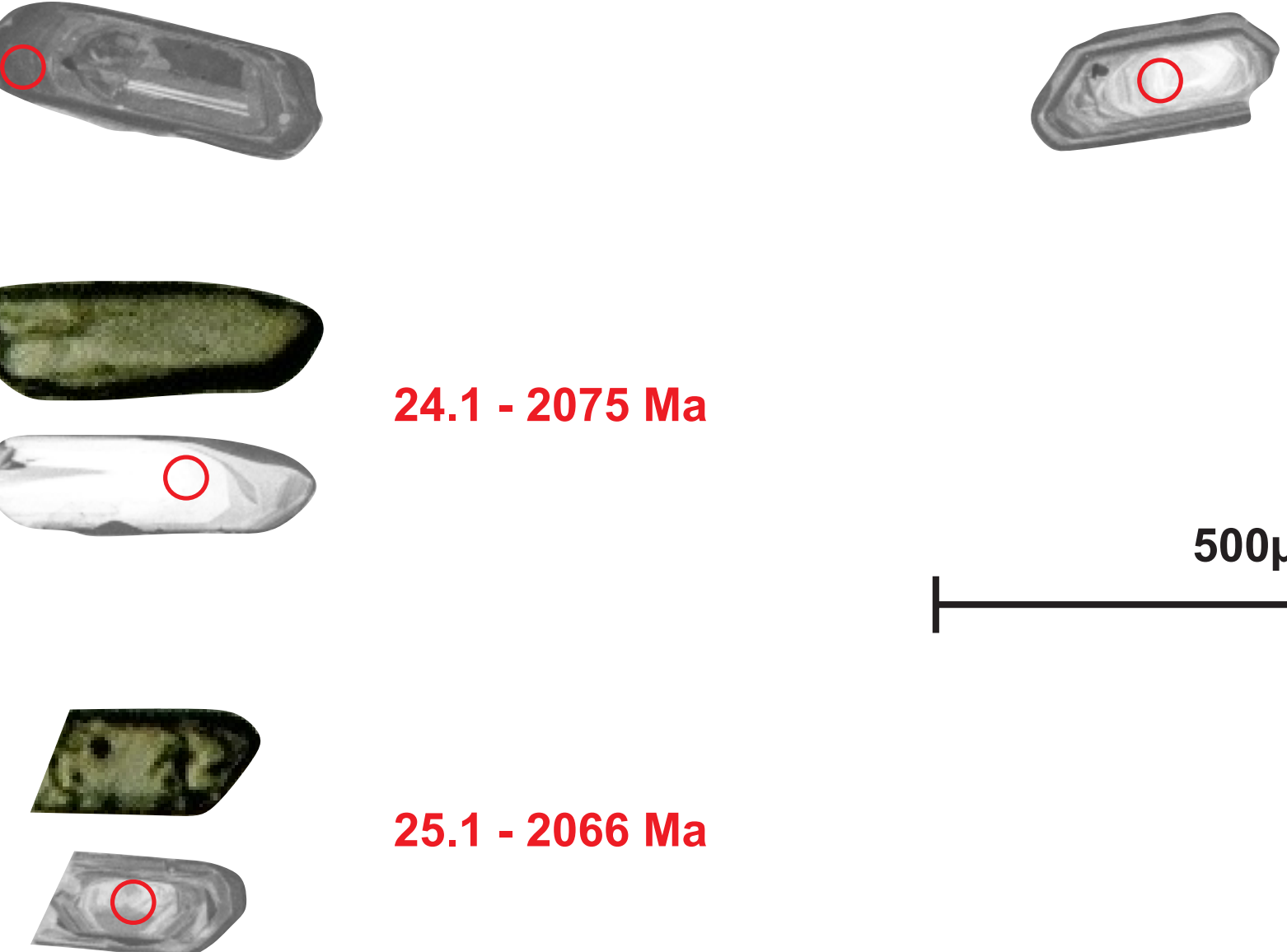

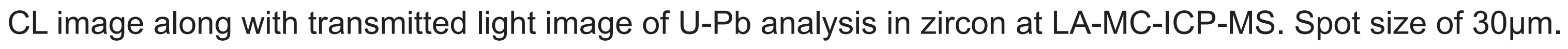

Sample from the Meta-syenogranite unit (ARE-04). Ages 206/207Pb for each spot are reported. 
$1.1-1670 \mathrm{Ma}$
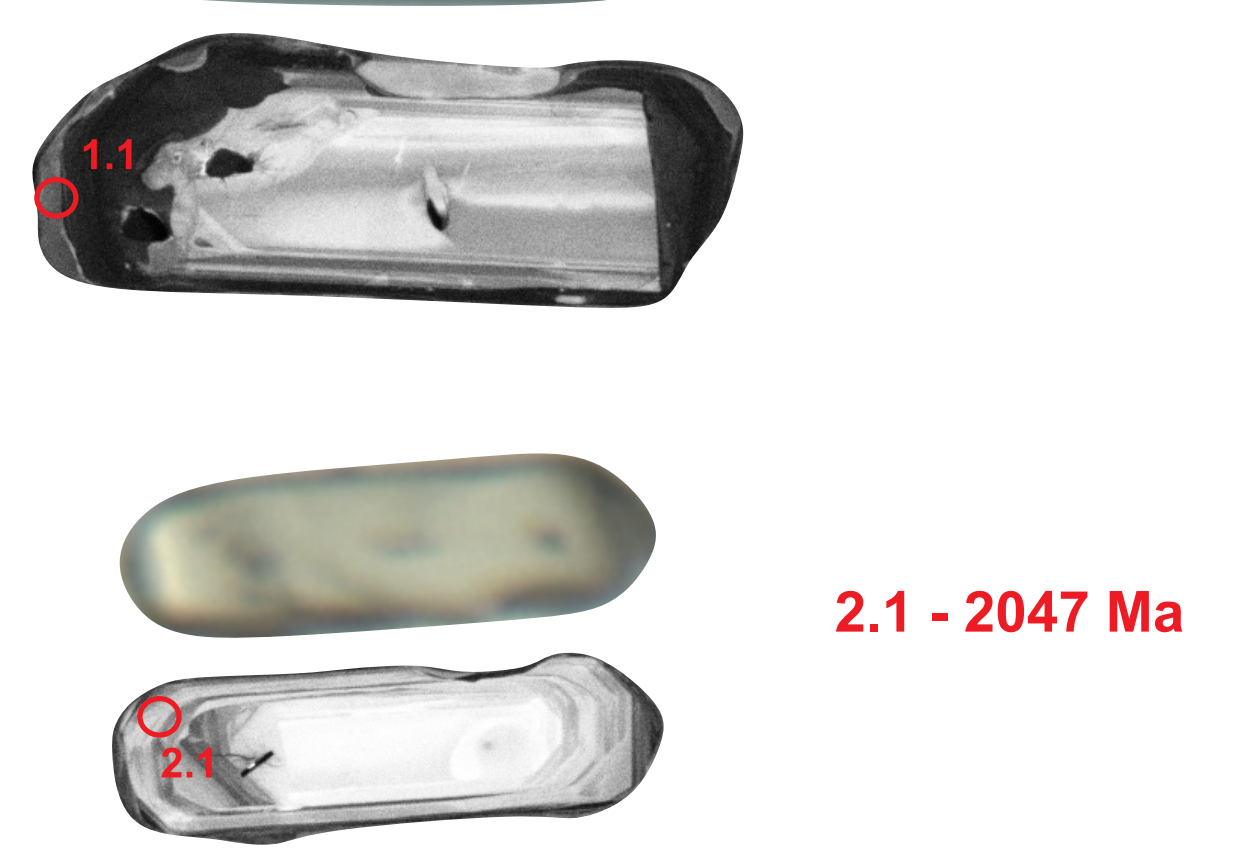

2.1 - $2047 \mathrm{Ma}$
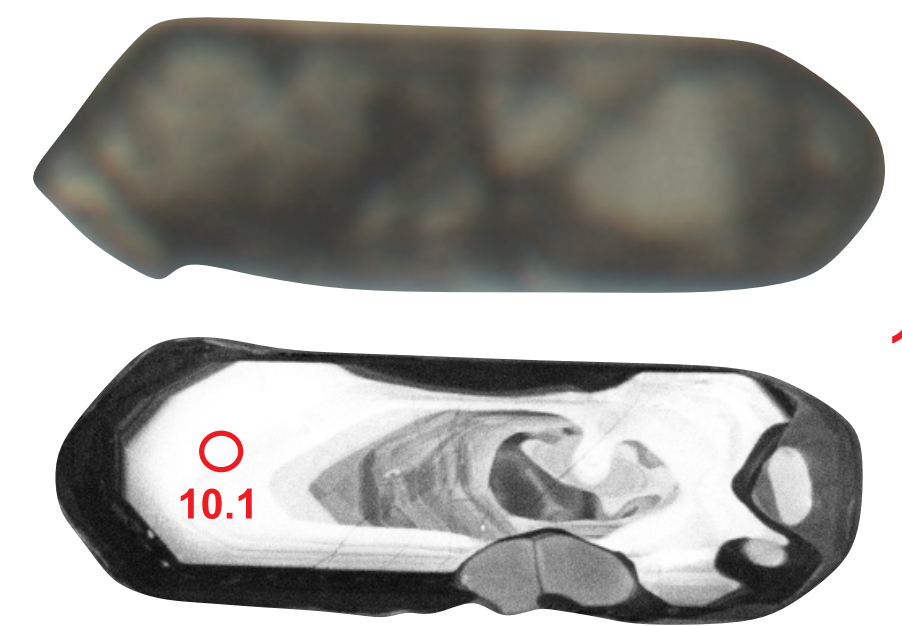

10.1 - $2149 \mathrm{Ma}$

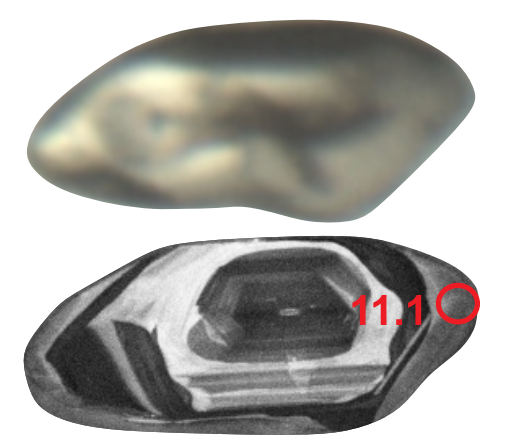

11.1 - $2069 \mathrm{Ma}$

3.1 - $2058 \mathrm{Ma}$

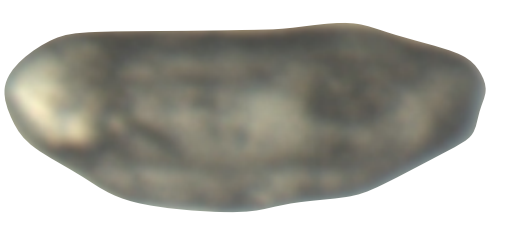

4.1 - 1552Ma

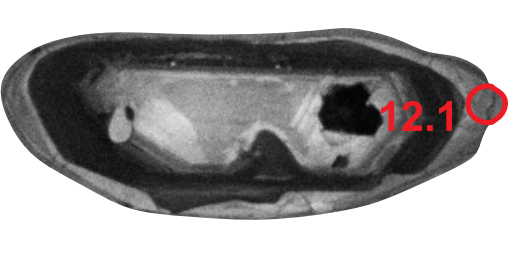

12.1 - $604 \mathrm{Ma}$
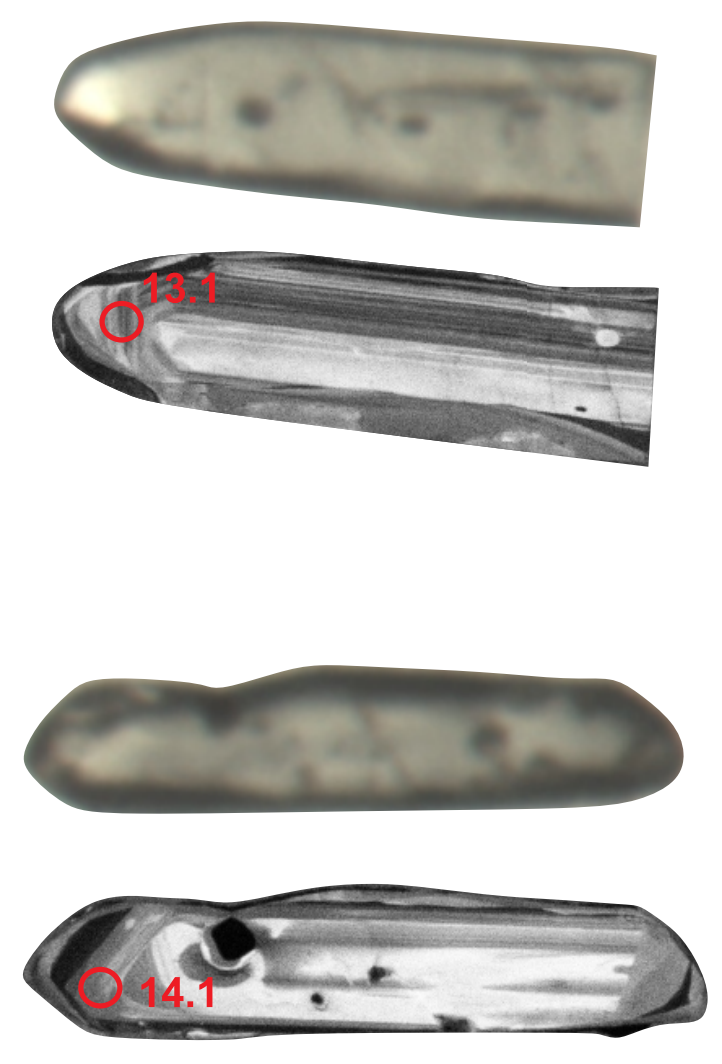

13.1 - $2044 \mathrm{Ma}$

14.1 - $2056 \mathrm{Ma}$ 15.1 - $2004 \mathrm{Ma}$
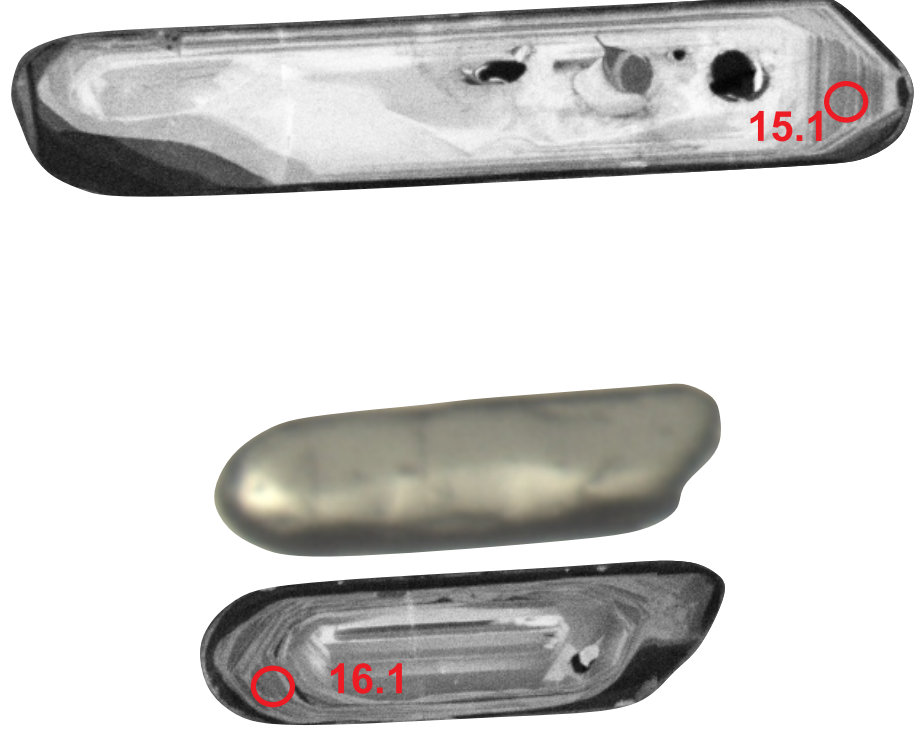

16.1 - $2022 \mathrm{Ma}$

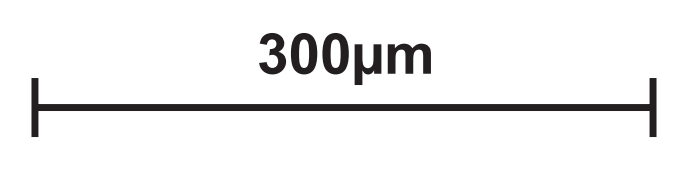

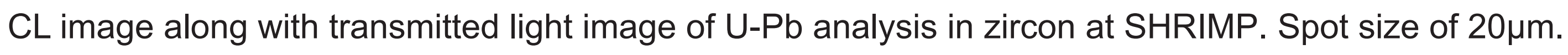
Sample from the Meta-syenogranite unit (CGE-25). Ages 206/207Pb for each spot are reported. 


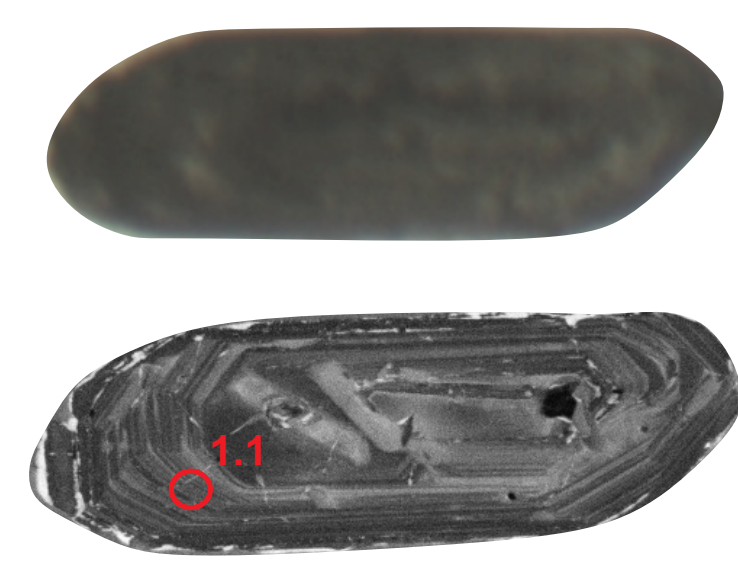

1.1 - $1117 \mathrm{Ma}$

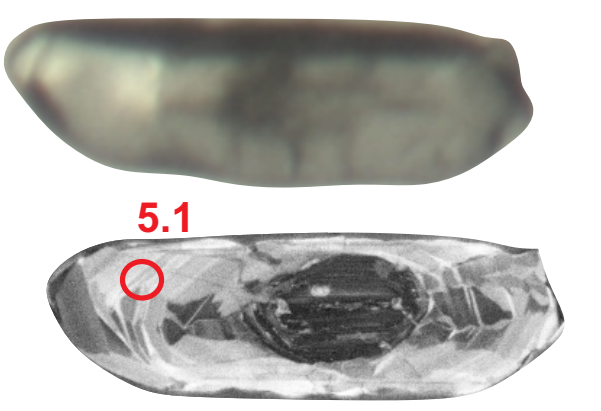

5.1 - $599 \mathrm{Ma}$

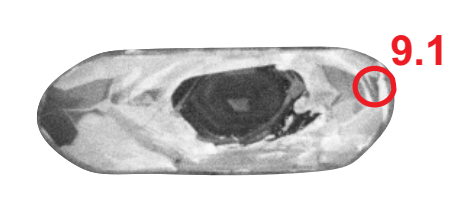

6.1 - $1391 \mathrm{Ma}$

2.1 - $976 \mathrm{Ma}$
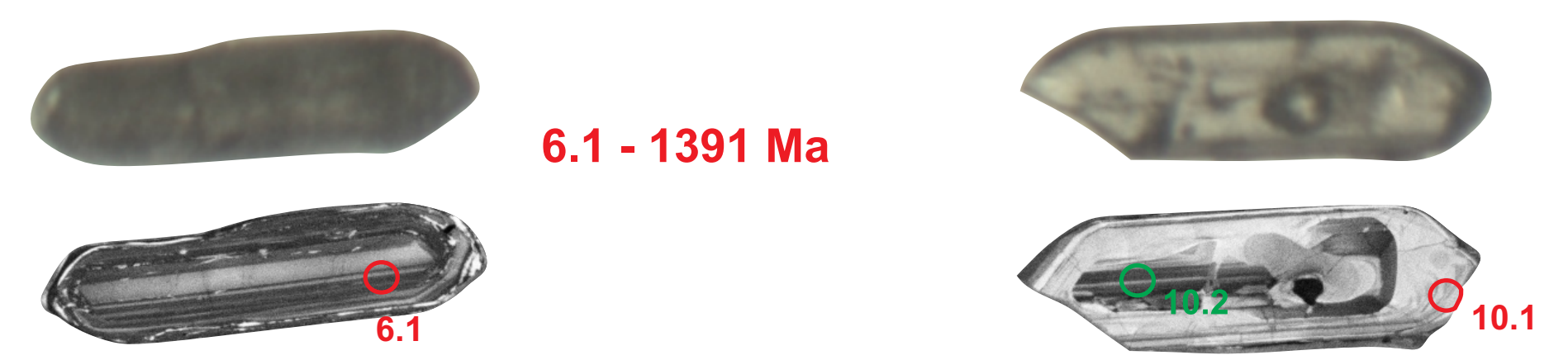

$10.1-607 \mathrm{Ma}$

10.2 - $644 \mathrm{Ma}$
$3.1-1539 \mathrm{Ma}$
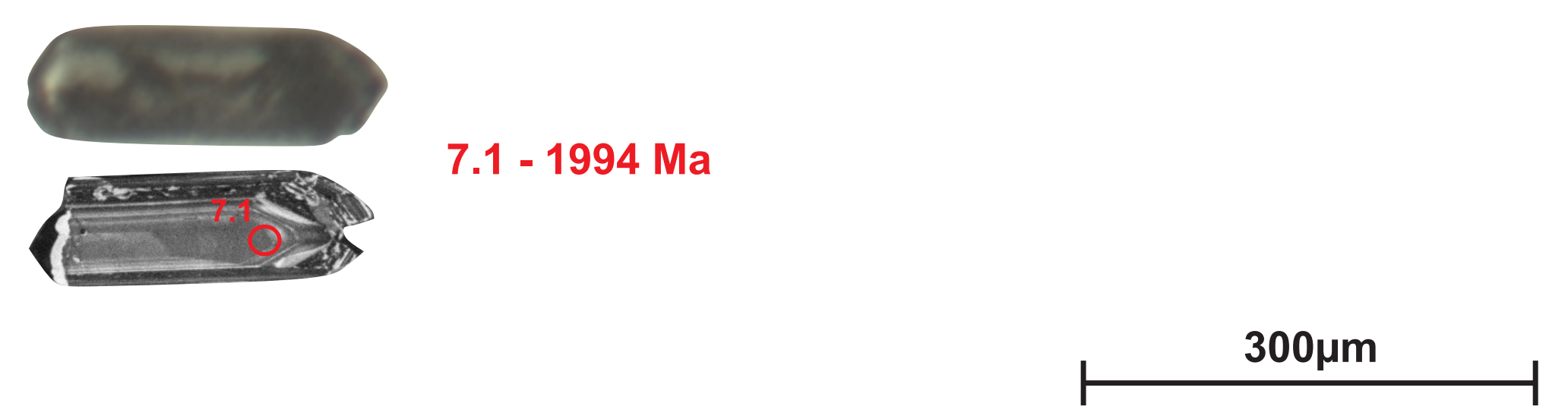

4.1 - 1373Ma

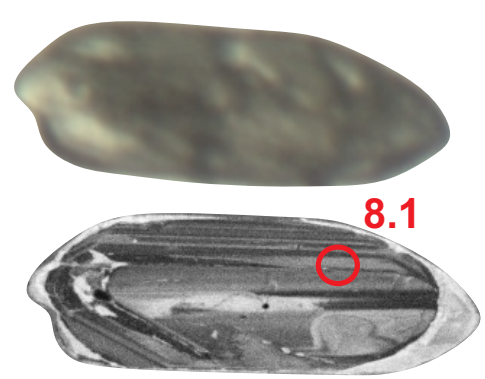

8.1 - $1716 \mathrm{Ma}$

CL image along with transmitted light image of U-Pb analysis in zircon at SHRIMP. Spot size of $20 \mu \mathrm{m}$. Sample from the Biotite diatexite unit (CGE-03Zr). Ages 206Pb/238U for each spot are reported. 


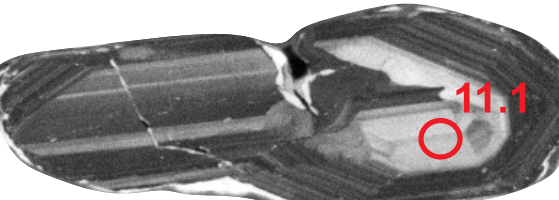

$12.1-605 \mathrm{Ma}$

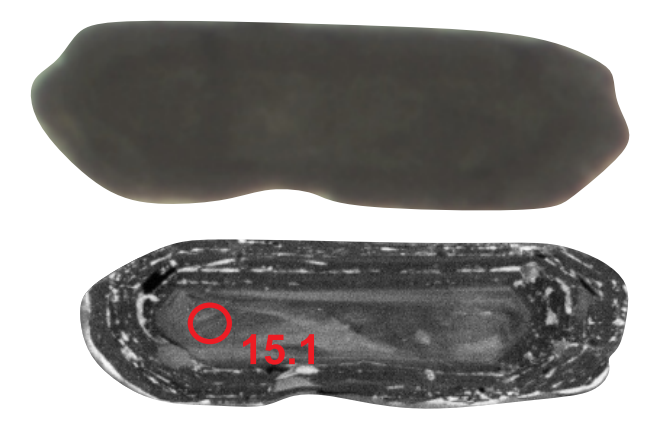

$15.1-1184 \mathrm{Ma}$

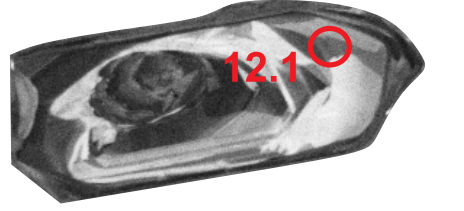

$12.1-605$ Ma

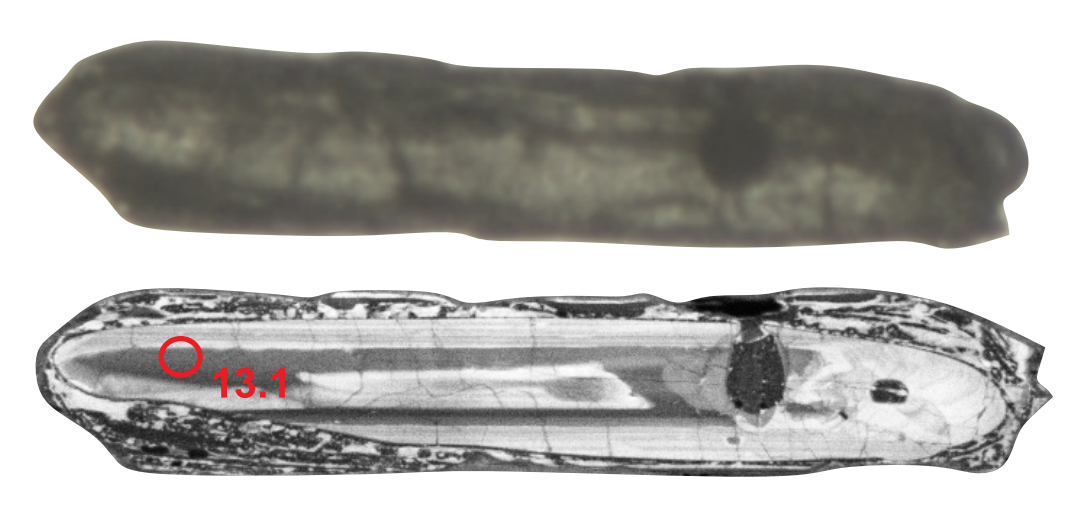

13.1 - $1927 \mathrm{Ma}$
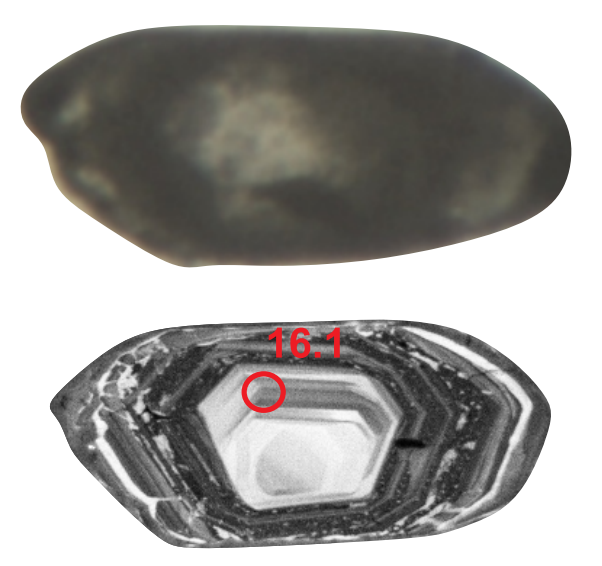

$16.1-2081 \mathrm{Ma}$

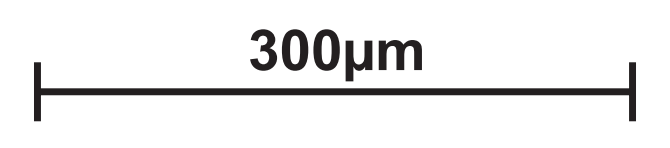

$\mathrm{CL}$ image along with transmitted light image of U-Pb analysis in zircon at SHRIMP. Spot size of $20 \mu \mathrm{m}$. Sample from the Biotite diatexite unit (CGE-03Zr). Ages 206Pb/238U for each spot are reported. 

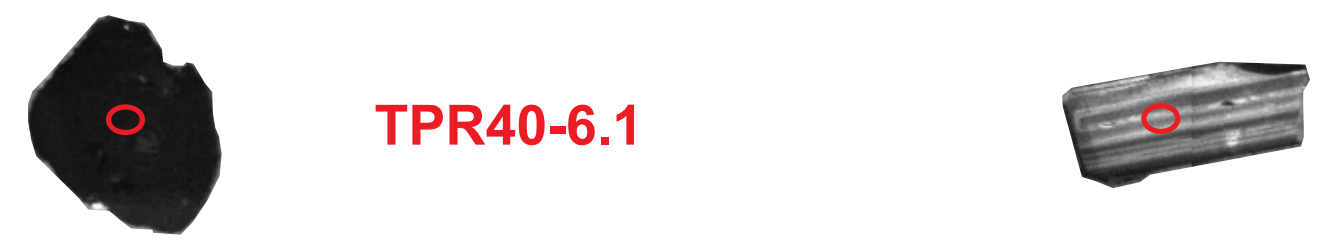

TPR40-10.1

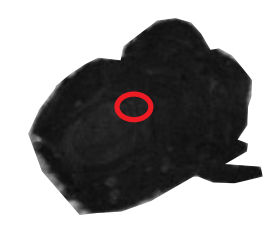

TPR40-3.1
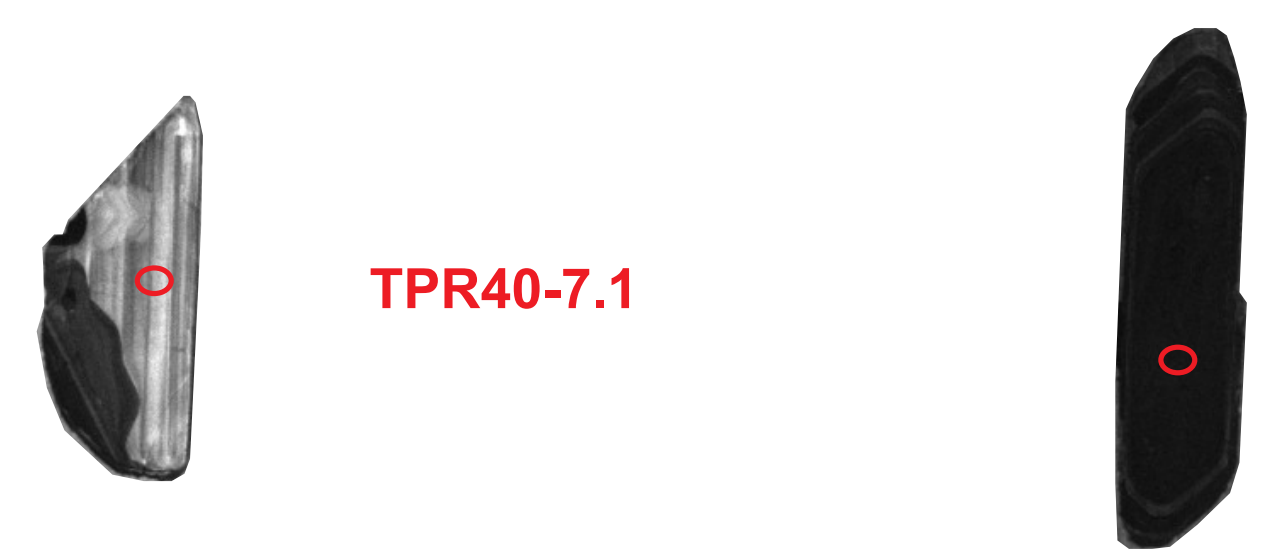

TPR40-11.1

TPR40-7.1

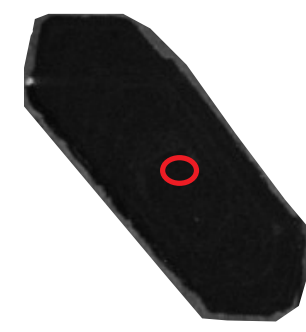

TPR40-12.1 


\section{Geological Map - Alfenas and Areado regions}

Author: Eduardo Lopes Julião. Contributors: Renato de Moraes, Rafael da Motta

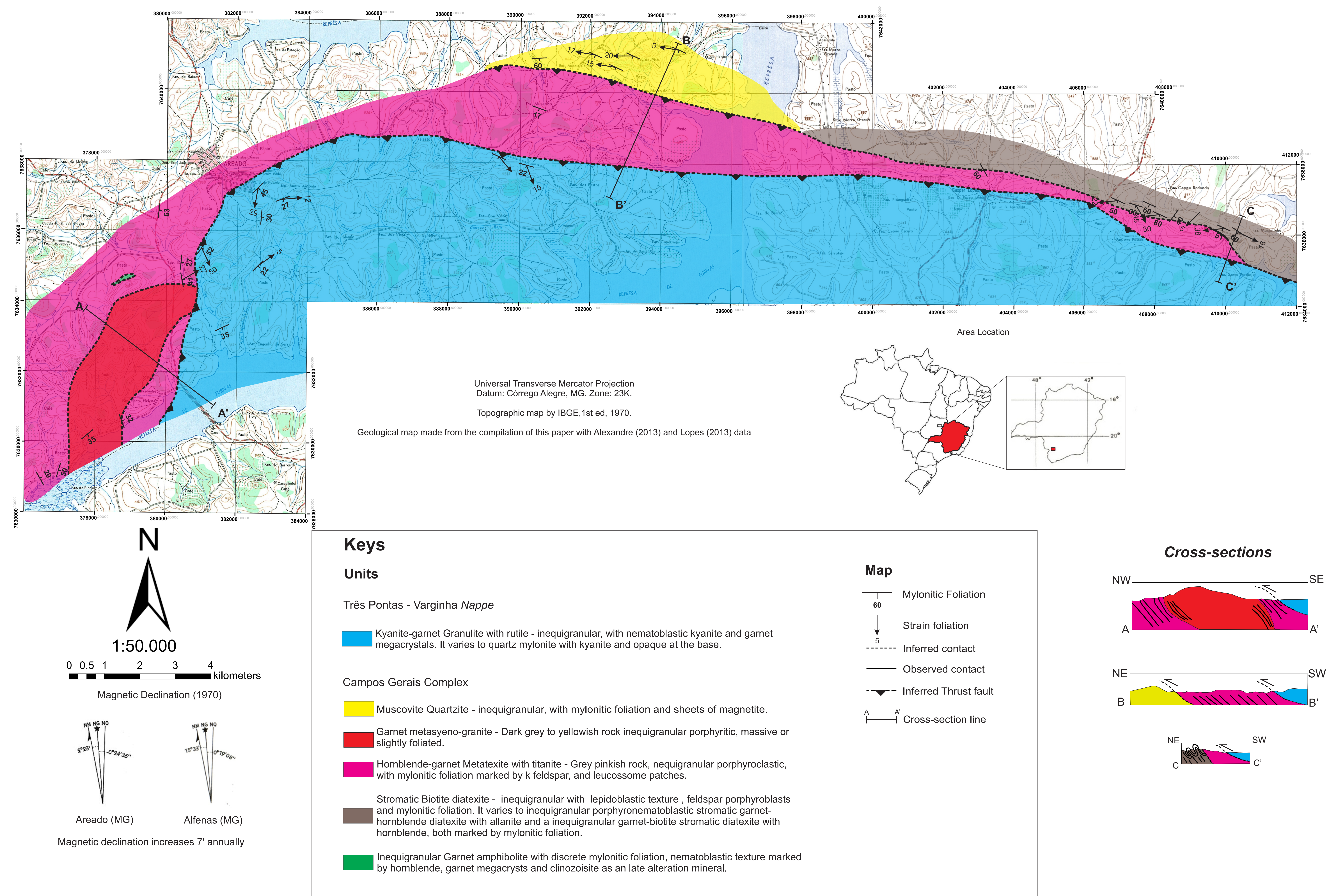

